UNIVERSIDADE DE SÃO PAULO

INSTITUTO DE GEOCIENCIAS

\title{
ESTUDO MACRO E MICROMORFOLÓGICO DE SEQÜENNCIA DE SOLOS EM MICROBACIA HIDROGRÁFICA NO NÚCLEO CUNHA-INDAIÁ NO PARQUE ESTADUAL DA SERRA DO MAR - SP
}

\author{
Débora Ayumi Ishida
}

Orientadora: Profa. Dra. Maria Cristina Motta de Toledo

\author{
DISSERTAÇÃO DE MESTRADO \\ Programa de Pós-Graduação em Geoquímica e Geotectônica
}

SÃO PAULO

2005 


\title{
UNIVERSIDADE DE SÃO PAULO \\ INSTITUTO DE GEOCIÊNCIAS
}

\section{ESTUDO MACRO E MICROMORFOLÓGICO DE SEQÜÊNCIA DE SOLOS EM MICROBACIA HIDROGRÁFICA NO NÚCLEO CUNHA- INDAIÁ NO PARQUE ESTADUAL DA SERRA DO MAR - SP}

\author{
DÉBORA AYUMI ISHIDA
}

Orientadora: Prof ${ }^{a}$. Dr ${ }^{\mathrm{a}}$. Maria Cristina Motta de Toledo

DISSERTAÇÃO DE MESTRADO

COMISSÃO JULGADORA

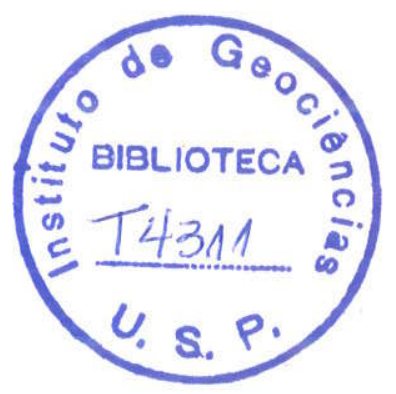

Nome

Presidente: $\quad \operatorname{Prof}^{\underline{a}}$. Dr ${ }^{a}$. Maria Cristina Motta de Toledo

Examinadores: Prof ${ }^{\mathrm{a}}$. Dr ${ }^{\mathrm{a}}$. Célia Regina Montes

Prof ${ }^{a}$. Dr ${ }^{a}$. Maria Teresa de Nóbrega

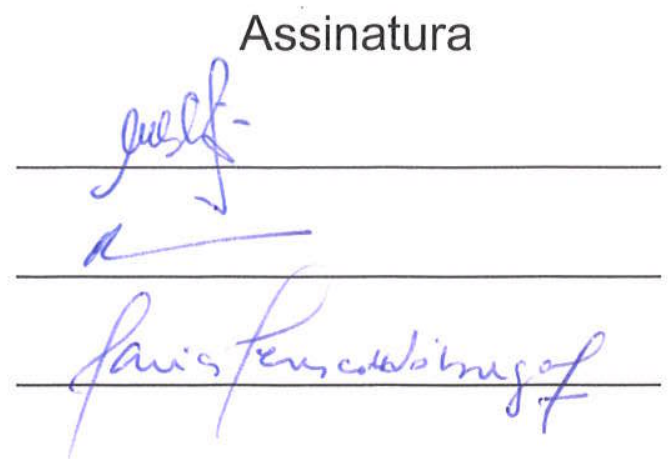

SÃO PAULO

2005 


\author{
UNIVERSIDADE DE SÃO PAULO \\ INSTITUTO DE GEOCIÊNCIAS
}

\title{
ESTUDO MACRO E MICROMORFOLÓGICO DE SEQÜÊNCIA DE SOLOS EM MICROBACIA HIDROGRÁFICA NO NÚCLEO CUNHA - INDAIÁ NO PARQUE ESTADUAL DA SERRA DO MAR - SP
}

Débora Ayumi Ishida

Orientadora: Prof ${ }^{a}$. Dr ${ }^{a}$. Maria Cristina Motta de Toledo
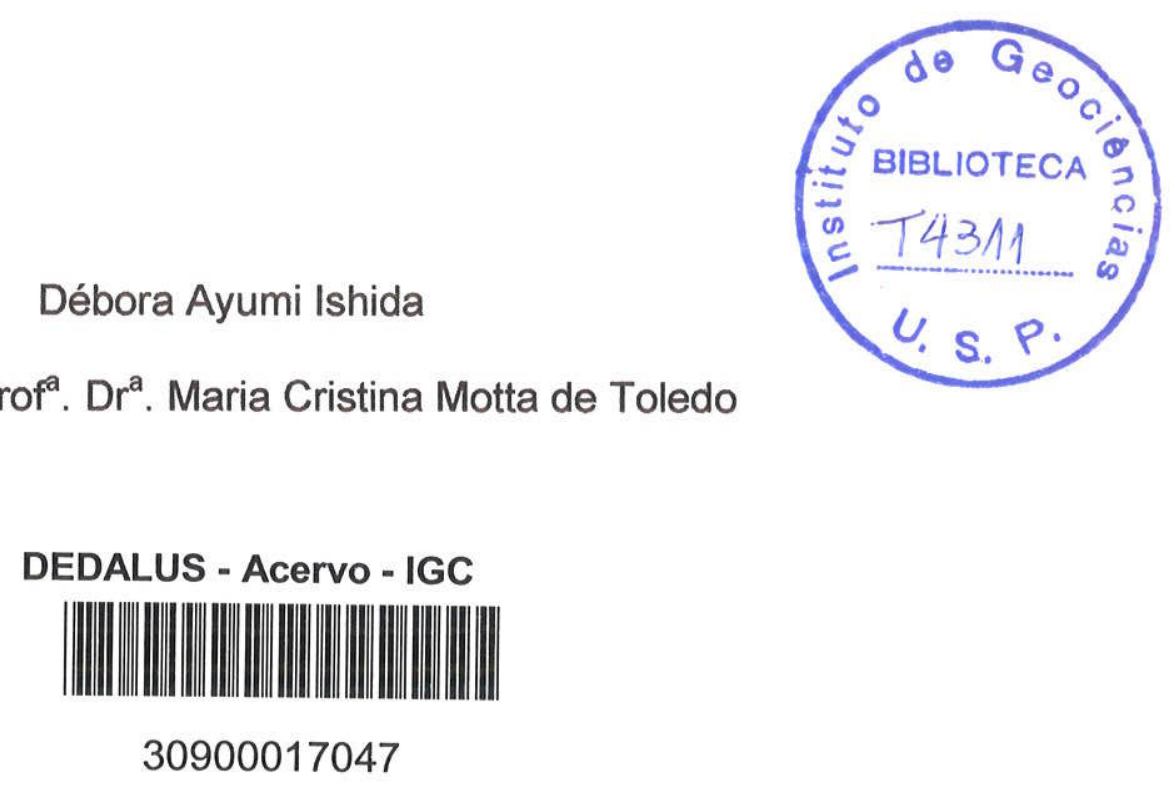

DISSERTAÇÃO DE MESTRADO

Programa de Pós-Graduação em Geoquímica e Geotectônica 


\section{ERRATA - Débora Ayumi Ishida - Dissertação de Mestrado - 2005}

Resumo - retirar título

Abstract - retirar título

Pág. 25 - linha 1 - colocar (iv) antes de textura franco -arenosa e (v) antes de cerosidade.

Pág. 47 - legenda da figura 12 - substituir Bn por Bni.

Pág. 48 - segundo parágrafo - substituir figura 12 por 13 e "do CT" por "da MO".

Pág. 64 - quarta linha - substituir $\left(I_{2}\right)$ por $\left(I_{1}\right)$.

Pág. 65 - primeira linha - substituir tabela 6 por tabela 7. Na legenda da tabela 8 substituir (8) por (3).

Pág. 66 - penúltima linha substituir muito por muitos.

Pág. 68 - substituir Bn por Bni nos três últimos parágrafos.

Pág. 69 - substituir Bn por Bni na primeira linha e trans'ição por transição.

Pág. 70 - substituir Bn por Bni nos três parágrafos.

Pág. 71 - substituir na figura 16 (c) por (a) e (d) por (b). Ainda na mesma página, substituir Bn por Bni.l

Pág. 73 - colocar na figura 17 a) e b), substituir e) por c) e retirar b).

Página 78 - na penúltima e ultima linhas substituir Bn por Bni.

Pág. 80 - na terceira linha substituir Bn por Bni. 
Aos meus pais, Sadako e Hiroshi, e a minha irmã Adriana.

Dedico. 


\section{AGRADECIMENTOS}

A Prof ${ }^{a}$. Maria Cristina Motta de Toledo pela confiança, apoio, estímulo e orientação.

A Profa. Célia Regina Montes (ESALQ/USP) pelo apoio, sugestões, críticas, co-orientação e amizade.

Ao Prof. Miguel Cooper (ESALQ/USP) pelo apoio nas análises micromorfológicas.

A Coordenação do Programa do Pós-Graduação em Geoquímica e Geotectônica do Instituto de Geociências da USP.

Aos funcionários do IGc/USP Verônica, Cláudio, Ana Paula e Magali.

Aos funcionários da ESALQ/USP Flávia, Bete, Lico, Luciano, Clotilde, Paulo, Ronaldo e Sergio.

Aos amigos Maria Ligia, Flávia, Pereira, Lucila, Herdjania, Eduardo, Luiz, Rosangela, Ana, Alex e Rubens.

Aos colegas do Nupegel/USP Vânia, Célia, Adriel, Alex, Camila (IGc), Aline (IGc) e Uwe.

Ao Conselho Nacional de Desenvolvimento Científico e Tecnológico (CNPq) pelo apoio financeiro.

A todos que contribuíram para a realização deste trabalho. 


\section{SUMÁRIO}

LISTA DE FIGURAS

Página

LISTA DE TABELAS

RESUMO

viii

SUMMARY

1 INTRODUÇÃO

$x$

2 REVISÄO DA LITERATURA

2.1 Aspectos gerais da região do Núcleo Cunha-Indaiá 4

2.1.1 Localização

2.1.2 Uso e ocupação do solo

2.1.3 As microbacias no Núcleo Cunha-Indaiá

2.1.4 Estudos desenvolvidos no Núcleo Cunha-Indaiá

2.1.5 Geologia

2.1.6 Geomorfologia 11

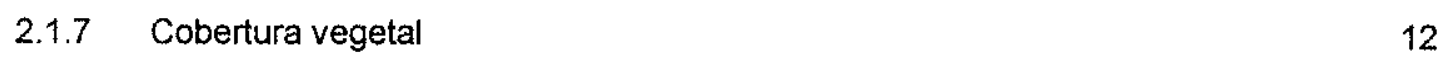

2.1.8 Clima e hidrologia $\quad 14$

2.1 .9 Solos 18

2.2 Análise estrutural da cobertura pedológica 19

2.2.1 Cartografia e análise estrutural $\quad 22$

2.3 Micromorfologia no estudo dos horizontes B latossólicos 24

2.4 Análise de imagem 29

3 CARACTERIZAÇÄO E ORGANIZAÇÃO DE UMA TOSSEQÜENCIA DE SOLOS NO PARQUE ESTADUAL DA SERRA DO MAR - SP 30

RESUMO $\quad 30$

ABSTRACT 32

3.1 INTRODUÇÃO

3.2 Material e métodos 34

3.2.1 Localização e caracterização da área de estudo 34

3.2.2 Descrição morfológica da cobertura pedológica 36 
3.2.3 Análises mineralógica, química $\theta$ física 36

$\begin{array}{lll}3.3 & \text { Resultados } \theta \text { discussão } & 39\end{array}$

3.3.1 Análise estrutural bidimensional 39

3.3.2 Descrição morfológica 39

$\begin{array}{ll}\text { 3.3.3 Caracteristicas mineralógicas e físicas } & 47\end{array}$

3.3.4 Características químicas 49

3.4 Conclusão 58

4 ESTUDOS MICROMORFOLÓGICOS DE SEQÜENCIA DE SOLOS EM

RESUMO 59

ABSTRACT 60

4.1 INTRUDUÇÃO

4.2 Material e métodos 62

4.2.1 Impregnação das amostras $\quad 62$

4.2.2 Confecção e descrição das lâminas delgadas 63

4.2.3 Microscopia eletrónica de varredura (MEV) e análise de imagem 63

4.3 Resultados e discussão $\quad 65$

4.3.1 Descrição micromorfológica dos perfis de solo 65

$\begin{array}{lll}\text { 4.3.2 Síntese das descriçōes } & 77\end{array}$

4.3.3 Análise de imagens 78

4.3.4 Conclusão 83

5 CONSIDERAÇÖES FINAIS

6 REFERÊNCIAS BIBLIOGRÁFICAS 85 


\section{LISTA DE FIGURAS}

1 Localizaçăo do Núcleo Cunha-Indaiá (Furian \& Pfeifer, 1986)

Página

2 Localizaçăo das microbacias experimentais do Núcleo Cunha-Indaiá (ANIDO, 2002)

3 Planalto de Paraitinga, relevo do tipo mamelonar 11

4 Bosque de Araucária angustifólia 13

5 Relaçăo percentual entre o volume do escoamento direto e a precipitaçăo pluvial da microbacia "B" e da microbacia "D" no periodo seco (Arcova \& Cicco, 1997)

6 Relação percentual entre o volume do escoamento direto $\theta$ a precipitação pluvial da microbacia "B" e da microbacia " $\mathrm{D}$ " no periodo chuvoso (Arcova \& Cicco, 1997)

7 Relaçăo entre a precipitação pluvial média mensal $\theta$ o escoamento total mensal (Cicco et al., 1995)

8 Flutuaçøes da turbidez (T), medida em unidades FTU (formazin turbidity unit) e da cor aparente (CA), medida em unidades de Pt-Co, da água do deflúvio da microbacia " $A$ ", no periodo de setembro de 2000 a abril de 2002 (Anido, 2002) 18

9 Localização da vertente estuda, modificado de Arcova (1996)

10 Fotomicrografias mostrando estrutura microagregada com tendência à formação de blocos subangulares.

11 Distribuição dos principais horizontes ao longo da toposseqüencia

12 Imagens obtidas por MEV mostram a evidente diminuição na porosidade (cor preta) entre os horizontes BA e Bw1 (Figuras a e b) e as estruturas prismáticas, indicadas por seta, dos horizontes $\mathrm{Bn} 2$ e $\mathrm{Bn} 3$ (Figuras $\mathrm{c}$ e d) do perfil 4

13 Difratograma da fração argila natural deferrificada do perfil 13 mostrando a diminuição da VHE

14 Fotomicrograflas: (a) poro preenchido por gibbsita micro cristalina (b) muscovita em alteraçăo e fragmento de quartzo trincado

15 Fotomicrografias:

(a) microagregados $\theta$ (b) blocos subangulares

16 Fotomicrografias: (a) evidências de expansão e contração do material e (b) domínios gibbsíticos 
17 Fotomicrografias: (a) e (b) mudança de cor e aumento da porosidade entre o horizonte Bw2 e a transiçăo Bn1/Bw2 (c) evidências de expansăo e contraçăo do material ao redor do esqueleto, (d) microestrutura complexa $\theta$ (e) pedotúbulos

18 Fotomicrografias: (a) esqueleto constituido por microclinio (MC), biotita (B) e quartzo $(Q)$, (b) biotita $(B)$ em alteração e (c) microcilnio $(M c)$ ao lado de fragmentos de quartzo $(Q)$ e de biotita

19 Fotomicrografias: (a) esqueleto constituido por microclinio (Mc), biotita e quartzo (Q), (b) plasma mais abundante $e$ (c) nódulo de ferro com fragmentos de mica

20 Fotomicrografias: (a) granada alterada (G) ao lado de feldspato (F) ferruginizado, (b) e (c) pseudomorfos de biotita (B)

21 Fotomicrografias: (a) mica em alteração com ferruginizaçăo $\theta$ (b) principio da alteraçăo de microclínio em sericita ao lado de biotita sã

22 Média da porosidade total e desvio padrão dos horizontes do perfil 4 (Latossolo Amarelo Distrófico argissólico). A partir do teste de Tukey, as médias dos horizontes, que possuem a mesma letra, năo diferem entre si a $5 \%$

23 Distribuição da porosidade total, dos horizontes do perfil 4 (Latossolo Amarelo Distrófico argissólico), em função da forma $\theta$ do tamanho dos poróides. Arre. = arredondados, Along. $=$ alongados e Comp. $=$ complexos 


\section{LISTA DE TABELAS}

1 Área $\theta$ altitude das microbacias hidrográficas

2 Caracteristicas morfológicas dos perfis estudados

3 Caracteristicas mineralógicas

4 Caracteristicas fisicas

5 Resultado das análises químicas dos perfis 5 (Latossolo Amarelo Distrófico típico), 6 (Latossolo Amarelo Distrófico câmbico) e 13 (Latossolo Amarelo Distrófico argissólico)

6 Resultado das análises químicas dos perfis 4 (Latossolo Amarelo Distrófico argissólico) e 2 (Cambissolo Háplico Alumínico típico)

7 Definição das classes de forma dos poróides

8 Definiçăo das classes de tamanho versus forma dos poróides 
ESTUDO MACRO E MICROMORFOLÓGICO DE HORIZONTES PRISMÁTICOS EM LATOSSOLOS DE MICROBACIA HIDROGRÁFICA EXPERIMENTAL NO NÚCLEO CUNHA - INDAIÁ NO PARQUE ESTADUAL DA SERRA DO MAR - SP

Autora: DÉBORA AYUMI ISHIDA Orientadora: Prof . MARIA CRISTINA MOTTA DE TOLEDO

\section{RESUMO}

A literatura relacionada à classe dos Latossolos é bastante extensa, sobretudo na região intertropical. No entanto, Latossolos que apresentam horizontes prismáticos em profundidade foram pouco estudados. No Núcleo Cunha-Indaiá do Parque Estadual da Serra do Mar encontram-se três microbacias hidrográficas, denominadas " $A$ ", "B" e "D", onde são realizados diversos estudos. Somente os solos da microbacia hidrográfica "B", apresenta estes horizontes prismáticos. Com isso, este trabalho teve como objetivo principal estudar tais horizontes. Para isso, foi realizada: (i) análise estrutural da cobertura pedológica, (ii) caracterização e classificação dos solos utilizando atributos químicos, físicos e mineralógicos e (iii) caracterização micromorfológica visando compreender a formação deste solo desde o material de origem e alteração até o solo e determinar a quantidade, forma e tamanho dos poros. 


\title{
MACRO AND MICROMORPHOLOGICAL STUDIES OF PRISMATIC HORIZONS IN OXISOILS OF EXPERIMENTAL SMALL WATERSHEDS IN THE "NÚCLEO CUNHA-INDAIA" OF THE "PARQUE ESTADUAL DA SERRA DO MAR" - SP
}

Author: DÉBORA AYUMI ISHIDA Adviser: Prof. MARIA CRISTINA MOTTA DE TOLEDO

\begin{abstract}
The literature related to the class of Oxisol is quite extensive, mainly in the area intertropical. However the Oxisois that present prismatic horizons in depth have been little studied. In the "Núcleo Cunha-Indaiá" of the "Parque Estadual da Serra do Mar" they are three small watersheds, denominated "A", "B" and "D", where several studies have carried out. Only the soils of the small watershed " $B$ ", presents these prismatic horizons. This work had as main objective to study such horizons, by the following aspects: (i) structural analysis of the pedologic covering, (ii) characterization and classification of the soils by chemical, physical and mineralogical attributes and (iii) micromorphological characterization to understand the pedogenesis process from the origin material and its alteration to the soil, besides to determine the amounts, forms and size of the pores.
\end{abstract}




\section{INTRODUÇÃO}

Originalmente a Mata Atlântica estendia-se paralelamente à costa brasileira. Na região sudeste, avançava pelo interior do país, englobando o conjunto de terras altas constituído pelas serras do Mar, da Mantiqueira e do Espinhaço.

A evolução da degradação dessa floresta tropical úmida acompanha o desenvolvimento histórico-econômico do país. O início da colonização marcou também o início da devastação da Mata Atlântica, que presenciou os ciclos da cana-de-açúcar, do ouro, do café e da industrialização/urbanização. Esta formação florestal foi, em sua maior porção, substituída e, atualmente, é ocupada pela agricultura e por grandes centros urbanos, como Rio de Janeiro e São Paulo.

Apesar dessa longa história de devastação, os remanescentes de Mata Atlântica compõem parte importante do patrimônio ambiental brasileiro. No estado de São Paulo, apenas $8 \%$ dessa floresta encontra-se preservada, em grande parte devido à criação do Parque Estadual da Serra do Mar em 1977. Este parque ocupa uma área de 309.938 hectares, desde a fronteira com o Estado do Rio de Janeiro até Itariri, no sul do Estado, passando por toda a faixa litorânea. O Parque Estadual da Serra do Mar abrange 28 municípios e representa a maior porção contínua preservada de Mata Atlântica do país.

No ano de 1998, a Serra do Mar foi integralmente tombada pela UNESCO, inclusive os remanescentes de Mata Atlântica no estado de São Paulo. Alguns desses remanescentes, localizados nas proximidades dos centros urbanos, como o Parque Estadual das Fontes do Ipiranga, ainda que 
legalmente preservados, sofrem a influência da ação antrópica por estarem sujeitas à deposição de poluentes transportados pelos ventos e chuvas. Outros, como o Núcleo Cunha do Parque Estadual da Serra do Mar, estão distantes dos centros urbanos e industriais, sendo considerados livres de poluição.

A proteção e a manutenção desses remanescentes de áreas naturais de Mata Atlântica e de sua biodiversidade vêm, desde a criação do Parque Estadual da Serra do Mar, despertando o interesse de pesquisadores preocupados em compreender e preservar esse sistema, bem como em avaliar os efeitos da poluição.

Em 1974 foi criada a Reserva Florestal de Cunha que recebeu o nome de Núcleo Cunha do Parque Estadual da Serra do Mar em 1977, ano da criação do Parque. O Instituto Florestal, órgão da Secretaria do Meio Ambiente do Estado de São Paulo, administra o parque (Arcova, 1996).

Essas áreas montanhosas florestadas, sob influencia de massas de ar oceânicas, são importantes áreas fornecedoras de água doce para a região do Vale do Paraiba e Litoral Norte paulista. Além disso, o recebimento e distribuição da água das chuvas em bacias hidrográficas estão fortemente relacionados com a vegetação, que influencia 0 processo de evapotranspiração e a alimentação dos aquuiferos e das águas superficiais (Arcova \& Cicco, 1997).

O conhecimento das interações que ocorrem nas interfaces águasolo-vegetação-atmosfera é imprescindível para o estabelecimento de políticas públicas e estratégias visando o uso racional dos recursos naturais. Por isso, são de grande importância os estudos relacionados aos processos hidrológicos, geoquímicos e morfopedológicos que ocorrem nessas microbacias.

O objetivo geral deste trabalho foi estudar a ocorrencia de horizontes prismáticos em Latossolos desenvolvidos sob floresta tropical úmida. Assim, o trabalho foi subdividido em duas partes: (i) caracterização morfológica, 
mineralógica, química e física de uma seqüência de solos e (ii) estudo detalhado dos horizontes prismáticos a partir da caracterização micromorfológica da seqüencia de solo. 


\section{REVISÃO DA LITERATURA}

\subsection{Aspectos gerais da região do Núcleo Cunha-Indaiá}

\subsubsection{Localização}

O Núcleo Cunha-Indaiá do Parque Estadual da Serra do Mar possui área total de 2.854 ha e localiza-se a nordeste do Estado de São Paulo, entre as coordenadas geográficas $23^{\circ} 13^{\prime} 28^{\prime \prime}$ e $23^{\circ} 16^{\prime} 10^{\prime \prime} \mathrm{S}$ e $45^{\circ} 02^{\prime} 53^{\prime \prime}$ e $45^{\circ} 05^{\prime} 15^{\prime \prime}$ W (Figura 1). Encontra-se a cerca de $15 \mathrm{~km}$ da costa e a $2.000 \mathrm{~m}$ de altitude, e está inserido no alto e médio vale do rio Paraibuna, no planalto do Paraitinga (Furian \& Pfeifer, 1986).

\subsubsection{Uso e ocupação do solo}

O conhecimento a respeito do uso do solo na região do Núcleo Cunha-Indaiá está vinculado ao uso do solo no Vale do Paraíba, mais precisamente no setor Alto Vale do Paraiba, no qual o Núcleo está inserido.

A região do Vale do Paraíba que está situada entre as macrounidades Serra da Mantiqueira e a Serra do Mar, acompanhou a evolução histórico-econômica do Brasil, passando pelos Ciclos do Ouro e do Café, chegando ao surto de industrialização/urbanização ocorridos em meados do século passado.

Revisando historicamente o uso do solo da região, podemos dividi-lo em três importantes períodos. O primeiro período (séculos XVII - XVIII) corresponde à época das bandeiras, expediçōes direcionadas ao interior, financiadas pelo capital particular e com objetivos comerciais. Esse periodo também é marcado pelo declínio da comercialização da cana-de-açúcar do 
nordeste e pelo início da exploração de ouro no interior da região sudeste. As principais conseqüências desse período foram o aumento populacional, a rápida ocupação do interior e o desenvolvimento do eixo econômico do sudeste (Prandini et al., 1982).

Neste período, o abastecimento da região das Minas Gerais era realizado pelo setor do Médio do Vale do Paraíba. As trilhas indígenas que avançavam sobre as serra do Mar e da Mantiqueira, originaram os caminhos utilizados pelos tropeiros para alcançar o litoral, o Rio de Janeiro e Minas Gerais (Prandini et al., 1982).

Data dessa época o surgimento das primeiras vilas, locais de pousada e reabastecimento das tropas. Mais tarde, estes vilarejos se transformariam em cidades como Lorena, Caçapava, Taubaté, Cunha e outras. O ouro das Minas Gerais passava pelo Vilarejo de Falcão, que mais tarde se tornaria Cunha, em direção a Parati, de onde partia para o Rio de Janeiro via mar (Prandini et al., 1982).

Além dos caminhos utilizados pelas tropas, o Alto Vale era marcado pelo cultivo em pequenas lavouras e pela criação de suínos, cujo excedente abastecia o setor do Médio Vale (Prandini et al., 1982).

O segundo periodo (século $\mathrm{XIX}$ ) corresponde ao chamado surto cafeeiro. Até então, o café era produzido apenas para consumo interno. $O$ declínio da produção haitiana marcou o início da elevação do café à posição de produto base da economia brasileira. Inicialmente o café era cultivado apenas na Baixada Fluminense.

O excedente de escravos, as estradas abertas para o transporte de mercadorias e os meios de transporte (tropas de mulas) formam um conjunto de fatores que favoreceram a rápida expansão da cafeicultura no Vale do Paraíba.

Nesse período, a monocultura do café propiciou incremento da população e enriquecimento da região e também, provocou a degradação da vegetação primária e do solo com o uso intensivo e desordenado. 


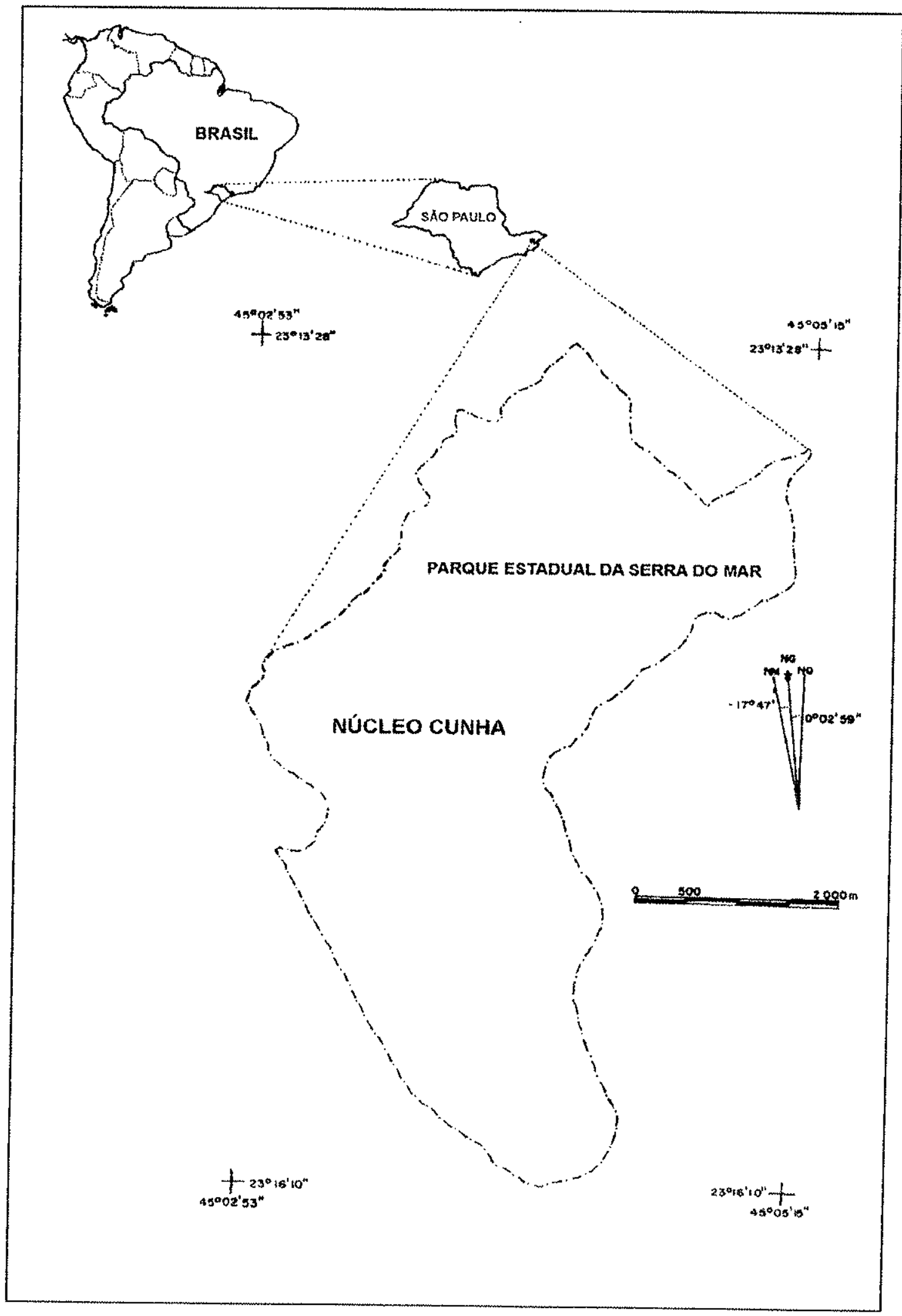
1986).

Figura 1 - Localização do Núcleo Cunha-Indaiá (Furian \& Pfeifer, Isto intensificou os processos de erosão de encostas e assoreamento dos cursos de água, o que vem dificultando a produção de água. 
No setor do Alto Vale do Paraíba, o café não passou de uma efêmera atividade agrícola, tanto no tempo como no espaço (Prandini et al., 1982). As formas do relevo e as condições climáticas limitaram a expansão da cultura do café neste setor. O relevo, como será mostrado posteriormente, tem condicionado os processos de regeneração da vegetação.

O terceiro período corresponde ao processo de industrialização e urbanização. No início do século XX começa o processo de expansão industrial no país, gerado a partir de transformações sócio-econômicas, tais como o fim da escravidão e a chegada de imigrantes europeus. O Ciclo do Café possibilitou o desenvolvimento industrial, através da ampliação do mercado consumidor, da disponibilidade dos recursos anteriormente empregados na compra de escravos e da infra-estrutura utilizada para o transporte do café.

O Alto e Médio Vale do Paraíba contribuíram para o processo de industrialização fornecendo carvão vegetal às indústrias e siderúrgicas dos estados de São Paulo e Rio de Janeiro. Neste surto de industrialização no Alto Vale as matas foram retiradas para fornecer carvão vegetal e madeira para construção. Por isso, esta área teve como herança desse período desmatamento e atividade pecuária (Prandini et al., 1982).

A partir da década de 1960, no setor do Médio Vale desenvolveu-se o segundo eixo industrial da região sudeste, beneficiando-se de sua posição entre São Paulo e Rio de Janeiro, grandes mercados consumidores.

Depois de décadas de constante devastação dos recursos naturais, no início da década de 1970 , os políticos e a sociedade começam a despertar para a necessidade de preservação. A partir desse movimento foram criados parques e reservas estaduais. Apesar desses esforços, somente $8 \%$ da Mata Atlântica, no estado de São Paulo, está preservada, e mesmo assim, ainda sofre forte pressão antrópica. 


\subsubsection{As microbacias no Núcleo Cunha-Indaiá}

Há no Núcleo Cunha-Indaiá três microbacias hidrográficas que vêm sendo objeto de estudo de pesquisadores do Laboratório de Hidrologia Florestal Walter Emmerich.

Os projetos de pesquisa ali desenvolvidos visam o monitoramento e entendimento do sistema natural, a fim fornecer informações aos programas de uso sustentável e de recuperação de áreas similares já degradadas. Estas informações a respeito do funcionamento de um ecossistema preservado säo indicadores qualitativos e quantitativos utilizados no diagnóstico, no manejo e na recuperação de áreas degradadas.

As microbacias hidrográficas denominadas " $A$ ", " $B$ " e " $D$ ", inseridas neste importante ecossistema natural da Mata Atlântica (Figura 2), apresentam as seguintes caracteristicas (Tabela 1):

Tabela 1 - Área e altitude das microbacias hidrográficas.

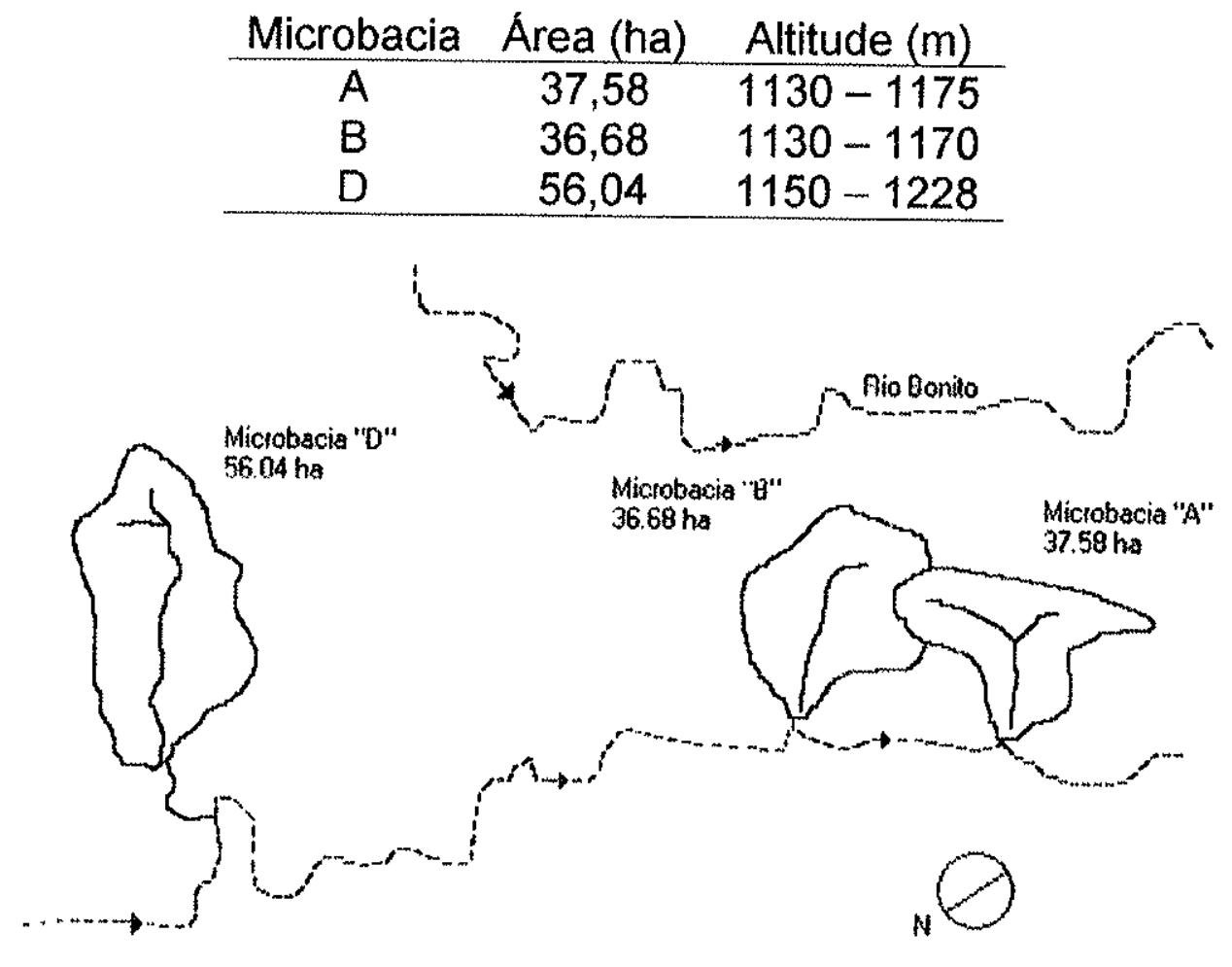

Figura 2 - Localização das microbacias experimentais do Núcleo Cunha-Indaiá (ANIDO, 2002). 


\subsubsection{Estudos desenvolvidos no Núcleo Cunha-Indaiá}

Estudos relacionados ao funcionamento, uso sustentável e preservação dos recursos naturais vêm sendo desenvolvidos na escala da microbacia. Tal escala de observação facilita a coleta de dados detalhados e por longos períodos, além de tornar possível o estabelecimento de modelos conceituais a respeito do funcionamento dessas unidades da paisagem. Por isso, programas de estudos integrados em microbacias vêm sendo implementados nas áreas relacionadas à pesquisa e à educação ambiental (Bicudo et al., 2002).

Com isso, em 1979, com a colaboração do Governo Japonẻs, por meio do convênio firmado entre o Instituto Florestal de São Paulo e a Japan Internacional Cooperation Agency, desenvolveu-se no Núcleo Cunha-Indaiá do Parque Estadual da Serra do Mar, um Projeto de Manejo de Bacias Experimentais. Este projeto teve duração de sete anos e objetivo de fornecer informações a respeito do Vale do Paraíba paulista para assegurar o suprimento de água e conter os processos erosivos, através de reposição de cobertura vegetal adequada. Este projeto assegurou a instalação do Laboratório de Hidrologia Florestal Eng $^{\circ}$. Agr ${ }^{\circ}$. Walter Emmerich, a contenção de encostas e a reposição da cobertura vegetal, e gerou trabalhos importantes para a conservação da área (Arcova et al., 1998).

Em 1999, teve início o projeto "Ciclos biogeoquímicos e transferências de espécies químicas nas interfaces de ecossistemas terrestres de Mata Atlântica: estudo de duas áreas contrastantes" com suporte financeiro da Fundação de Amparo à Pesquisa do Estado de São Paulo (FAPESP).

Este projeto estendeu-se até 2002 e teve como objetivo caracterizar as transferências nas interfaces atmosfera-solo-água, de 
espécies químicas (nitrato, sulfato, amônio, cátions básicos e metais pesados) presentes nas soluções aquosas e quantificar essas espécies na água de chuva, na transprecipitação, na solução do solo e no curso d'água, para relacioná-los com o da vegetação local e, assim, com efeitos de poluição atmosférica (Bicudo et al., 2002).

Para atingir o objetivo foi implantado um programa de monitoramento integrado em duas microbacias hidrográficas localizadas em duas áreas remanescentes de Mata Atlântica. Uma delas, tomada como referência, situada na porção leste do Parque Estadual da Serra do Mar, o Núcleo de Cunha-Indaiá considerado livre de poluição tanto atmosférica quanto hidrológica, e a outra, localizada na porção central Parque Estadual das Fontes do Ipiranga (PEFI). O PEFI encontra-se na região metropolitana de São Paulo, em área de preservação de manancial e está sob influência da poluição pela sua proximidade com o sitio urbano. Em ambas, o monitoramento ambiental foi efetuado através do estudo físico-químico, da precipitação, da transprecipitação, da solução do solo, solo e curso d'água (Bicudo et al., 2002).

\subsubsection{Geologia}

O substrato geológico da região pertence ao Complexo Cristalino, do periodo Pré-Cambriano e possui litologia constituida por granitos, gnaisses, xistos (micaxistos e quartzoxistos) e migmatitos (Brasil, 1960).

No Núcleo Cunha-Indaiá as rochas mais comuns são gnaisses, migmatitos e granitos, que, alteradas, resultam em solos quimicamente pobres, ou seja, com perda de bases e permanência de óxidos de ferro e alumínio, como é o normal neste domínio climático, com textura grossa, fraca estruturação e boa drenagem (Furian \& Pfeifer, 1986). 


\subsubsection{Geomorfologia}

O Núcleo Cunha-Indaiá, do Parque Estadual da Serra do Mar", está inserido na província geomorfológica do Planalto Atlântico e ocupa a zona geomorfológica do Planalto do Paraitinga. Apresenta relevo do tipo "mar de morros e/ou de meias laranjas", típico da Serra do Mar. Contudo, no Núcleo de Cunha-Indaiá, o relevo apresenta-se num estágio mais avançado da evolução geomorfológica, com formas mamelonares comuns do Planalto de Piraitinga (Figura 3).

O relevo do Núcleo Cunha-Indaiá apresenta forte influência estruturallitológica e de erosão diferencial (Furian \& Pfeifer, 1986), por isso a manutenção da cobertura vegetal é de extrema importância para a estabilidade das vertentes.

O relevo da microbacia "B" caracteriza-se por topos arredondados, com altitudes variando entre $1.130 \mathrm{~m}$ e $1.170 \mathrm{~m}$, e por vertentes íngremes, as maiores declividades entre $58 \%$ a $97 \%$. A partir da meia vertente, em direção a jusante, os terrenos apresentam forma côncava, entrecortados por vertentes abruptas de altas declividades, observando-se expressivas rupturas tanto nas formas como nas declividades das vertentes (Arcova \& Cicco, 1997).

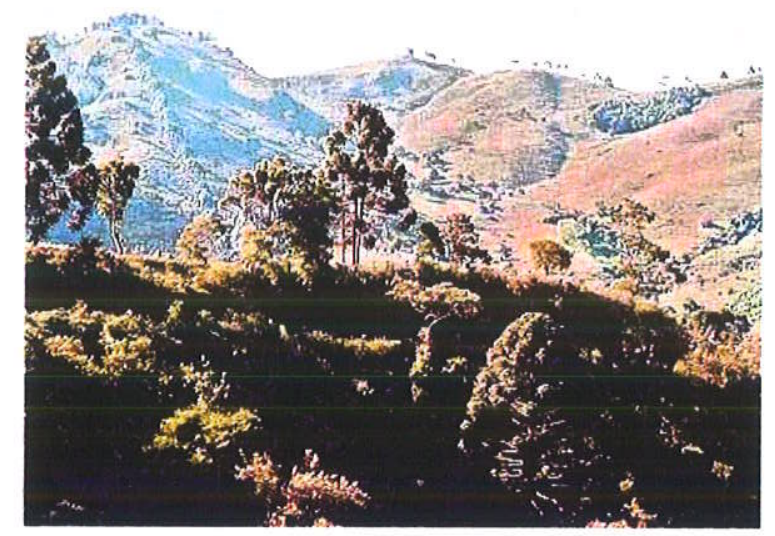

Figura 3 - Planalto de Paraitinga, relevo do tipo mamelonar.

A microbacia "D" apresenta relevo de topos abaulados, caracterizado por trechos com faces íngremes e exposição de paredes rochosas e trechos 
com faces pouco íngremes a arredondadas. Os terrenos mais íngremes apresentam-se espacialmente dispersos e predominantemente localizados junto aos divisores de água, e possuem declividades entre $58 \%$ a $97 \%$. As formas das vertentes são retilíneo-côncavas. Formas convexas são observadas em alguns trechos próximos aos topos abaulados e nos segmentos das baixas vertentes, onde há contatos abruptos com o fundo de vale, definidos preferencialmente pela existência de rochas (Arcova \& Cicco, 1997). Na vertente estudada da microbacia "B", para o presente trabalho, foram observadas estas formas de relevo convexas. Nos médios e baixos compartimentos, os depósitos de vertentes são expressivos e suavizam os contatos das vertentes com o fundo de vale, caracterizando as vertentes côncavas (Arcova \& Cicco, 1997).

$\mathrm{Na}$ alta microbacia " $\mathrm{D}$ " diversos escorregamentos foram registrados, em setores de vertentes retilineas íngremes, próximos aos topos mais destacados. Nestas vertentes, a ocorrência de fatores predisponentes e efetivos à instabilidade, tais como a ação antrópica pretérita, as altas declividades e os episódios pluviométricos concentrados e de alta intensidade, imprimem um aumento do poder erosivo do escoamento direto concentrado, resultando em canais pluviais ravinados e cicatrizes de escorregamentos reativadas. Estas áreas são responsáveis pelo maior fornecimento de sedimentos aos canais de drenagem (Domingues et al., 2001).

\subsubsection{Cobertura vegetal}

A vegetação original da região foi classificada como Floresta Latifoliada Perenifólia - Mata Atlântica que se desenvolve em altitudes superiores a $1.000 \mathrm{~m}$ (Leitão Filho, 1982).

A vegetação primitiva é encontrada somente nas áreas de difícil acesso, tais como encostas de maiores declividades e nos topos dos morros (Prandini et al., 1982). Nas demais áreas a floresta deu lugar a pastagens e 
plantações ou forneceu carvão e madeira. Assim, nessas áreas desmatadas, desenvolve-se, há mais de 20 anos, uma floresta secundária.

Aguiar (2001) realizou, em um trecho de vegetação secundária, um levantamento florístico das espécies arbóreas e arbustivas, com destaque para Myrtaceae, Lauraceae, Solanaceae, Asteraceae e Melastomataceae.

Em mapeamento da cobertura vegetal realizado na microbacia " $D$ ", foram encontrados estágios naturais de desenvolvimento de vegetação secundária e pequeno bosque de Araucária angustifólia (Figura 4) (Domingues et al. 2001). Estes estágios estão diretamente relacionados aos aspectos da dinâmica do relevo.

A regeneração da vegetação, nas áreas de altas vertentes e topos abaulados, vem ocorrendo de forma mais lenta. Isto se deve a fatores limitantes como as altas declividades, as vertentes retilíneas, a maior densidade de drenagem de canais temporários, a existência de ravinas e sulcos de erosão e a constante perda da camada superficial do solo. Esta vegetação foi caracterizada como vegetação secundária em estágio inicial de regeneração. Devido à maior umidade e ao espessamento da serrapilheira, ocorre, nas planícies de deposição, a vegetação caracterizada como secundária em estágio médio de regeneração (Domingues et al., 2001).

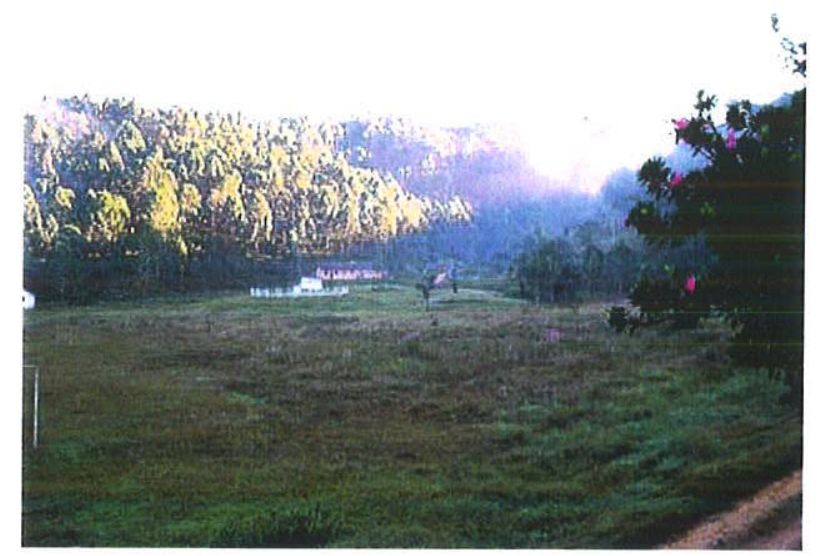

Figura 4 - Bosque de Araucária angustifólia. 
Nas vertentes localizadas do lado direito do médio curso do ribeirão do Barracão, a vegetação encontra-se em estágio avançado de regeneração. Aspectos do relevo como forte ruptura de declive, vertentes retilíneas e altas declividades, imprimem a essa área uma provável retirada seletiva de árvores e não a retirada total da vegetação, constatada no restante da microbacia " $D$ ". Isto propiciou a manutenção de um banco de sementes e condições para a instalação de estágio avançado de regeneração (Domingues et al., 2001).

Conclui-se que os diferentes estágios de regeneração da vegetação estão vinculados às diferentes formas do relevo. Em trabalho de campo realizado na microbacia " $\mathrm{B}$ ", foi observado a ocorrência de processos erosivos mais intensos nos trechos de maiores declividades da vertente, dificultando a regeneração da vegetação.

\subsubsection{Clima e Hidrologia}

Regionalmente, a orientação da Serra do Mar (SE-NE), a proximidade com o Oceano Atlântico, as altas altitudes e a influência de massas de ar são fatores importantes a serem considerados, pois colaboram com as condições climáticas locais.

O clima da região é do tipo Cwa (classificação Köppen), mesotérmico de inverno seco com temperaturas no inverno inferiores a $18^{\circ} \mathrm{C}$ e no verão superiores a $22^{\circ} \mathrm{C}$ (Furian \& Pfeifer, 1986). A temperatura média anual é de $16,5^{\circ} \mathrm{C}$ e as médias anuais, máxima e mínima, são, respectivamente, de $20,6^{\circ} \mathrm{C}$ e $6,6^{\circ} \mathrm{C}$ (inverno) e de $26,3^{\circ} \mathrm{C}$ e $16,0^{\circ} \mathrm{C}$ (verão) (Fujieda et al., 1997). No mês mais seco o total de precipitação pluvial não ultrapassa $30 \mathrm{~mm}$, sendo a média anual entre 1.100 e $1.700 \mathrm{~mm}$, com periodo chuvoso entre outubro a março (Furian \& Pfeifer, 1986).

Foi estudada a relação percentual entre o volume do escoamento direto (volume de água que causa o aumento rápido da vazão de microbacias durante e imediatamente após a ocorrencia de uma chuva e que atinge rapidamente os cursos d'água. Compreende o escoamento superficial 
e o subsuperficial e é utilizado quando é impossível separar o escoamento subsuperficial nas análises hidrológicas) e a precipitação pluvial que o gerou nas microbacias "B" e "D".

As microbacias apresentaram um comportamento muito diferenciado quanto à resposta hidrológica (Arcova \& Cicco, 1997). Na figura 5 observase que no período seco, chuvas de até $50 \mathrm{~mm}$ provocaram escoamento direto numa faixa de $10 \%$ a $35 \%$ da precipitação pluvial na microbacia " $\mathrm{B}$ ". Enquanto, na microbacia " $D$ " este percentual raramente ultrapassou $10 \%$. Este comportamento é ainda mais evidente no período chuvoso.
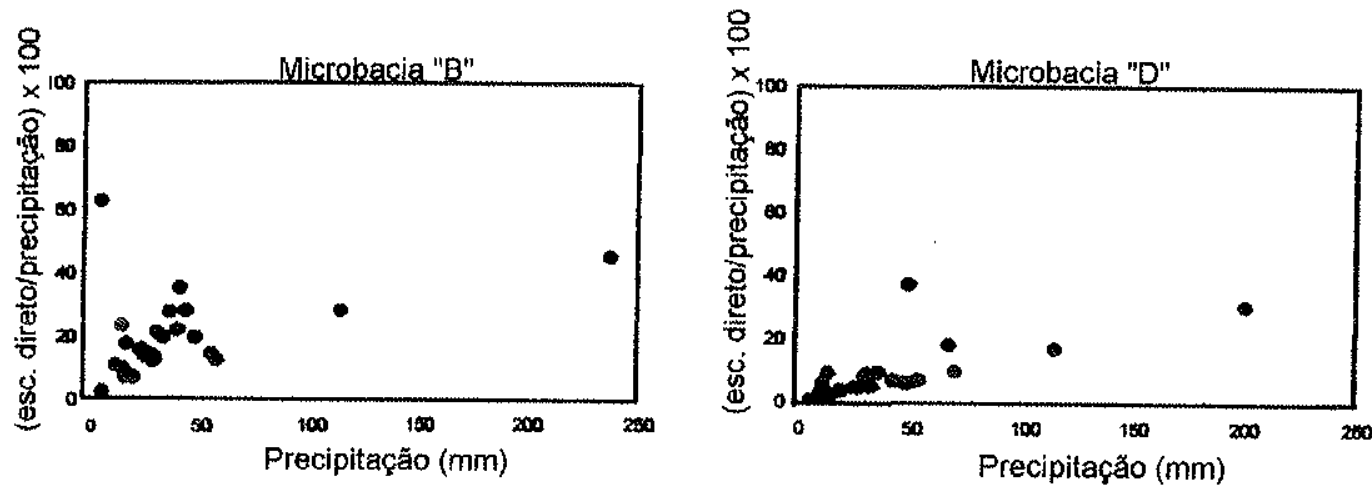

Figura 5 - Relação percentual entre o volume do escoamento direto e a precipitação pluvial da microbacia " $B$ " e da microbacia " $D$ " no período seco (Arcova \& Cicco, 1997).

$\mathrm{Na}$ figura 6 observa-se que eventos de até $50 \mathrm{~mm}$ provocaram escoamento direto até $50 \%$ da precipitação pluvial na microbacia " $\mathrm{B}$ " e de até $30 \%$ na microbacia " $\mathrm{D}$ ".

Foram estimados, a partir de oitenta e oito hidrogramas, os fatores de resposta médios, o quociente entre o escoamento direto e o escoamento total do hidrograma, e o quociente entre o escoamento direto e a precipitação que o gerou, das microbacias " $B$ " e " $D$ ". O fator da microbacia "B" $(0,23)$ foi duas vezes superior ao da microbacia " $D$ " $(0,12)$ (Arcova \& Cicco, 1997). 

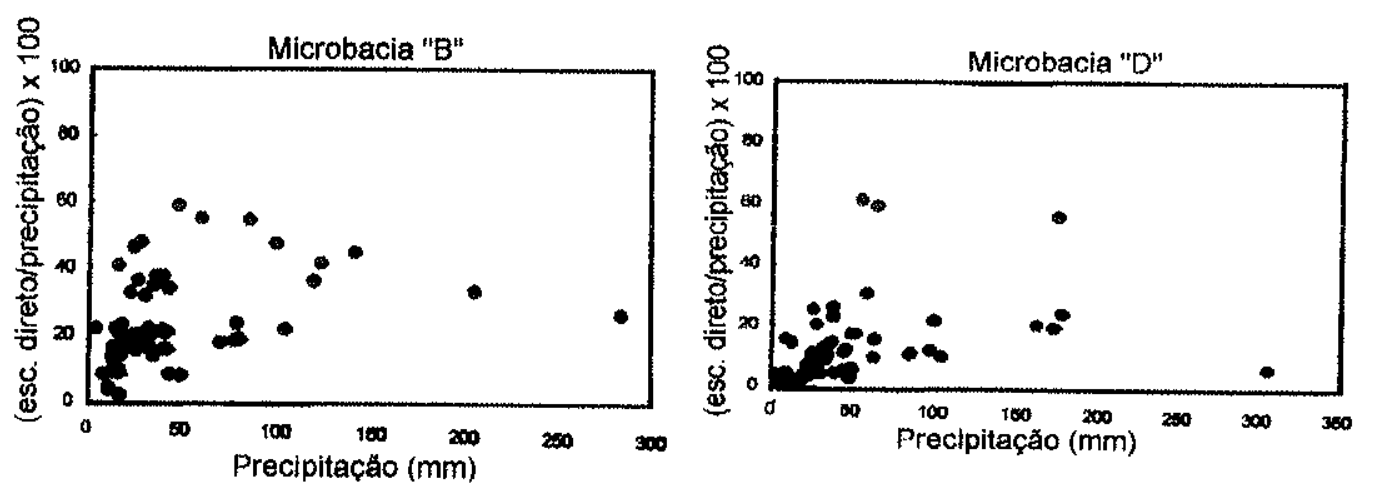

Figura 6 - Relação percentual entre o volume do escoamento direto e a precipitação pluvial da microbacia " $B$ " e da microbacia " $D$ " no período chuvoso (Arcova \& Cicco, 1997).

O comportamento diferenciado da resposta hidrológica nas microbacias deve-se às diferentes condições morfológicas dessas áreas. $O$ maior escoamento direto da microbacia "B" em relação à microbacia " $D$ " está relacionado com a maior declividade de suas vertentes e, como conseqüência, a existência de perfis de solo pouco desenvolvidos, e a afloramentos de rochas alteradas nas porções inferiores da microbacia, que favorecem os fluxos superficiais. Enquanto a microbacia " $D$ " possui ampla planície com solos hidromórficos e aluviais que tendem a armazenar mais água liberando-a de forma mais lenta (Arcova \& Cicco, 1997).

A figura 7 apresenta a relação entre a precipitação pluvial média mensal e o escoamento total na microbacia " $D$ ". Nos meses entre janeiro a março, periodo de recarga, ocorre o escoamento máximo, e o escoamento mínimo ocorre no inverno e início da primavera. Entre os meses de maio a agosto, notou-se que o escoamento total foi superior à precipitação. Isto indica que parte da precipitação pluvial do período de recarga é armazenada na forma de água no solo e de fluxo de água subterrânea, podendo abastecer o sistema no período seco (Cicco et al., 1995). 


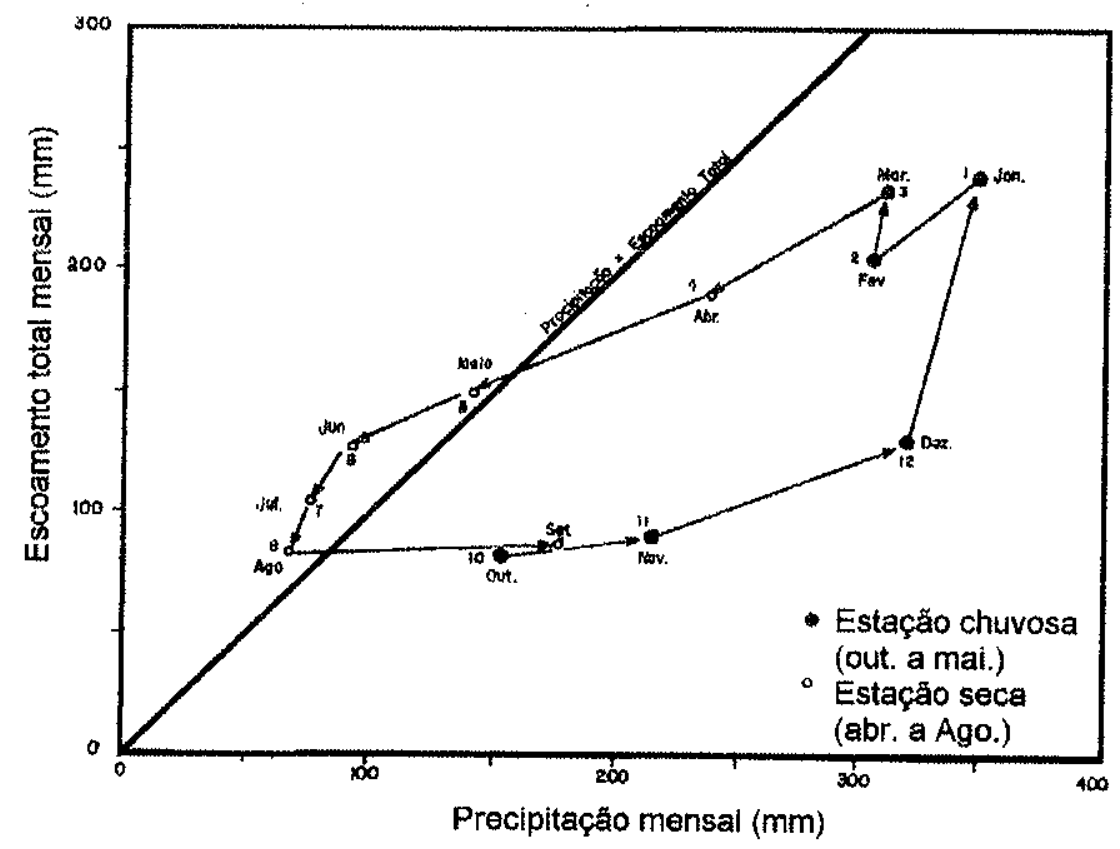

Figura 7 - Relação entre a precipitação pluvial média mensal e o escoamento total mensal (Cicco et al., 1995).

Anido (2002) estudou os parâmetros de cor e turbidez ${ }^{1}$ da água do deflúvio da microbacia "A" no período de setembro de 2000 a abril de 2002. $\mathrm{Na}$ figura 8 os picos correspondem às enchentes ocasionadas pelas precipitações. A correlação de valores de turbidez e cor aparente da água do deflúvio produz um coeficiente de correlação $r^{2}$ de 0,96 . Isto indicaria que as flutuações da cor aparente seriam, em grande parte, explicadas pela flutuação da turbidez. No entanto, em áreas florestadas como da microbacia " $A$ " esta relação é influenciada pela alta proporção de sedimentos e matéria orgânica presentes na água e que aumentam com as precipitações.

\footnotetext{
${ }^{1}$ A turbidez da água define a alteração da penetração da luz em uma amostra, causada por partículas em suspensão de origem orgânica ou inorgânica, material coloidal, plâncton $\Theta$ outros organismos microscópicos. A cor da água é definida pela presença de íons metálicos ( $\mathrm{Fe}$ e $\mathrm{Mn}$ ), de ácidos húmicos, de material coloidal, de partículas de origem orgânica ou não e por resíduos industriais (ANIDO, 2002).
} 


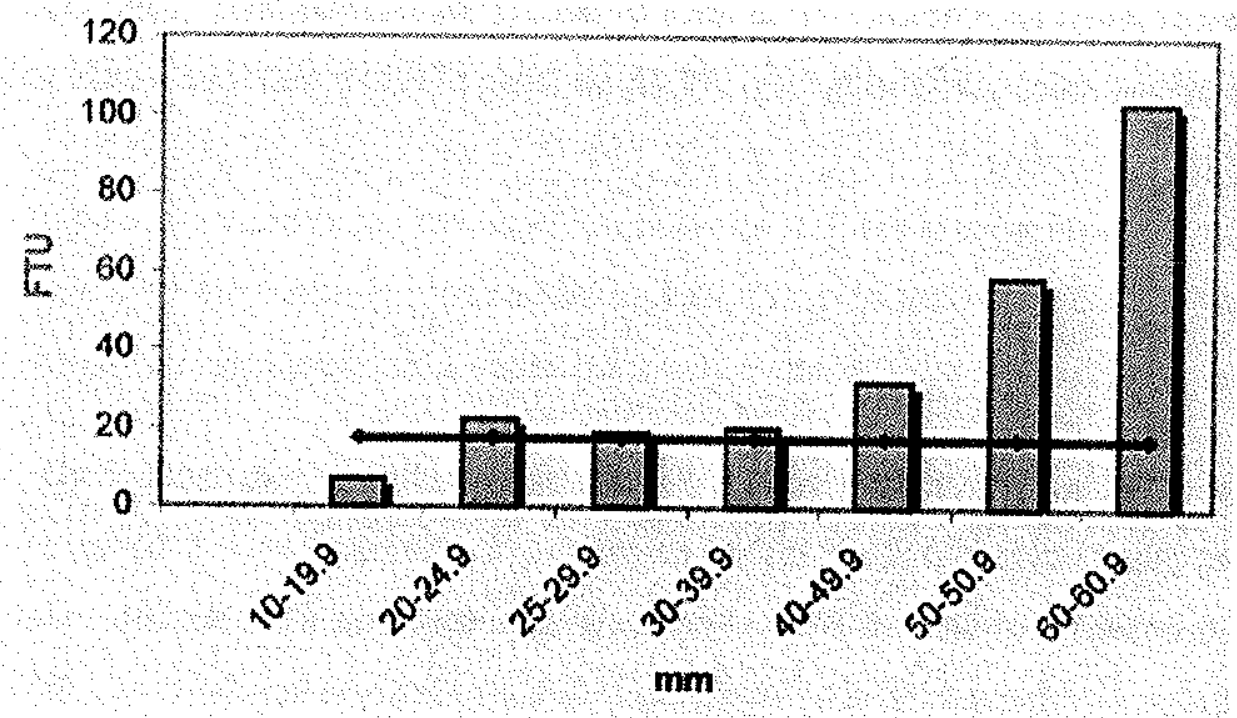

Figura 8 - Flutuações da turbidez $(T)$, medida em unidades FTU (formazin turbidity unit) e da cor aparente (CA), medida em unidades de Pt-Co ${ }^{2}$, da água do deflúvio da microbacia " $A$ ", no período de setembro de 2000 a abril de 2002 (Anido, 2002).

\subsubsection{Solos}

O levantamento de reconhecimento detalhado dos solos realizado na microbacia " $\mathrm{D}$ ", teve como produto treze unidades de mapeamento: nove de Latossolo Vermelho Amarelo, duas de solos Gleizados e duas de solos Aluviais (Carvalho, 1990; Furian \& Pfeifer, 1986).

A gênese da cobertura pedológica da microbacia " $D$ " e sua relação com os processos de movimento de massa foi estudada por Furian et al.(1999 e 2002). Resumidamente, na alta vertente, da toposseqüência 2, os solos apresentam horizonte arenoso gibbsítico, proveniente do intemperismo in situ do material de origem. As estruturas do mineral original (feldspato) estão preservadas, resultando em horizonte gibbsítico com estrutura em box-work. Na parte mais ingreme da vertente, ainda sobre o horizonte gibbsítico, desenvolve-se um horizonte em blocos, caulinítico. Acima deste, estendem-se os horizontes microagregado e o grumoso. Na baixa vertente,

\footnotetext{
${ }^{2}$ A escala de Hazen (Pt-Co) é a unidade de medição de cor, que expressa o resultado como unidade Hazen (uH).
} 
- material gibbsítico está associado com minerais primários, o que indica uma mistura de material pedogenético proveniente de diferentes estágios de alteração. Isto sugere que o material da baixa vertente é de origem coluvionar e resultante de material retrabalhado do topo da vertente, pelos processos de escorregamento. Sobre este material gibbsítico desenvolve-se o horizonte microagregado.

A explicação que se dá ao escorregamento de material é que a porção da alta vertente com horizonte arenoso gibbsítico possui drenagem vertical. Enquanto, na porção mais íngreme da vertente, dominada por horizonte microagregado sobre horizonte argiloso caulinítico, a drenagem é lateral. Os resultados das curvas de retenção revelam que o horizonte microagregado retém rapidamente uma grande quantidade água durante um episódio de chuva intensa, sobrecarregando o terço inferior da vertente e gerando os escorregamentos.

Os estudos realizados por Furian et al.(1999 e 2002) revelaram a importância do conhecimento da dinâmica, vertical e lateral, da água no solo ao longo da vertente. Além de fornecerem informações que podem auxiliar no planejamento de manejo desses sistemas florestais, através da somatória dos resultados obtidos a respeito da vegetação, relevo, hidrologia e climatologia a fim de evitar novos processos erosivos e contribuir para a regeneração das áreas comprometidas.

Os estudos hidrológicos mostraram a importância da água de infiltração para o abastecimento do sistema, sobretudo nos meses mais secos. Sabe-se que a manutenção da cobertura vegetal e da porosidade solo são imprescindiveis para a infiltração da água da chuva (Arcova et al., 1998).

\subsection{Análise estrutural da cobertura pedológica}

A pedologia nasceu do reconhecimento da diferenciação vertical do solo uma vez que as escalas de observação de campo e dos meios de pesquisa empregados são as trincheiras e as tradagens. 
Os conhecimentos epistemológicos a respeito da pedologia foram divididos em três fases (Bocquier et al., 1984): a primeira fase pode ser resumida pela expressão fatores de formação (atuais)-solos (atuais), mostrando uma evolução atualista, funcional e geográfica. Na segunda fase, a expressão fatores de formação-solo, não é direta, pois estão inseridos os processos de formação (argiluviação, podzolização, ferralitização etc.), mostrando que o solo pode sofrer evolução contínua mesmo quando as condições do meio permanecem constantes. A atenção voltou-se para os mecanismos de transformação e transferência de matéria, qualificados e quantificados a partir de métodos estatísticos e analíticos como a geoquímica, a petrografia e a microanálise. Na terceira fase estão associados novos conceitos e métodos de análise espacial da cobertura pedológica. Esta espacialização é muito útil à cartografia dos solos, pois fornece subsídios mais seguros quanto à gênese e evolução das coberturas pedológicas. A partir desta nova concepção, os solos são entendidos como uma assembléia de compartimentos (volumes), os quais responderiam, dentre outros aspectos, pela circulação dos fluxos hídricos responsáveis pela modificação e evolução pedológica.

A compreensão da cobertura pedológica envolve três aspectos: os constituintes, a estrutura e a evolução (Ruellan et al., 1989).

Os constituintes dos solos são sólido, liquido e gasoso e estão organizados uns em relação aos outros originando as estruturas que são específicas do meio pedológico e equivalem como a anatomia de um ser vivo (morfologia). As estruturas são diferenciadas de acordo com a escala de observação, podendo ser:

1- organizações elementares: são os volumes pedológicos onde estão presentes os constituintes. São parcialmente vistas a olho nú ou com auxilio de microscópio. 
2- assembléias: são os volumes pedológicos caracterizados, sobre o terreno e pelo microscópio, pela presença de associação de certo número de organizações elementares.

3- horizontes: são volumes pedológicos, mais ou menos paralelos à superfície do terreno. Cada horizonte é descrito em termos de um ou mais tipos de assembléias e suas relações.

4- sistemas pedológicos: são volumes pedológicos onde são organizados os horizontes, verticalmente e lateralmente, na escala de unidade de relevo. Um sistema pedológico é descrito em termos de horizontes e de relações entre os horizontes. A definição morfológica do sistema pedológico deve encontrar sua confirmação apoiando-se em critérios geoquímicos e mineralógicos.

Uma cobertura pedológica está em contínua evolução, com a transformação de constituintes, de estruturas, de propriedades químicas, físicas e mineralógicas. Ocorrem também, transferências permanentes ou intermitentes de matéria sólida, líquida e gasosa. Ao final, em todos os níveis de organização, os constituintes e as estruturas assim como as propriedades e o funcionamento se substituem e se sucedem, traduzindo a história e a dinâmica atual da cobertura (Ruellan et al., 1989).

A análise estrutural, fundamentada por Boulet (1974), surgiu a partir da necessidade em pesquisar e adquirir rapidamente um conhecimento justo e tridimensional da organização e, na medida do possível, da dinâmica das coberturas pedológicas (Boulet et al., 1982a).

Boulet (1988) explicou a origem e o desenvolvimento da metodologia. No início dos anos 70 , sobreviviam as convenções cartográficas antigas, ao mesmo tempo em que se cristalizava o debate entre as idéias de evolução essencialmente vertical dos solos com aquelas que atribuíam à dinâmica lateral um papel maior na evolução das coberturas pedológicas. Naquela época, os documentos cartográficos cujo mapeamento e classificação baseavam-se na evolução vertical dos solos. Exceção era o trabalho de 
Bocquier (1971), limitado no Tchad, que mostrava de forma extremamente precisa as migrações laterais na toposseqüência estudada, propondo uma generalização de mecanismos que evidenciavam os conjuntos das coberturas intertropicais.

Boulet (1974) mostrou as contradições existentes nesta generalização. Nas coberturas de Haute-Volta, existem perfis com dinâmica essencialmente vertical resultantes da alteração das rochas subjacentes, com pouca variação lateral e existem perfis com dinâmica atual essencialmente lateral, com importante transferência de matéria de montante para jusante da vertente onde foi possivel encontrar as organizações e as diferenciações mineralógicas e geoquímicas evidenciadas por Bocquier (1971). O autor constatou e mostrou que as toposeqüênciass com dinâmica lateral onde predominam argilas montmorilonitas correspondem a sistemas de transformação das coberturas iniciais caoliníticas com dinâmica vertical. Esta transformação efetuou-se a partir da separação brusca do plasma caolinitico da cobertura inicial, a partir de uma frente de argiluviação. O plasma é transportado e confinado na baixa vertente, o que leva a neoformação de montmorilonita. As coberturas que atualmente estão em desequilibrio interno situam-se em ambiente mais seco, com estações contrastadas e recobertas por vegetação de savana, enquanto que a cobertura caolinítica estável está presente na porção mais úmida e recoberta por floresta.

Uma vez compreendidas as transformações das estruturas bi ou tridimensionais do solo, houve a necessidade de elaborar uma metodologia de pesquisa com um novo enfoque cartográfico, que representasse as distribuições espaciais e as relações genéticas entre as diversas partes da cobertura.

\subsubsection{Cartografia e análise estrutural}

Como colocado no item anterior, os pedólogos sempre privilegiaram a diferenciação vertical dos solos, devido a fatores históricos, pois a pedologia 
nasceu do reconhecimento da diferenciação vertical do solo e também, pelo fato de a escala de observação de campo e dos meios de pesquisa empregados serem as trincheiras e as tradagens. Em 1934, Milne lançou a idéia de catena, mostrando que existia uma diferenciação lateral expressa em termos de sucessão de solos ou de combinação, de polipédons contíguos. Outros trabalhos surgiram, mas permaneceram tributários em um meio que privilegiava a seção vertical (Boulet, 1988).

Apesar de serem notadas as diferenciações laterais em campo, não havia uma metodologia para elaborar documentos cartográficos que mostrassem essas diferenciações.

Os trabalhos que surgiram a partir do trabalho de Boulet (1974), modificaram profundamente a forma de estudar a dinâmica da cobertura pedológica, sobretudo sob o ponto de vista genético. A forma de estudar lateralmente o desenvolvimento do solo consta nos trabalhos de Boulet, 1974: Boulet et al., 1982 a e b; Ruellan, 1985 e Boulet 1988.

A vertente a ser estudada é previamente selecionada através de imagens de satélite. Escolhida a vertente são efetuadas tradagens com a finalidade de localizar os horizontes e suas transições e, em seguida, abrir as trincheiras. Faz-se uma tradagem a montante e outra a jusante. Em vertentes longas, estudam-se segmentos sucessivos de cerca de 50 metros. Faz-se tradagens intermediárias para localizar e desenhar os diferentes horizontes. Por exemplo: na primeira tradagem pode-se encontrar os horizontes $A, B$ e $C$. Na segunda tradagem pode-se encontrar horizontes diferentes como D, E, e horizontes iguais como A e B. O ponto intermediário, ponto 3, tentará encontrar o limite das transições. Quando não é possivel encontrar estes limites, faz-se tantos pontos intermediários quanto forem necessários. Esta operação de campo é registrada também em pedocomparador.

Com as anotações de campo e com auxillio das amostras do pedocomparador desenha-se o corte topográfico. As trincheiras abertas são cuidadosamente descritas. Após esta etapa, são coletadas amostras para 
análise em laboratório. O estudo ainda pode ser completado por mais tradagens a fim de estudar a estrutura espacial das características analíticas, desenhando-se as curvas de isodiferenciação.

As curvas de isodiferenciação constituem a projeção de um plano horizontal dos diversos horizontes pedológicos e fornecem informações novas e indispensáveis tanto das características estruturais como da dinâmica da cobertura.

A análise estrutural permite elaborar mapas em grande escala, no entanto o objetivo da pedologia é também fornecer mapas regionais. $\mathrm{Na}$ cartografia, representando uma bacia hidrográfica, a escala não é previamente escolhida, mas imposta pela escala de variação da organização da cobertura pedológica. Freqüentemente ocorre em escala 1:1.000, 1:500 e mesmo 1:100, evidentemente não é possível cobrir grandes superfícies com estas escalas. A dificuldade então, está em elaborar uma forma de mapeamento em escalas menores cujo mapeamento seja compreendido pelos profissionais que trabaham direta ou indiretamente com os solos.

Na Guiana Francesa este problema foi parcialmente resolvido, uma vez que existem trabalhos sistemáticos de análise estrutural naquela área, além da extensão territorial ser relativamente pequena. Constatou-se que, para aquela área existe um número de diferenciação de horizontes e que estes se organizam em seqüências repetidas, cujo significado genético é, em geral, evidente (Boulet, 1988).

\subsection{Micromorfologia no estudo dos horizontes B latossólicos}

Os horizontes subsuperficiais latossólicos $\left(B_{w}\right)$ são caracterizados por apresentar estágio avançado de intemperismo com alteração quase total dos minerais menos resistentes ao intemperismo e/ou dos argilominerais $2: 1$. As características morfológicas mais marcantes dos horizontes latossólicos são (i) a homogeneidade entre os suborizontes, (ii) a espessura mínima de 50 $\mathrm{cm}$, (iii) estrutura forte, muito pequena granular ou fraca, média a grande 
blocos subangulares, textura franco-arenosa ou mais fina e a cerosidade pouca e fraca, quando presente (Embrapa, 1999).

Os horizontes $B_{w}$ apresentam estrutura morfológica maciça ou em blocos subangulares fracos que se desfazem em microagregados de grau forte. Estes podem apresentar formas esféricas, ovais ou poliédricas de origem diversa (Buol \& Eswaran, 1978; Stoops, 1983).

As estruturas microagregadas dos solos ferralíticos vermelhos da República dos Camarões foram classificadas em: estruturais, zoogenéticas, complexas, reliquiais e ferríticas (Müller, 1977).

Os microagregados do tipo estrutural são formados pelo processo de micro estruturação (Müller, 1977; Stoops \& Buol, 1985; Vidal - Torrado et al. 1999). Os microagregados estruturais presentes nos solos ferralíticos da República dos Camarões são resultantes deste processo que ocorre nos horizontes profundos, caracterizados por apresentarem estrutura em blocos grandes moderados, textura argilosa, matizes avermelhados, maior densidade e baixa porosidade. O material original desses horizontes apresenta fábrica birrefringente manchada. A primeira etapa do processo de micro estruturação é a formação de reticulado sobre o material com fábrica birrefringente manchada, englobando áreas de aproximadamente 50 a 200 $\mu \mathrm{m}$ de diâmetro. A partir deste momento, surgem as fábricas birrefringentes estriadas reticuladas. Subseqüentemente, há aumento da birrefringência do reticulado $e$ as linhas se tornam levemente descoloridas, quando comparadas com os pequenos microagregados que começam a se formar no interior dos reticulados. Devido à evolução dos microagregados para formas arredondadas, as fábricas birrefringentes evoluem do reticulado para a forma circular, acompanhando as bordas dos microagregados que se formam. Nas zonas descoloridas formam-se microfissuras e os microagregados são formados. Na etapa final, as estruturas vão se tornando cada vez mais arredondadas e a porosidade fissural interpedal se desenvolve para porosidade do tipo empacotamento, típica de horizontes com estruturas microagregadas (Müller, 1977). 
Os microagregados zoogenéticos são formados pelo processo de bioturbação biológica (meso e microfauna) (Chauvel, 1977; Müller, 1977; Stoops, 1983; Eschenbrenner, 1986; Miklós, 1992 e 1993; Silva \& Vidal Torrado, 1999). A observação dos microagregados produzidos por cupins em amostras coletadas na Costa do Marfim e Congo e do material produzido por cupins em laboratório mostrou formas ovais a esféricas. A partir da similaridade entre as estruturas microagregadas dos latossolos e o material produzido pelos cupins, concluiu-se que a atividade dos cupins teve grande influência na formação dos solos tropicais. Este processo é denominado "bioagregação" (Eschenbrenner, 1986).

A cobertura pedológica estudada na região de Botucatu apresentou um conjunto de horizontes microagregados que se distribuem de montante a jusante. As evidências encontradas a respeito da origem biológica, no caso formigas e cupins, dessas estruturas, foram: presença sistemática de cupinzeiros endógenos em profundidade, no limite entre a alterita e o horizonte Bw; presença em abundância de litorelíquias ovais (100 a 1000 $\mu \mathrm{m})$ de fácies de alteritas mais profundas que as imediatamente subjacentes ao solo; a aptidão desses animais em fabricar microagregados ovais ("in vivo" ou "in vitro"); a própria forma oval destes microagregados; a grande variedade em tamanho e cor; a presença de micro partículas de carvão (< 30 $\mu \mathrm{m})$; o esqueleto interno, composto por grãos de quartzo inferiores a 100 $\mu \mathrm{m}$; a presença de orientações plásmicas periféricas; e a forte similaridade entre as estruturas microagregadas dos Latossolos e o material produzido pela fauna do solo no interior dos pedotúbulos de origem biológica e nos montículos de terra de formigueiros e cupinzeiros (Miklós, 1992 e 1993).

A fauna do solo (formigas, cupins e minhocas) desenvolve um papel na paisagem. Este papel está ligado diretamente aos seus comportamentos alimentar e construtor, os quais traduzem em ações que levam às modificações da cobertura pedológica, modificaçōes estas de origem física e química tais como: remonte vertical do material do solo e recobrimento de horizontes superficiais ("turn over - remonte biológico"); modificação da 
estrutura e da porosidade do solo (formação de agregados e formação de canais); e incorporação de matéria orgânica. Estas transformações são resultantes de processos de transporte de material pedológico em profundidade para a superfície e de material orgânico da superfície para o interior (Miklós, 1992 e 1993).

Os Latossolos Húmicos de área cratônica, localizada nos municípios de Machado e Alfenas (sul do estado de Minas Gerais), apresentaram evidências de estruturas microagregadas formadas pela atividade biológica. O comportamento da fauna do solo, descrito no parágrafo anterior, tem papel fundamental na melanização do horizonte superficial, contribuindo para a formação do horizonte $A$ húmico. Este horizonte é formado por um emaranhado de pedotúbulos, com preenchimento bruno escuro, que são identificados como de origem biológica devido ao grau de arredondamento (forte) e à presença de esqueleto relativamente fino (Silva \& Vidal - Torrado, 1999).

Há diminuição da densidade de biopedotúbulos em relação à área com 0 aumento da profundidade. Estes pedotúbulos biológicos preenchem totalmente o horizonte $A$, enquanto, no horizonte $A B$, representam $40 \%$ da área exposta, contra $25 \%$ em BA e apenas $10 \%$ em Bw. Tais observações, somadas às análises morfológicas e micromorfológicas, mostraram um espessamento gradual do horizonte húmico pela fauna do solo. Esta constrói canais e cavidades em profundidade, leva o material para as camadas superiores e, finalmente, preenche-as com agregados de origem biológica. Os agregados de origem biológica maiores que $1 \mathrm{~mm}$ são fragmentados em outros que se dispersam pela matriz do solo, o esqueleto e o plasma desses agregados são cimentados por substâncias orgânicas produzidas pela fauna do solo. Estes agregados cimentados e a decomposição do carvão presente no esqueleto conferem à matriz do solo um escurecimento. $O$ carvão, como componente do solo, além de influenciar decisivamente a melanização do horizonte $A$, pode ocorrer isoladamente (fragmentos maiores) ou 
constituindo o esqueleto fino de microagregados de origem biológica no horizonte $B_{w}$ (Silva \& Vidal - Torrado, 1999).

Microagregados de origem complexa são resultantes da aglutinação de microagregados menores (Stoops \& Buol, 1985).

Os microagredos reliquiais são herdados do material de origem (Müller, 1977; 1981; 1986) e podem estar relacionados a uma pedogênese policíclica envolvendo materiais retrabalhados (Stoops, 1967). A presença de nódulos de sesquióxidos, a maior parte concentrada em "stone-line", é uma das evidências mais marcantes de aloctonia. Estes nódulos podem ser fragmentos de laterita alóctone ou nódulos ferruginosos formados no perfil, mas que sofreram deslocamento relativo. A interrupção abrupta da fábrica interna, no limite dos nódulos, indica a fragmentaçäo, e a forma arredondada a subarredondada dos nódulos pode estar relacionada ao transporte (Stoops \& Buol, 1985).

Os microagregados ferríticos são formados a partir de processo de ferralitização anterior. Os processos geoquímicos que atuaram na formação destas estruturas iniciam-se a partir da alteração ferralítica com neoformação de material ferro-caulinítico que, após o desaparecimento dos minerais primários intemperizáveis, evolui para material caulino-gibbsitico. A fase ferro-caulinítica é caracterizada pela união de cristalitos de caulinita paralelos e ligados por pontes de ferro (Pedro et al., 1976), denominados policristalitos (Pedro, 1987). A fase caulino-gibbsítica corresponde à formação da estrutura microagregada típicas, decorrente da perda dos minerais primários intemperizáveis.

O mineral de argila dominante na composição dos microagregados é densamente empacotado, caulinítico, orientado ao acaso e apresenta baixa ordem estrutural. Os óxi-hidróxidos de ferro com baixa ordem estrutural (provavelmente ferrihidrita) presentes no espaço entre as partículas de caulinita têm importante papel na agregação das partículas de argila; a combinação de particulas de argilas orientadas ao acaso, a matéria orgânica 
e os agregados de ferro imprimem aos microagregados sua natureza isotrópica (Santos et al., 1989).

\subsection{Análise de imagem}

Os estudos micromorfológicos relacionados com a porosidade $e$ estrutura do solo que eram, originalmente descritivos (Kubiena, 1938; Bullock et al.), passaram a apresentar resultados quantitativos como a distribuição dos poróides; e a caracterização do tamanho, forma e orientação do poróide, com o uso de lâminas delgadas (Ringrose-Voase, 1991) ou blocos de solo (Colleuille, 1993).

A porosidade total compreende a estimativa da porosidade de uma imagem obtida a partir da relação entre o número de pixels da fase poral e o número de pixels da imagem binária (Hallaire \& Cointepas, 1993, Hallaire \& Curmi, 1998). Tratando-se de um parâmetro global, a porosidade total é insuficiente para descrever quantativamente o espaço poral. Por isso, observa-se a distribuição da porosidade total, a fim de refinar o estudo (Cooper, 1999).

A porosidade no solo desenvolve-se de forma tridimensional, ou seja, existe conexão entre os poros. Assim, a observação da porosidade no plano de corte de uma lâmina delgada, mostra a porosidade individualizada (Cooper, 1999). O termo poróide corresponde às zonas de intersecção da porosidade com o plano de corte da lâmina delgada (Moran et al., 1988). Dessa forma, os poróides são individualizados pelo Noesis-Visilog 5.4 , o que permite a definição dos parâmetros da forma dos poróides (Cooper, 1999). 


\section{CARACTERIZAÇÃO E ORGANIZAÇÃO DE UMA TOPOSSEQÜÊNCIA DE SOLOS NO PARQUE ESTADUAL DA SERRA DO MAR - SP}

\section{RESUMO}

A região do Núcleo Cunha-Indaiá, de clima tropical úmido, é muito susceptivel a movimentos de massa, que, muitas vezes, possuem dimensões catastróficas. Por isso, o conhecimento do funcionamento do solo é importante a fim de planejar o uso racional de áreas similares e/ou recuperar aquelas já degradadas. Este trabalho teve como objetivo caracterizar e estudar a organização de uma toposseqüência de solos, bem como classificámlos. A toposseqüência em questão localiza-se na microbacia "B" do Núcleo Cunha-Indaiá, no Parque Estadual da Serra do Mar - SP. O estudo foi realizado a partir de sondagens em quinze pontos e de trincheiras em cinco locais. Realizado o estudo detalhado do perfil, foram coletadas amostras deformadas para caracterização a partir de parâmetros físicos, químicos e mineralógicos. Estes solos desenvolvidos sobre rocha metamórfica foram classificados, de montante para jusante, como Latossolo Amarelo Distrófico típico (perfil 5), Latossolo Amarelo Distrófico câmbico (perfil 6), Latossolo Amarelo Distrófico argissólico (perfil 13), Latossolo Amarelo Distrófico argissólico (perfil 4) e Cambissolo Háplico Alumínico típico (perfil 2). A textura desses solos é muito variável, os horizontes latossólicos apresentaram textura entre argilo-arenosa e franco-argiloarenosa, argilo-arenosa e argilosa; os horizontes prismáticos entre argiloarenosa, argilosa e franco-argilosa. As características mineralógicas do solo indicam diferentes estágios de intemperismo como: caulinita, vermiculita, 
mica e VHE. As características químicas são alta acidez ativa, potencial e trocável; baixos teores de $\mathrm{Ca}, \mathrm{Mg}, \mathrm{K}$ e Na; baixa saturação por bases ( $\mathrm{V} \%$ ); as concentrações de $P$ disponivel diminuíram em profundidade; os teores de $S$ não se mostraram limitantes; os teores de micronutrientes $(\mathrm{B}, \mathrm{Cu}, \mathrm{Fe}, \mathrm{Mn}$ e $\mathrm{Zn}$ ) foram maiores nos horizontes superficiais; os elementos traço $\mathrm{Cd}, \mathrm{Cr}$, $\mathrm{Ni}$ e $\mathrm{Pb}$ quando detectados pelo método empregado, apresentam-se em baixas concentrações e a CTC apresentou valores mais altos nos horizontes mais ricos em MOS. 


\section{CHARACTERIZATION AND ORGANIZATION OF A SOIL. TOPOSEQUENCE IN THE "PARQUE ESTADUAL DA SERRA DO MAR - SP"}

\section{ABSTRACT}

The area of the "Núcleo Cunha-Indaiá", with humid tropical climate, it is very susceptible to mass movements, that a lot of times have catastrophic dimensions. Therefore, the soil dynamic knowledge is important to plan the rational use of the areas similar and to restore those already degraded. This work aimed to characterize and to study the organization of a soil toposequence, as well as to classify them. The soil toposequence studied is located in the small watersheds " B " of the "Núcleo Cunha-Indaiá", in the "Parque Estadual da Serra do Mar" - SP. The study was carry out in fifteen points and five trenches. For detailed study of the profile, the samples were collected for physical, chemical and mineralogical characterization. These soils developed on metamorphic rock were classified (Soil Taxonomy), from the top to the base, like Typic Hapludoxs (profile 5), Typic Hapludoxs (profile 6), Typic Hapludoxs (profile 13), Typic Hapludoxs (profile 4) and Fragic Dystrudepts (profile 2). The texture of those soils is very variable, the latossol horizons presented texture between argilo-sandy and franc-argilo-sandy, argilo-sandy and loamy; the prismatic horizon among argilo-sandy, loamy and franc-loamy. The soil mineralogical characteristics indicate different weathering stage like: kaolinite, vermiculite, mica and VHE. The chemical 
characteristics were high active, potential and exchangeable acidity; low $\mathrm{Ca}$, $\mathrm{Mg}, \mathrm{K}$ and $\mathrm{Na}$ contents; low base saturation; the available $\mathrm{P}$ content decreased in depth; the $S$ contents were not critical; the micronutrient contents ( $\mathrm{B}, \mathrm{Cu}, \mathrm{Fe}, \mathrm{Mn}$ and $\mathrm{Zn}$ ) were higher in the superficial horizons; the trace elements $\mathrm{Cd}, \mathrm{Cr}, \mathrm{Ni}$ and $\mathrm{Pb}$ have low contents, when detected by the used method; and CEC values were higher in the richest horizons in SOM (soil organic matter).

\subsection{INTRODUÇÃO}

As florestas tropicais úmidas, como a Mata Atlântica, têm sido destruídas, sobretudo, nos tempos modernos, devido ao aumento da população, da demanda de recursos naturais, das atividades agrosilvipastoris, além da expansão urbana e industrial. A redução da biodiversidade, a perda de solo por processos erosivos, o assoreamento dos canais fluviais, o aumento de inundações e o abaixamento do nível dos lençóis freáticos são algumas das conseqüências do desmatamento (Arcova \& Cicco, 1997; Domingues et al., 2001; Arcova et al., 1998). Desse modo, a conservação do solo, bem como a preservação e a recuperação da Mata Atlântica, sobretudo em áreas de captação de água para consumo humano, são medidas apropriadas no manejo de bacias hidrográficas, imprescindíveis para reverter ou amenizar as conseqüências do desmatamento (Fujieda et al, 1997).

O conhecimento do funcionamento e da dinâmica da interface solofloresta tem papel fundamental na execução e implementação de políticas públicas e estratégias para a recuperação, manutenção e o desenvolvimento sustentável. Com isso, a caracterização de uma toposseqüência de solos localizada na microbacia "B" no Núcleo Cunha-Indaiá do Parque Estadual da Serra do Mar - SP, poderá contribuir para o estabelecimento de ações que visem o uso e a sustentabilidade de áreas similares. 
O objetivo desta pesquisa foi classificar e caracterizar cinco perfis de solos, de uma toposseqüência, a partir de estudos morfológicos, mineralógicos, químicos e físicos.

\subsection{Material e métodos}

\subsubsection{Localização e caracterização da área de estudo}

O Núcleo Cunha-Indaiá, do Parque Estadual da Serra do Mar, está localizado a nordeste do Estado de São Paulo, entre as coordenadas geográficas $23^{\circ} 13^{\prime} 28^{\prime \prime}$ e $23^{\circ} 16^{\prime} 10^{\prime \prime} \mathrm{S}$ e $45^{\circ} 02^{\prime} 53^{\prime \prime}$ e $45^{\circ} 05^{\prime} 15^{\prime \prime} \mathrm{W}$ (Figura1). Com área total de 2.854 ha e altitudes entre 800 e $1.500 \mathrm{~m}$ (Fujieda et al., 1997), o Núcleo Cunha-Indaiá está inserido no alto e médio vale do rio Paraibuna, no Planalto do Paraitinga (Furian \& Pfeifer, 1986). No Núcleo localiza-se a microbacia experimental " $B$ " (Figura 9), onde foi selecionada uma toposseqüência para o desenvolvimento dos estudos físicos, químicos e mineralógicos.

O clima é do tipo Cwa (classificação Köppen), mesotérmico de inverno seco com temperaturas no inverno inferiores a $18^{\circ} \mathrm{C}$ e no verão superiores a $22^{\circ} \mathrm{C}$ (Furian \& Pfeifer, 1986). A temperatura média anual é de $16,5^{\circ} \mathrm{C}$ e as médias anuais máxima e mínima são, respectivamente, de $20,6^{\circ} \mathrm{C}$ e $6,6^{\circ} \mathrm{C}$ (inverno) e de $26,3^{\circ} \mathrm{C}$ e $16,0^{\circ} \mathrm{C}$ (verão) (Fujieda et al., 1997). No mês mais seco o total de precipitação pluvial não ultrapassa $30 \mathrm{~mm}$, sendo a média anual entre 1.100 e $1.700 \mathrm{~mm}$, com periodo chuvoso entre outubro a março (Furian \& Pfeifer, 1986).

O substrato geológico pertence ao Complexo Cristalino, do período Pré-Cambriano e possui litologia constituída por granitos, gnaisses e migmatitos (São Paulo, 1981a).

A área de estudo está inserida na província geomorfológica do Planalto Atlântico e ocupa a zona geomorfológica do Planalto do Paraitinga, com relevo apresentando-se num estágio mais avançado da evolução 
geomorfológica, onde as formas do tipo mar de morros evoluiu para formas mamelonares, comuns do Planalto do Paraitinga (São Paulo, 1981b).

A vegetação original foi classificada como Floresta Latifoliada Perenifólia - Mata Atlântica que se desenvolve em altitudes superiores a 1.000 m (Leitão Filho, 1982).

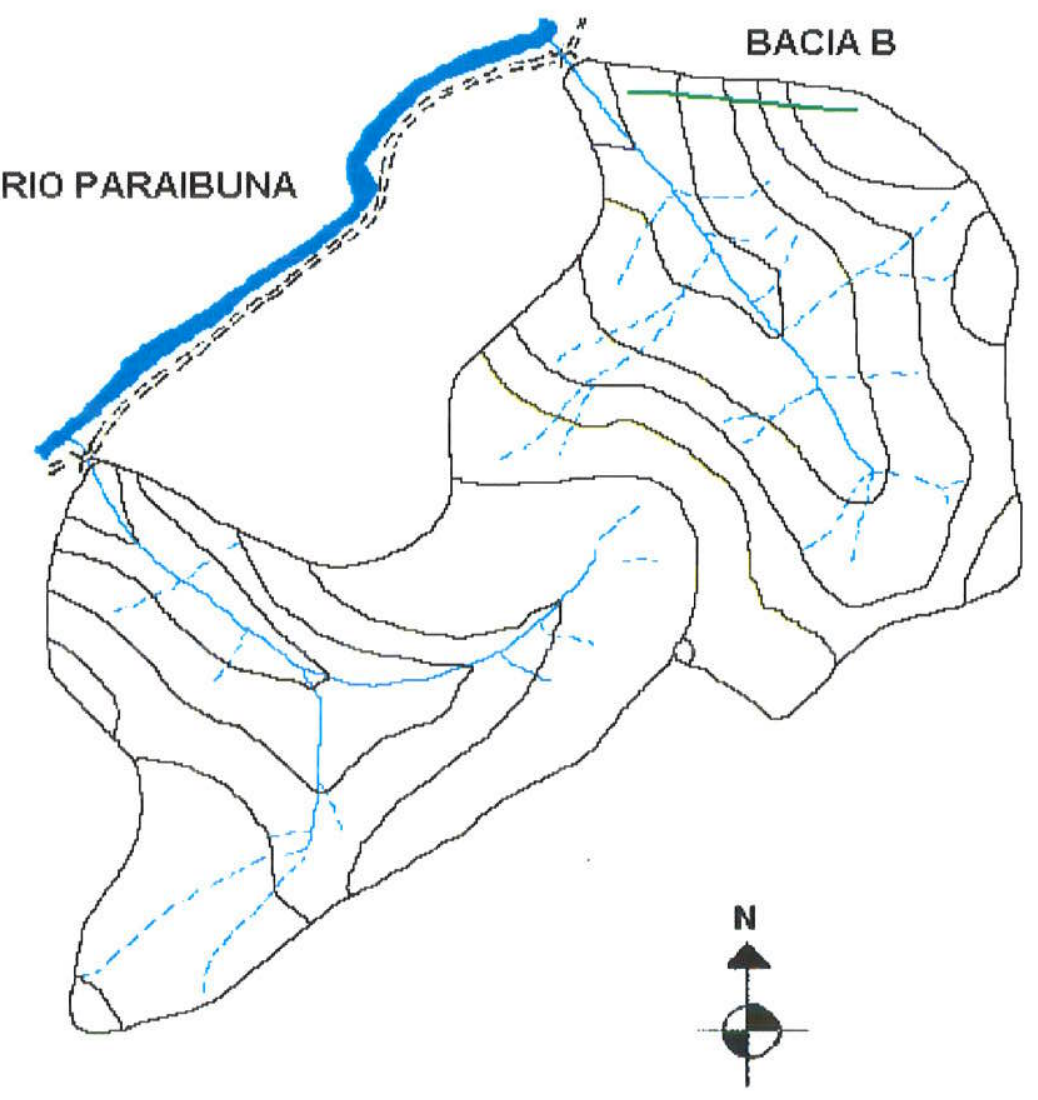

\section{LEGENDA:}

Vertente estudada
Rio perene:

Rio intermitente:

Rio principal:

Ponte:

Via năo pavimentada: ニニーニニニニ

Escala:

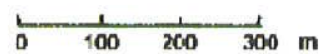

Fonte: IGc (1978) Arcova (1996).

Figura 9 - Localização da vertente estuda, modificado de 


\subsubsection{Descrição morfológica da cobertura pedológica}

A caracterização detalhada da cobertura pedológica foi realizada segundo 0 procedimento da análise estrutural bidimensional proposto por Boulet et al. (1982 a e b). Desse modo, foram realizadas sondagens ao longo da vertente visando localizar a presença dos diferentes horizontes, bem como seu aparecimento e desaparecimento. Os trabalhos foram divididos em etapas: (i) realização de quinze pontos de sondagem para estabelecer a locação das trincheiras; (ii) abertura de cinco trincheiras nos pontos que apresentaram as seqüências mais representativas, selecionadas a partir da etapa (i); (iii) descrição morfológica dos perfis. Na primeira etapa foram realizadas as descrições de cor e textura do solo, o qual foi organizado em pedocomparadores, segundo o número e a profundidade da sondagem, a fim de representar a anatomia da distribuição dos solos ao longo da topossequência; na segunda foram selecionados os pontos mais representativos para a abertura de trincheiras e na terceira foi realizada a descrição morfológica dos perfis de solo de acordo com os métodos apresentados por Lemos \& Santos (1984).

\subsubsection{Análises mineralógica, química e física}

Foram coletadas amostras representativas de solo de todos os horizontes dos cinco perfis estudados. As amostras foram secas ao ar e passadas por peneira com malha de $2 \mathrm{~mm}$, obtendo-se a fração terra fina seca ao ar (TFSA).

A investigação mineralógica foi realizada mediante o emprego de métodos instrumentais de difratometria de raios- $X(D R X)$ e de análise térmica diferencial e gravimétrica (ATD/ATG).

As análises por DRX foram realizadas em amostras totais e na fração argila dos diferentes horizontes dos perfis de solo. As amostras totais foram obtidas após a moagem até $0,106 \mathrm{~mm}$ da TFSA e preparadas lâminas do material em pó, as quais foram levadas ao difratômetro de raios- $x$. A fração argila foi obtida a partir de amostras de TFSA previamente tratada de acordo 
com a metodologia de Whittig \& Allardice (1986), com algumas adaptações. A fração argila deferrificada em solução foi separada em três partes: (i) natural, (ii) saturada com $\mathrm{K}^{+}(\mathrm{KCl})$ para posterior tratamento térmico $\left(110^{\circ}\right.$, $350^{\circ}$ e $\left.550^{\circ} \mathrm{C}\right)$ e (iii) saturada com $\mathrm{Mg}^{2+}(\mathrm{MgCl})$ para posterior saturação com etileno-glicol. As diferentes frações foram depositadas sobre lâminas de vidro e levadas ao equipamento de DRX.

O difratômetro Philips PW 1877 foi operado em potencial de 40kV, corrente de $40 \mathrm{~mA}$, fonte de $\mathrm{Cu}$ (radiação $\mathrm{K} \alpha, \lambda=1,54186 \AA$ ), uso de monocromador para eliminação da radiação $\mathrm{K} \beta$, varredura em passo de $0,02^{\circ}(2 \theta)$, com um tempo de acumulação de 1 s por passo, e amplitude de varredura de $3^{\circ}-90^{\circ}(2 \theta)$ para amostras pulverizadas e de $3^{\circ}-65^{\circ}(2 \theta)$ para a fração argila.

Foi utilizado o método instrumental de ATD/TG visando qualificar e semi-quantificar a caulinita e a gibbsita presentes na fração argila. Para isso, utilizou-se a metodologia proposta por Tan et al. (1986), modificada. Foram colocadas $20 \mathrm{mg}$ da fração argila deferrificada em porta amostra de alumina e submetido a ciclo de aquecimento e resfriamento. $O$ equipamento Shimadzu DTG-60H/Simultaneous DTA/TG foi operado em ciclo de aquecimento/resfriamento a partir da temperatura ambiente até $1.300{ }^{\circ} \mathrm{C}$ com razão de aquecimento de $10^{\circ} \mathrm{C} / \mathrm{min}$ e atmosfera $\mathrm{N}_{2}$.

$\mathrm{O} \mathrm{pH}$ do solo foi determinado por potenciometria, em solução de $\mathrm{CaCl}_{2} 0,01 \mathrm{~mol} \mathrm{~L}-1, \mathrm{KCl} 1 \mathrm{~mol} \mathrm{~L}^{-1}$ e $\mathrm{H}_{2} \mathrm{O}$, usando uma suspensão com relação solo:solução de 1,0:2,5 (m:v). As concentrações de $\mathrm{H}+\mathrm{Al}$ (acidez potencial) foram determinadas por titulação com solução padronizada de $\mathrm{NaOH} 0,025 \mathrm{~mol} \mathrm{~L}^{-1}$ de extratos de TFSA obtidos com solução $\mathrm{Ca}\left(\mathrm{CH}_{3^{-}}\right.$ $\mathrm{COO}_{2} \quad 0,5 \mathrm{~mol} \mathrm{~L}^{-1}$ a $\mathrm{pH} 7,0$. As concentrações trocáveis de Al (acidez trocável), Ca e $\mathrm{Mg}$ foram determinadas em extratos de TFSA obtidos com solução $\mathrm{KCl} 1,0 \mathrm{~mol} \mathrm{~L}^{-1}$. Foram determinadas as concentrações de $\mathrm{Al}$ trocável por titulação com solução padronizada de $\mathrm{NaOH} 0,025 \mathrm{~mol} \mathrm{~L}^{-1}$ e as concentrações de $\mathrm{Ca}$ e $\mathrm{Mg}$ foram obtidas mediante leitura por 
espectrometria de absorção atômica com atomização em chama (EAAchama). As concentrações de $\mathrm{Na}, \mathrm{K}$ e $\mathrm{P}$ foram determinadas em extratos de TFSA obtidos com solução Mehlich-1 $\left(\mathrm{HCl} \mathrm{0,05} \mathrm{mol} \mathrm{L}^{-1}+\mathrm{H}_{2} \mathrm{SO}_{4} \quad 0,0125 \mathrm{~mol}\right.$ $\mathrm{L}^{-1}$ ), mediante leitura por espectrofotometria de emissão em chama (EEC) para $\mathrm{Na}$ e $\mathrm{K}$ e por espectrofotometria de absorção molecular (EAM) para $\mathrm{P}$. Foi empregada relação solo:solução de 1:10 (m:v) para as determinações analíticas de $\mathrm{Al}, \mathrm{Ca}, \mathrm{Mg}, \mathrm{K}, \mathrm{Na}$ e $\mathrm{P}$. As concentrações de $\mathrm{S}$ disponível foram extraídas por solução fosfato monocáicico $0,01 \mathrm{~mol} \mathrm{~L}^{-1} \mathrm{e}$ as determinações foram realizadas por turbidimetria (Fox et al., 1987). As concentrações de $B$ disponivel foram extraídas por solução $0,006 \mathrm{~mol} \mathrm{~L}^{-1}$ de $\mathrm{BaCl}_{2}$ aquecido em microondas $e$ as determinações foram realizadas por espectroscopia de emissão óptica com plasma de argônio acoplado indutivamente (ICP-OES) (Abreu et al., 1994). As concentrações disponíveis de metais pesados ( $\mathrm{Cu}$, $\mathrm{Fe}, \mathrm{Mn}, \mathrm{Zn}, \mathrm{Cd}, \mathrm{Cr}, \mathrm{Ni}$ e $\mathrm{Pb}$ ) foram determinadas em extratos de TFSA obtidos com solução DTPA-TEA (ácido dietilenotriaminopentaacético 0,005 mol L-1 + trietanolamina $0,1 \mathrm{~mol} \mathrm{~L}^{-1}+\mathrm{CaCl}_{2} 0,01 \mathrm{~mol} \mathrm{~L}^{-1}$ ) a pH 7,3 (Lindsay \& Norvell, 1978), mediante leitura por ICP-OES. As concentrações de carbono total (CT) e nitrogênio total (NT) foram obtidas por combustão a seco (Nelson \& Sommers, 1996), após as amostras de TFSA serem moídas e peneiradas em peneira de malha de $0,15 \mathrm{~mm}$.

A partir dos resultados de análises de solo foram calculados os valores de: (i) capacidade de troca de cátions a pH 7,0- CTC (CTC $=\mathrm{Ca}+$ $\mathrm{Mg}+\mathrm{K}+\mathrm{Na}+\mathrm{H}+\mathrm{Al}$ ); (ii) $\mathrm{CTC}$ efetiva (CTCe $=\mathrm{Ca}+\mathrm{Mg}+\mathrm{K}+\mathrm{Na}+\mathrm{Al}$ ); (iii) saturação por bases $-\mathrm{V}(\mathrm{V}=\mathrm{Ca}+\mathrm{Mg}+\mathrm{K}+\mathrm{Na}) \times 100 / \mathrm{CTC})$; (iv) saturação por alumínio $-\mathrm{m}(\mathrm{m}=\mathrm{Al} / \mathrm{CTCe})$ (Tabelas 5 e 6$)$.

A determinação da granulometria do solo foi realizada pelo o método da pipeta (Embrapa, 1986). 


\subsection{Resultados e discussão}

\subsubsection{Análise estrutural bidimensional}

O procedimento de análise estrutural da cobertura pedológica teve como resultado oito horizontes (Figura 10) que se organizam lateralmente da seguinte forma: os horizontes superficiais grumoso bruno escuro e o microagregado bruno, presentes ao longo de toda a vertente, sofrem ligeiras modificações em alguns atributos, muito provavelmente relacionadas à posição ocupada na toposseqüência e a movimentos coluvionares superficiais. Os horizontes prismáticos, presentes no segmento íngreme da vertente, iniciam-se em forma de cunha a $14,8 \mathrm{~m}$ a jusante do perfil $6 \mathrm{e}$ desaparecem, também em forma de cunha, a $15,0 \mathrm{~m}$ a jusante do perfil 4 . $O$ horizonte de alteração bruno oliva claro ocorre no segmento inferior da vertente, entre as tradagens 1 e 9 . No topo da vertente ocorrem os horizontes microagregado bruno avermelhado e de alteração violácea. $O$ horizonte de alteração (isoalterita) ocorre no segmento mais ingreme da vertente.

O material da cobertura pedológica presente a partir da parte mais íngreme da vertente, é uma mistura de materiais da alteração "in situ" e de retrabalhados por processos de movimentos de massa. Por isso, estes últimos são similares àqueles presentes no topo (Furian et al., 1999). A cobertura pedológica do topo da vertente possui somente alteração "in situ" do gnaisse.

\subsubsection{Descrição morfológica}

O resultado da descrição morfológica detalhada dos perfis das cinco trincheiras, de montante a jusante, está organizado na tabela 2.

As particularidades de cada horizonte são:

\section{Perfil 5}


O horizonte A apresenta estrutura grumosa inferior a $1 \mathrm{~cm} \mathrm{e}$ porosidade tubular relacionada à atividade biologia e à presença de muitas raízes. A transição é gradual.

No horizonte BA há predomínio de estrutura em blocos subangulares com subestrutura microagregada bem desenvolvida e, em alguns locais, grumosa. Porosidade tubular entre microagregados bem desenvolvida, também evidenciada nos estudos micromorfológicos (Figura 10). Presença de muitas raízes. A transição é gradual.

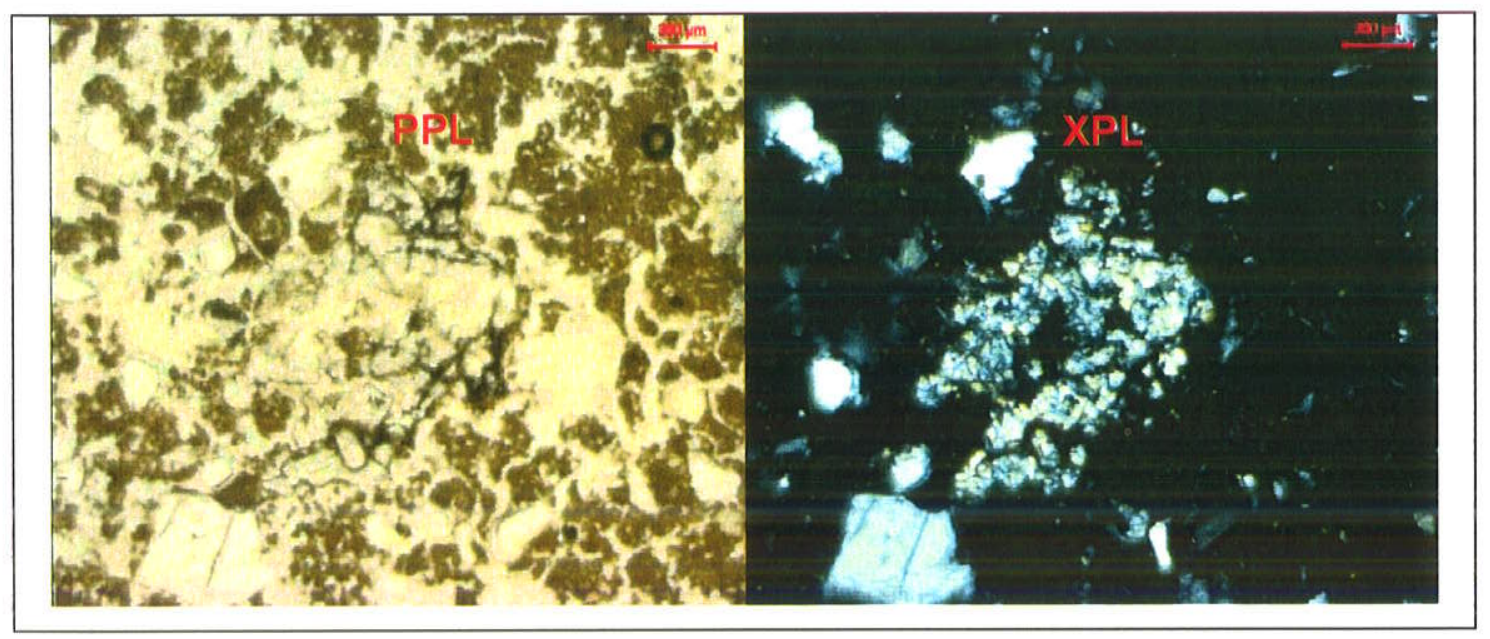

Figura 10 - Fotomicrografias mostrando estrutura microagregada com tendência à formação de blocos subangulares. XPL designa as fotomicrografias obtidas com nicóis cruzados (polarizador e analisador inseridos) e a sigla PPL aquelas obtidas com a luz polarizada em único plano (polarizador inserido).

A porosidade do horizonte Bw1 é fissural entre os agregados e tubular bem desenvolvida entre microagegado. Presença de muitas raízes. A partir de $82 \mathrm{~cm}$ de profundidad e apresenta concentração de blocos de até 5 $\mathrm{cm}$, muitos de cor violácea com pontuações de cor branca e amarelo-clara, provavelmente gibbsíticos. Transição abrupta.

O horizonte Bw2 possui porosidade tubular bem desenvolvida entre microagregados, que a partir de $135 \mathrm{~cm}$ torna-se menos desenvolvida. Presença de grãos de quartzo centimétricos que se quebram. Transição abrupta marcada por linha de rocha alterada branca. 


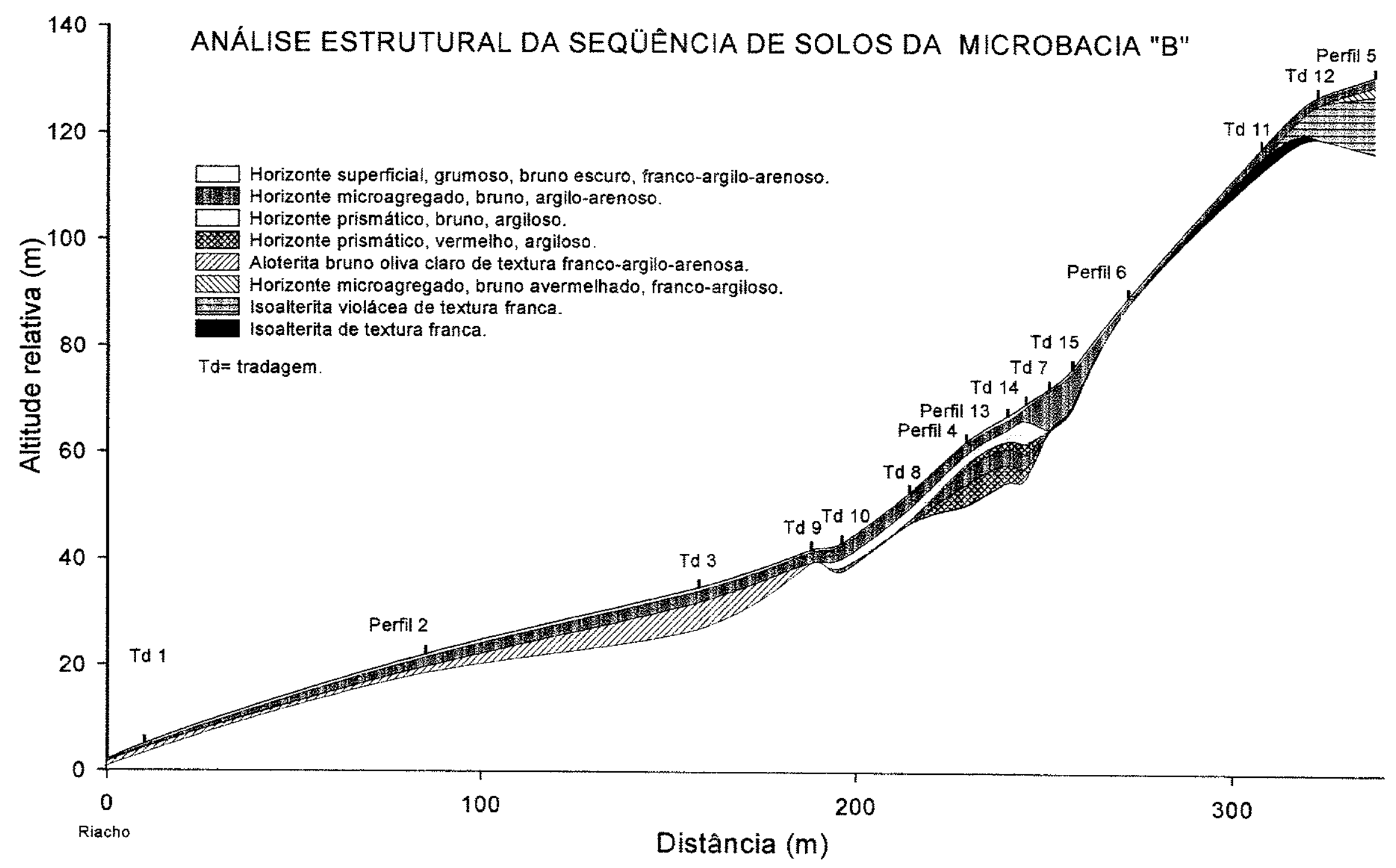

Figura 11 - Distribuição dos principais horizontes ao longo da toposseqüência. 
Tabela 2 - Características morfológicas dos perfis estudados

\begin{tabular}{|c|c|c|c|c|c|c|c|}
\hline \multirow[t]{2}{*}{ Horizonte } & \multirow{2}{*}{$\begin{array}{l}\text { Profundidade } \\
\text { (cm) }\end{array}$} & \multirow{2}{*}{$\begin{array}{c}\text { Cor } \\
\text { (Munsell) } \\
\text { Úmida }\end{array}$} & \multirow[t]{2}{*}{ Estrutura(ग) } & \multicolumn{3}{|c|}{ Consistência $^{(2)}$} & \multirow[t]{2}{*}{ Cerosidade (3) } \\
\hline & & & & Seca & Úmida & Molhada & \\
\hline \multicolumn{8}{|c|}{ Perfil 5 - Latossolo Amarelo Distrófico típico } \\
\hline A & $0-15$ & $7,5 Y R 3 / 3$ & Fraca média grumosa & Macia & $\begin{array}{l}\text { Muito } \\
\text { friável }\end{array}$ & $\begin{array}{l}\text { Não plást. / } \\
\text { não peg. }\end{array}$ & - \\
\hline $\mathrm{BA}$ & $15-46$ & $7,5 Y R 4 / 4$ & $\begin{array}{l}\text { Fraca méd. bl. subang. / } \\
\text { forte peq. microag. }\end{array}$ & Macia & Friável & $\begin{array}{l}\text { Lig. plást. / lig. } \\
\text { peg. }\end{array}$ & - \\
\hline Bw1 & $46-103$ & $6 Y R 5 / 6$ & $\begin{array}{l}\text { Fraca gr. bl. subang. I } \\
\text { forte peq. microag. }\end{array}$ & $\begin{array}{l}\text { Muito } \\
\text { dura }\end{array}$ & Firme & $\begin{array}{l}\text { Lig. plást. / lig. } \\
\text { peg. }\end{array}$ & - \\
\hline Bw2 & $103-160$ & 2,5 YR $4 / 6$ & $\begin{array}{l}\text { Fraca gr. bl. subang. / } \\
\text { forte peq. microag. }\end{array}$ & $\begin{array}{l}\text { Muito } \\
\text { dura }\end{array}$ & Firme & $\begin{array}{l}\text { Lig. plást. / lig. } \\
\text { peg. }\end{array}$ & - \\
\hline $\mathrm{BC}$ & $160-210$ & $10 R 4 / 6$ & Fraca méd. Bl. subang. & Macia & $\begin{array}{l}\text { Muito } \\
\text { friável }\end{array}$ & $\begin{array}{l}\text { Não plást. / } \\
\text { não peg. }\end{array}$ & - \\
\hline C & $210-240+$ & $10 R 3 / 6$ & Maciça & Solta & $\begin{array}{l}\text { Muito } \\
\text { friável }\end{array}$ & $\begin{array}{l}\text { Não plást. / } \\
\text { não peg. }\end{array}$ & - \\
\hline \multicolumn{8}{|c|}{ Perfil 6 - Latossolo Amarelo Distrófico câmbico } \\
\hline A & $0-26$ & 7,5 YR $2 / 3$ & Fraca peq. Grumosa & Macia & $\begin{array}{l}\text { Muito } \\
\text { friável }\end{array}$ & $\begin{array}{l}\text { Não plást. / } \\
\text { nâo peg. }\end{array}$ & - \\
\hline $\mathrm{BA}$ & $26-55$ & 7,5 YR $4 / 4$ & $\begin{array}{l}\text { Fraca méd. bl. subang. / } \\
\text { forte muito peq. Microag. }\end{array}$ & Macia & $\begin{array}{l}\text { Muito } \\
\text { friável }\end{array}$ & $\begin{array}{l}\text { Não plást. / } \\
\text { não peg. }\end{array}$ & - \\
\hline Ew & $55-160+$ & $\begin{array}{r}7,5 Y R 4 / 6 \\
\text { Perfil }\end{array}$ & $\begin{array}{l}\text { Fraca méd. bl. subang. / } \\
\text { forte muito peq. Microag. } \\
13 \text { - Latossolo Amarelo Dis }\end{array}$ & $\begin{array}{l}\text { Macia } \\
\text { rófico ars }\end{array}$ & $\begin{array}{l}\text { Mutto } \\
\text { friável } \\
\text { issótico }\end{array}$ & $\begin{array}{l}\text { Não plást. / } \\
\text { não peg. }\end{array}$ & - \\
\hline A & $0-24$ & 10YR 4/4 & Fraca peq. Grumosa & Macia & $\begin{array}{l}\text { Muito } \\
\text { friável }\end{array}$ & $\begin{array}{l}\text { Lig. plást. / lig. } \\
\text { peg. }\end{array}$ & - \\
\hline $\mathrm{BA}$ & $24-61$ & 10YR $4 / 6$ & $\begin{array}{l}\text { Fraca méd. bl. subang. I } \\
\text { forte muito peq. Microag. }\end{array}$ & Macia & $\begin{array}{l}\text { Muito } \\
\text { friável }\end{array}$ & Plást. / peg. & - \\
\hline Bw1 & $61-95$ & $7,5 Y R$ 5/6 & $\begin{array}{l}\text { Fraca méd. a gr. bl. } \\
\text { subang. / forte muito } \\
\text { peq. microag. }\end{array}$ & $\begin{array}{l}\text { Lig. } \\
\text { Dura }\end{array}$ & Firme & Plást. / peg. & - \\
\hline Bw2 & $95-148$ & $7,5 Y R 5 / 6$ & $\begin{array}{l}\text { Mod. méd. A gr. bi. } \\
\text { subang. / forte muito } \\
\text { peq. microag. }\end{array}$ & Dura & Firme & Plást. / peg. & Fraca e pouca \\
\hline Bni1 & $148-201$ & $7,5 Y R$ 5/8 & Mod. méd. a gr. prism. & $\begin{array}{l}\text { Muito } \\
\text { dura }\end{array}$ & $\begin{array}{l}\text { Muito } \\
\text { firme }\end{array}$ & $\begin{array}{l}\text { Plást. / muito } \\
\text { peg. }\end{array}$ & Mod. e comum \\
\hline Bni1/Bni2 & $201-225$ & $6 Y R 5 / 8$ & Forte gr. prism. & $\begin{array}{l}\text { Muito } \\
\text { dura }\end{array}$ & $\begin{array}{l}\text { Muito } \\
\text { firme }\end{array}$ & $\begin{array}{l}\text { Muito plást. / } \\
\text { muito peg. }\end{array}$ & Mod. e comum \\
\hline Bni2 & $225+$ & 5YR 5/8 & Forte gr. prism. & $\begin{array}{l}\text { Muito } \\
\text { dura }\end{array}$ & $\begin{array}{l}\text { Muito } \\
\text { firme }\end{array}$ & $\begin{array}{c}\text { Muito plást. / } \\
\text { muito peg. }\end{array}$ & $\begin{array}{c}\text { Mod. e } \\
\text { abundante }\end{array}$ \\
\hline
\end{tabular}


Tabela 2 - Características morfológicas dos perfis estudados

\begin{tabular}{|c|c|c|c|c|c|c|c|}
\hline \multirow[t]{2}{*}{$\mathrm{Hz}$} & \multirow{2}{*}{$\begin{array}{l}\text { Prof. } \\
\text { (cm) }\end{array}$} & \multirow{2}{*}{$\begin{array}{l}\text { Cor } \\
\text { (Munsell) } \\
\text { Úmida }\end{array}$} & \multirow[t]{2}{*}{ Estrutura (1) } & \multicolumn{3}{|c|}{ Consistência $^{(2)}$} & \multirow[t]{2}{*}{ Cerosidade ${ }^{(3)}$} \\
\hline & & & & Seca & Umida & Molhada & \\
\hline \multicolumn{8}{|c|}{ Perfil 4 - Latossolo Amarelo Distrófico argissólico } \\
\hline A & $0-11$ & $7,5 Y R 3 / 2$ & Fraca peq. Grumosa & Macia & $\begin{array}{l}\text { Muito } \\
\text { friável }\end{array}$ & $\begin{array}{l}\text { Lig. plást. / tig. } \\
\text { peg. }\end{array}$ & - \\
\hline BA & $11-27$ & 7,5YR 4/4 & $\begin{array}{l}\text { Fraca peq. bl. subang. I } \\
\text { forte muito peq. microag. }\end{array}$ & Macia & $\begin{array}{l}\text { Muito } \\
\text { friável }\end{array}$ & $\begin{array}{l}\text { Lig. plást. / lig. } \\
\text { peg. }\end{array}$ & - \\
\hline Bw1 & $27-60$ & 10YR 4/6 & $\begin{array}{l}\text { Fraca peq. bl. subang. I } \\
\text { forte muito peq. microag. }\end{array}$ & Dura & Firme & Plást. / peg. & - \\
\hline Bw2 & $60-100$ & $7,5 Y R 5 / 6$ & $\begin{array}{l}\text { Mod. méd. A gr. bl. } \\
\text { subang. / forte muito } \\
\text { peq. microag. }\end{array}$ & Dura & Firme & $\begin{array}{l}\text { Plást. / muito } \\
\text { peg. }\end{array}$ & Fraca e pouca \\
\hline Bni1 & $100-207$ & $7,5 Y R 5 / 8$ & Mod. méd. a gr. prism. & $\begin{array}{l}\text { Muito } \\
\text { dura }\end{array}$ & $\begin{array}{l}\text { Muito } \\
\text { firme }\end{array}$ & $\begin{array}{l}\text { Muito plást. I } \\
\text { muito peg. }\end{array}$ & Mod. e comum \\
\hline Bni2 & $207-285$ & 5YR $5 / 6$ & Forte gr. prism. & $\begin{array}{l}\text { Muito } \\
\text { dura }\end{array}$ & $\begin{array}{l}\text { Muito } \\
\text { firme }\end{array}$ & $\begin{array}{l}\text { Muito plást. / } \\
\text { muito peg. }\end{array}$ & Mod e comum \\
\hline Bni3 & $285-300+$ & $7,5 Y R 5 / 8$ & Mod. méd. Prism. & $\begin{array}{l}\text { Muito } \\
\text { dura }\end{array}$ & $\begin{array}{l}\text { Muito } \\
\text { firme }\end{array}$ & $\begin{array}{l}\text { Muito plást. } \\
\text { muito peg. }\end{array}$ & $\begin{array}{l}\text { Fracae } \\
\text { comum }\end{array}$ \\
\hline \multicolumn{8}{|c|}{ Perfil 2 - Cambissolo Háplico Alumínico típico } \\
\hline A & $0-11$ & 7,5 YR $3 / 4$ & Fraca peq. grumosa & $\begin{array}{l}\text { Lig. } \\
\text { Dura }\end{array}$ & $\begin{array}{l}\text { Muito } \\
\text { friável }\end{array}$ & $\begin{array}{l}\text { Năo plást. I } \\
\text { näo peg. }\end{array}$ & m \\
\hline $\mathrm{BA}$ & $11-20$ & 10YR 5/6 & $\begin{array}{l}\text { Fraca méd. bl. subang. I } \\
\text { forte muito peq. microag. }\end{array}$ & $\begin{array}{l}\text { Lig. } \\
\text { Dura }\end{array}$ & & $\begin{array}{l}\text { Lig plast. / lig. } \\
\text { peg. }\end{array}$ & - \\
\hline Bi1 & $20-85$ & GYR $5 / 7$ & $\begin{array}{l}\text { Fraca méd. bl. sub. I } \\
\text { forte muito peq. microag. }\end{array}$ & $\begin{array}{l}\text { Muito } \\
\text { dura }\end{array}$ & $\begin{array}{l}\text { Muito } \\
\text { friável }\end{array}$ & $\begin{array}{l}\text { Não plást. / lig. } \\
\text { peg. }\end{array}$ & - \\
\hline $\mathrm{Bi} 2$ & $85-113$ & 1OYR $5 / 6$ & $\begin{array}{l}\text { Mod. méd, bl. sub. / forte } \\
\text { muito peq. microag. }\end{array}$ & $\begin{array}{l}\text { Muito } \\
\text { dura }\end{array}$ & Firme & $\begin{array}{l}\text { Lig. plást. / } \\
\text { não peg. }\end{array}$ & - \\
\hline $\mathrm{BC}$ & $113-138$ & 10YR 5/6 & $\begin{array}{l}\text { Fraca maciça a traca } \\
\text { méd. bl. sub. }\end{array}$ & $\begin{array}{l}\text { Muito } \\
\text { dura }\end{array}$ & $\begin{array}{l}\text { Muito } \\
\text { friável }\end{array}$ & $\begin{array}{l}\text { Lig. plást. I } \\
\text { näo peg. }\end{array}$ & - \\
\hline C & $138 \sim 200$ & $2,5 Y R 5 / 4$ & Fraca maciça & Macia & $\begin{array}{l}\text { Muito } \\
\text { friável }\end{array}$ & $\begin{array}{l}\text { Não plást. I } \\
\text { não peg. }\end{array}$ & - \\
\hline
\end{tabular}

(1) peq. = pequena, méd.=média, $g r .=g r a n d e, ~ b l .=b l o c o s$, subang.=subangulares, microag $=$ microagregado, prism $=$ prismática, mod. $=$ moderada .

(2) lig.=ligeiramente, plást =plástica, peg. =pegajosa.

(3) Mod.=moderada

A porosidade no horizonte $\mathrm{BC}$ é tubular entre agregados. A partir de 200 $\mathrm{cm}$ apresenta porosidade fissural no interior de pequenos blocos de quartzo que se quebram com as mãos. A transição é abrupta linear.

Este horizonte C é uma isoalterita, pois a estrutura da rocha é perfeitamente conservada e se fratura preferencialmente seguindo a orientação do material. Apresenta coesão fraca e porosidade intersticial. 


\section{Perfil 6}

A porosidade do horizonte $\mathrm{A}$ é tubular, e está relacionada à atividade biológica. Este horizonte é extremamente rico em raízes e a transição é abrupta.

No horizonte BA a porosidade é tubular e abundante entre microagregado. Nota-se numerosos pedotúbulos preenchidos com material mais escuro. Há fragmentos de mica em abundância e a transição é gradual.

O horizonte Bw possui porosidade tubular entre microagregado forte. Nota-se a ocorrência de muitas raizes, particularmente abaixo dos blocos de migmatitos, alguns alterados. A presença desses blocos de rocha aliada a declividade deste trecho da vertente indica a ocorrência de coluvionamento. Fragmentos de mica são abundantes.

\section{Perfil 13}

O horizonte A possui porosidade e raizes em abundância. Ocorrência de grãos de quartzo milimétricos e de fragmentos de mica. A transição é gradual.

No horizonte BA a estrutura é em blocos subangulares e a subestrutura é microagregada e, em alguns trechos, grumosa. Porosidade tubular fina abundante e presença de pequenos pedotúbulos preenchidos por material de cor 10YR 3/6. Ocorrência de fragmentos de quartzo de $5 \mathrm{~mm}$ e de mica. A transição é clara.

A porosidade no horizonte Bw1 é tubular fina abundante entre microagregados. Nota-se inúmeros pedotúbulos de origem biológica e aumento de umidade em relação ao horizonte precedente. A presença de raizes grossas diminui e as raízes finas e médias permanecem numerosas. Presença de grãos de quartzo milimétricos e de mica. A transição é gradual.

No horizonte Bw2 a porosidade é tubular fina, numerosa entre microagregados. O solo torna-se mais seco e um pouco mais compacto do que 
no horizonte precedente. Presença de grãos de quartzo milimétricos ( 3 a 4 $\mathrm{mm}$ ), de fragmentos mica e de pontuações brancas (gibbsita). A transição é clara.

A porosidade no horizonte Bni1 é fissural entre agregados, com raras do tipo tubular fina. Nítida diminuição de raizes finas. Ocorrência de grãos de quartzo milimétricos a centimétricos, de fragmentos de muscovita e de pontuações brancas (gibbsita). Torna-se visivelmente mais seco e mais compacto que o horizonte anterior. A transição é gradual.

Neste horizonte de transição Bni1/Bni2 a porosidade é fissural entre agregados, com poucas do tipo tubular fina. Presença de grãos de quartzo milimétricos a centimétricos, de fragmentos de mica e de pontuações brancas (gibbsita).Torna-se ainda mais compacto. Rarissimas raízes finas. A transição é gradual.

A porosidade no horizonte Bni2 é fissural entre agregados, e a porosidade tubular fina torna-se ainda mais rara que no horizonte precedente. Nota-se fragmentos de rocha alterada, grãos de quartzo milimétricos a centimétricos, fragmentos de mica e pontuações brancas (provavelmente gibbsita ou caulinita). Ainda mais compacto do que o precedente.

\section{Perfil 4}

Nota-se, no horizonte $\mathbf{A}$, presença muitas raízes e porosidade tubular fina abundante.

O horizonte BA apresenta estrutura em blocos subangulares que se desfazem em microagregados e porosidade tubular fina abundante evidenciada nos estudos micromorfológicos (Figura 12a).

A figura 12b mostra a estrutura em blocos subangulares inferiores a $1 \mathrm{~cm}$ presentes no horizonte Bw1. Apresenta muitos pedotúbulos preenchidos com material mais escuro e porosidade tubular fina abundante. Presença, no topo do horizonte, de um bloco de rocha pouco intemperizada. Transição gradual. 
No horizonte Bw2 o grau de estruturação dos blocos subangulares torna-se moderado e a subestrutura mantém-se microagregada de grau forte. A presença de alguns blocos de rocha indica um possivel coluvionamento. Transição abrupta.

A estrutura no horizonte Bni1 torna-se prismática de grau moderado, com faces verticais oblíquas e alisadas (Figura 12c). Porosidade fissural entre agregados e diminuição da porosidade tubular. Torna-se nitidamente mais compacto e mais seco que o horizonte precedente. Transição gradual.

O horizonte Bni2 apresenta estrutura prismática de grau forte com faces verticais oblíquas e alisadas (Figura 12d), que possuem coloração um pouco mais amarelada do que no interior do agregado. Este horizonte é nitidamente mais compacto e mais seco do que o precedente. São raríssimas as raízes finas. Transição gradual.

A estrutura prismática, no horizonte Bni3, torna-se menos nítida e com faces verticais menos planas. A porosidade é tubular fraca. O solo volta a ficar mais úmido.

\section{Perfil 2}

A porosidade no horizonte A é abundante, sobretudo devido a presença de muitas raízes. A transição é clara.

No horizonte BA a porosidade é tubular bem desenvolvida. Apresenta fragmentos de mica e raízes finas e grossas em abundância. A transição é gradual.

O matiz do horizonte Bi1 é mais amarelado e a transição é gradual.

A porosidade tubular entre microagregados é bem desenvolvida no horizonte Bi2. Nota-se muita mica e algumas raizes. A transição é difusa.

No horizonte $\mathrm{BC}$ predomina a estrutura maciça com alguns blocos subangulares e a transição é clara. 
O horizonte $\mathrm{C}$ apresenta porosidade intersticial e tubular forte. Nota-se muitos fragmentos de mica e de blocos de rocha alterada.
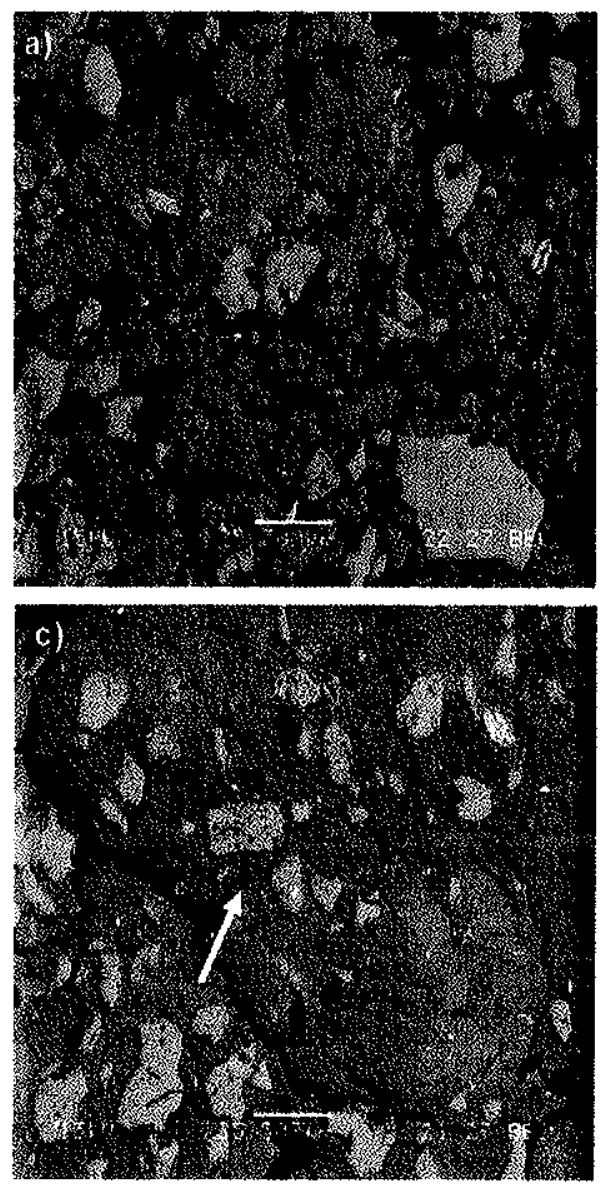
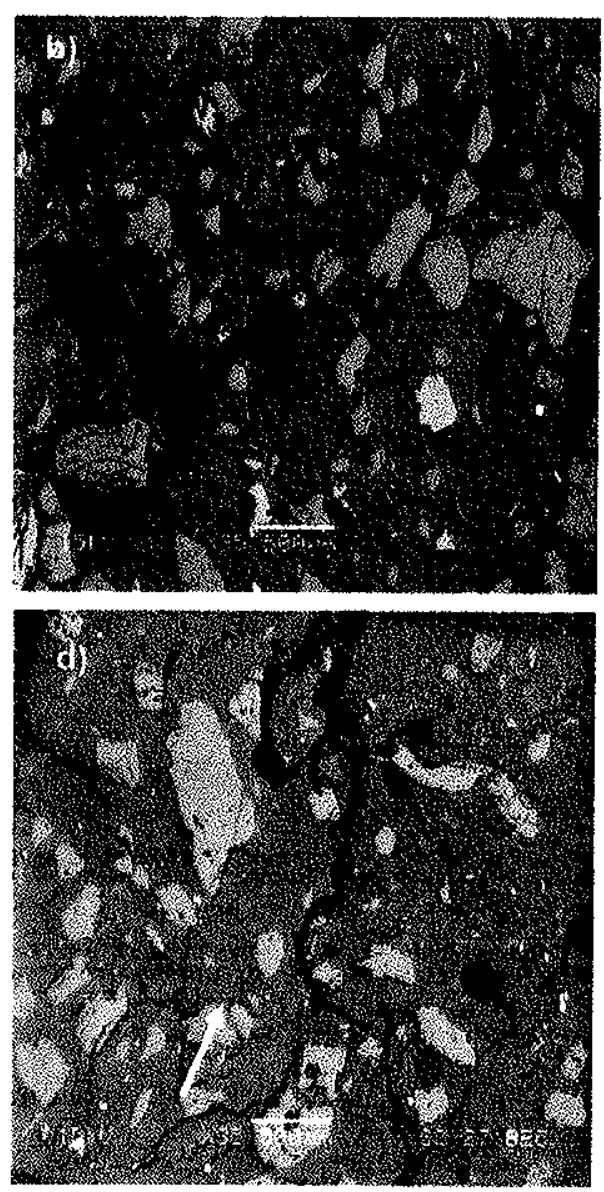

Figura 12 - Estas imagens obtidas por MEV mostram a evidente diminuição na porosidade (cor preta) entre os horizontes BA e BW1 (Figuras a e b) e as estruturas prismáticas, indicadas por seta, dos horizontes $\mathrm{Bn} 2$ e $\mathrm{Bn} 3$ (Figuras c e d) do perfil 4.

\subsubsection{Caracteristicas mineralógicas e físicas}

As análises por difração de raios- $X$ da fração argila deferrificada dos solos das trincheiras indicaram as seguintes fases: biotita, vermiculita com hidroxilas nos espaços interfoliares (VHE), interestratificados mica-vermiculita, caulinita e gibbsita, (Tabela 3). Esta assembléia mineralógica indica a coexistência de diferentes estágios de evolução do intemperismo, onde a mica (biotita e muscovita) pode se alterar em um conjunto de minerais de 
composições variadas, tipo VHE e interestratificados mica-VHE e caulinita ou em muscovita e sericita (Toledo-Groke, 1986; Buol \& Weed, 1991; Kretzschmar et al., 1997). Estes diferentes estágios de alteração dos minerais também indicam uma correlação entre o desenvolvimento da pedogênese $e$ os movimentos de massa (Furian et al., 1999).

A diminuição progressiva da intensidade dos picos diagnósticos (Figura 12) da VHE nos horizontes em direção à base dos perfis indica que possivelmente este argilomineral originou-se da alteração da mica (Vidal Torrado \& Lepsch, 1999; Vidal - Torrado et al., 1999). Os elevados valores de CTC (Tabelas 5 e 6) nos horizontes superficiais são atribuidos à participação do CT (Tabela 5 e 6) e ao acúmulo relativo de VHE. Nas condições atuais, a VHE nos horizontes superficiais teria maior estabilidade em relação a caulinita e por isso estaria contribuindo para o aumento da CTC (Karathanasis et al.,1983).

No perfil 5 (Latossolo Amarelo Distrófico típico) a presença de mica nos horizontes $\mathrm{BC}$ e $\mathrm{C}$, e de VHE e/ou de interestratificados mica-vermiculita nos horizontes superiores (Tabela 3) sugere que a mica está se transformando em caulinita, com formação daqueles como um estágio intermediário do intemperismo (Kretzschmar et al., 1997). O aumento do teor de caulinita (Tabela 3) em direção ao topo do perfil é um fator que corrobora com esta hipótese.

A assembléia mineralógica presente nos perfis 13 e 4 mostra que 0 material é qualitativamente homogêneo. No entanto, quantitativamente há um aumento progressivo de caulinita em direção à base dos perfis (Tabela 3), sendo observada uma menor porosidade total (Figura 20), e como conseqüência, menor permeabilidade (Ferreira et al., 1999). O aumento no teor de argila nos horizontes prismáticos dos perfis 13 e 4 , mostrado na tabela 4, não pode ser caracterizado como uma evidência de descontinuidade litológica (Recio Espejo et al., 2002). 


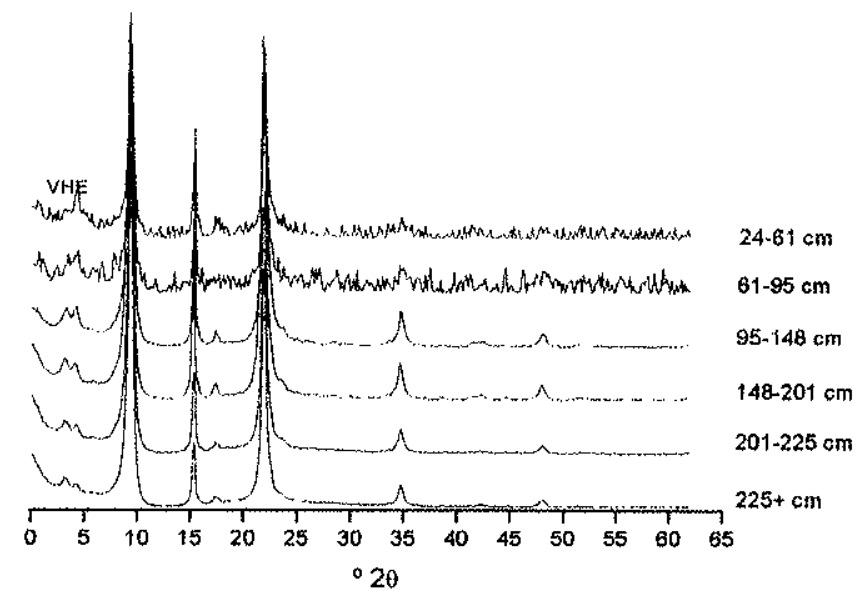

Figura 13 - Difratograma da fração argila natural deferrificada do perfil 13 mostrando a diminuição da VHE.

\subsubsection{Caracteristicas químicas}

Todos os perfis de solo estudados apresentam características químicas inerentes a solos tropicais sob vegetação de floresta (Tabela 5 e 6), sobretudo, quanto à disponibilidade de nutrientes limitada a serapilheira (Cecon, 2003).

Os perfis estudados apresentaram alta acidez ativa, potencial e trocável. Os valores de acidez potencial e trocável, normalmente são maiores nas camadas superficiais. Estes valores se devem, principalmente a presença do Al trocável nestas camadas, que também pode estar relacionado aos menores valores de $\mathrm{pH}$, principalmente, de $\mathrm{pH}$ em solução $\mathrm{CaCl} 2$ 0,01 mol L-1. Segundo Lindsay (1979), a diminuição de uma unidade de pH ocasiona aumento na atividade de $A l+3$ na solução em 42 ou 1000 vezes, dependendo se $0 A l+3$ encontrar-se em equilibrio com $\mathrm{Al}(\mathrm{OH}) 3$ amorfo ou óxidos e hidróxidos de $\mathrm{Al}$, respectivamente. Dada a presença "abundante" de gibbsita nos perfis estudados (Tabela 3), este comportamento inverso entre $\mathrm{pH}$ e disponibilidade de Al é perfeitamente normal. Os altos teores de matéria orgânica do solo, sobretudo dos horizontes superficiais, provavelmente são responsáveis pelos valores mais baixos da acidez trocável em comparação aos demais horizontes. 
Os ligantes orgânicos oriundos da degradação da MOS (matéria orgânica do solo) apresentam capacidade de formar complexos com cátions polivalentes, amenizando a toxidez de elementos como $\mathrm{Al}$ e $\mathrm{Mn}$, dentre outros metais pesados (Miyasawa et al., 1993)

A elevada acidez potencial dos perfis estudados, principalmente dos horizontes superficiais, esta relacionada a capacidade da MOS em liberar grupos funcionais protonados que, se desprotonados, mediante aumento de $\mathrm{pH}$, promovem a geração de cargas elétricas negativas, aumentando a CTC do solo. Portanto, os compostos hemicelulose, celulose, lignina e cera, que são abundantes na MOS de solos sob vegetação de floresta, promovem, com o passar dos anos e com ação microbiana, a formação de húmus (Stevenson, 1995).

Os baixos teores de $\mathrm{Ca}, \mathrm{Mg}, \mathrm{K}$ e Na nestes perfis de solo, bem como da baixa saturação por bases (V\%) encontram-se coerentes para solos sob vegetação de floresta. A sustentabilidade das florestas tropicais nativas esta relacionada a sua capacidade de ciclagem de nutrientes, associada a alta eficiência de uso dos elementos (Vitousek \& Sanford Jr, 1986). Com relação à ciclagem de nutrientes, a biogeoquímica tem sido a mais importante, por ser resultante das trocas químicas entre o solo e as plantas, com ênfase na importância da qualidade e quantidade da serapilheira (Poggiani \& Schumacher, 2000; Cecon, 2003). Esse fato explica a sustentabilidade de solos sob vegetação de floresta com baixíssimas concentrações de $\mathrm{Ca}, \mathrm{Mg}$ e $\mathrm{K}$ trocáveis, e alta saturação por alumínio (m\%).

As concentrações de $\mathrm{P}$ disponível foram decrescentes nos perfis. As maiores concentrações de $\mathrm{P}$ disponível nos horizontes superficiais esta relacionada ao efeito dos radicais orgânicos atuarem, nos ambientes ricos em MOS, como ânions competidores pelos sítios de adsorção de P. Assim, onde há maiores concentrações de MOS, e, conseqüentemente, radicais orgânicos, o P 
torna-se mais livre e, portanto, menores são os processos de adsorção deste nutriente (Novais \& Smith, 1999).

Os teores de $S$ não se mostraram limitantes nos perfis estudados. Provavelmente, mediante decomposição da liteira, os teores de $\mathrm{S}$ são mantidos em níveis satisfatórios. A ocorrência de maiores ou menores concentrações de S nos horizontes depende, acima de tudo, da competição dos sítios de adsorção de SO4-2 por ánions mais competitivos, como H2PO4- e ligantes orgânicos presentes na MOS (Raij, 1991).

Os teores de micronutrientes ( $\mathrm{B}, \mathrm{Cu}, \mathrm{Fe}, \mathrm{Mn}$ e $\mathrm{Zn}$ ) normalmente foram maiores nos horizontes superficiais, evidenciando novamente a atuação da MOS como fonte destes nutrientes no ecossistema. Quanto aos elementos traço $\mathrm{Cd}, \mathrm{Cr}, \mathrm{Ni}$ e $\mathrm{Pb}$, quando detectados pelo método empregado, apresentam-se em baixas concentrações.

Com relação a CTC, em todos os perfis estudados, maiores valores foram observados nos horizontes mais ricos em MOS, mostrando a dependência da troca catiônica pelos grupos funcionais da MOS. Estes dados corroboram com Raij (1969), que verificou que a MOS foi responsável por 56 a $91 \%$ e 6 a $86 \%$ da CTC de horizontes superficiais e subsuperficiais, respectivamente, nos solos do estado de São Paulo. Assim como nos latossolos estudados por Chauvel et al. (1983), foram observados menores valores de CTC nos horizontes prismáticos.

Portanto năo há duvida da importância da serapilheira, bem como da biomassa microbiana e das raízes, na retenção de nutrientes nos ecossistemas de florestas tropicais úmidas, sob solos altamente intemperizados e de baixa fertilidade natural (Vitousek \& Sanford Jr, 1986), como é o caso do presente estudo. 


\section{Tabela 3 - Características mineralógicas}

\begin{tabular}{|c|c|c|c|c|}
\hline \multirow{2}{*}{\multicolumn{2}{|c|}{$\begin{array}{c}\text { Horizonte Profundidade } \\
(\mathrm{cm})\end{array}$}} & \multirow{2}{*}{$\begin{array}{c}\text { Mineralogia }{ }^{(1),(2)} \\
\text { Fração Argila } \\
\end{array}$} & \multicolumn{2}{|c|}{ Teor $(\%)^{(3)}$} \\
\hline & & & & Caulinita \\
\hline \multicolumn{5}{|c|}{ Perfil 5 - Latossolo Amarelo Distrófico típico } \\
\hline A & $0-15$ & $C, G, M V$ & 30,27 & 66,54 \\
\hline $\mathrm{A} / \mathrm{BA}$ & $15-23$ & $C, G, V H E$ & 26,81 & 64,41 \\
\hline$B A$ & $27-35$ & C, G, VHE & 27,41 & 62,93 \\
\hline Bw1 & $65-73$ & $C, G, V H E$ & 33,95 & 61,79 \\
\hline Bw1 & $83-91$ & $C, G, V H E$ & 33,36 & 58,93 \\
\hline $\mathrm{Bw} 1 / \mathrm{Bw} 2$ & $103-116$ & $C, G, V H E$ & 35,90 & 55,77 \\
\hline Bw2 & $135-144$ & $C, G, V H E$ & 31,72 & 67,88 \\
\hline $\mathrm{BC}$ & $175-183$ & $\mathrm{C}, \mathrm{G}, \mathrm{VHE}, \mathrm{M}$ & 49,14 & 50,72 \\
\hline C & $210+$ & $C, G, M$ & 58,25 & - \\
\hline \multicolumn{5}{|c|}{ Perfil 6 - Latossolo Amarelo Distrófico cámbico } \\
\hline A & 0.26 & $C, G, M V$ & s.a. ${ }^{(4)}$ & s.a. \\
\hline $\mathrm{Bi1}$ & $26-55$ & $C, G, V H E, M, M V$ & s.a. & s.a. \\
\hline $\mathrm{Bi} 2$ & $55-160+$ & $C, G, V H E$ & s.a. & s.a. \\
\hline \multicolumn{5}{|c|}{ Perfil 13 - Latossolo Amarelo Distrófico argissólico } \\
\hline BA & $24-61$ & $C, G, V H E, M V$ & 20,16 & 63,73 \\
\hline Bw1 & $61-95$ & $C, G, V H E, M V$ & 16,27 & 68,05 \\
\hline Bw2 & $95-148$ & C, G, VHE, MV & 13,44 & 73,90 \\
\hline Bnit & 148-201 & $C, G, V H E, M V$ & 14,20 & 81,60 \\
\hline Bni1/Bni2 & $201-225$ & $C, G, V H E, M V$ & 13,37 & 79,05 \\
\hline Bni2 & $225+$ & $C, G, V H E, M V$ & 12,47 & 80,42 \\
\hline \multicolumn{5}{|c|}{ Perfil 4 - Latossolo Amarelo Distrófico argissólico } \\
\hline A & $0-11$ & $C, G, V H E$ & 33,77 & 64,39 \\
\hline $\mathrm{BA}$ & $11-27$ & $C, G, V H E, M V$ & 18,14 & 66,01 \\
\hline Bw1 & $27-60$ & $C, G, V H E, M V$ & 19,44 & 71,20 \\
\hline$B w 2$ & $60-100$ & C, G, VHE, MV & 17,21 & 73,50 \\
\hline Bni1 & $100-207$ & $C, G, V H E, M, M V$ & 15,44 & 75,47 \\
\hline Bni2 & $207-285$ & C, $G, V H E, M$ & 11,62 & 83,01 \\
\hline Bni3 & $285-300+$ & $C, G, V H E, M$ & 11,12 & 80,46 \\
\hline \multicolumn{5}{|c|}{ Perfil 2 - Cambissolo Háplico Alumínico típico } \\
\hline A & $0-11$ & $C, G, M V$ & 27,59 & 61,33 \\
\hline BA & $11-20$ & C, G, VHE, MV & 16,94 & 62,31 \\
\hline Bi1 & $20-85$ & $C, G, V H E, M V$ & 16,78 & 60,54 \\
\hline $\mathrm{Bi} 2$ & $85-113$ & $C, G, V H E, M V$ & 16,77 & 74,24 \\
\hline$B C$ & $113-138$ & $C, G, V H E, M V$ & 17,99 & 74,10 \\
\hline $\mathrm{C}$ & $138-200$ & $\mathrm{C}, \mathrm{G}, \mathrm{M}, \mathrm{MV}$ & s.a. & s.a. \\
\hline
\end{tabular}

(1) Determinada por difração de raios- $X$.

(2) $\mathrm{C}=$ caulinita, $\mathrm{G}=$ gibbsita, $\mathrm{VHE}=$ vermiculita com hidroxilas nos espaços interfoliares, $M=$ mica, $M V=$ interestratificado mica-vermiculita.

(3) Determinado por análise térmica diferencial e gravimétrica.

(4) s.a. = sem análise. 
Tabela 4 - Características físicas

\begin{tabular}{|c|c|c|c|c|c|c|c|c|}
\hline \multicolumn{2}{|c|}{ Horizonte Profundidade } & \multicolumn{2}{|c|}{ Areia ${ }^{(1)}$} & \multirow{2}{*}{$\begin{array}{l}\text { Areia total } \\
\quad \mathrm{G} \mathrm{kg}^{-1}\end{array}$} & \multirow[t]{2}{*}{ Silte } & \multirow[t]{2}{*}{ Argila } & \multirow{2}{*}{$\begin{array}{c}\text { Densidade } \\
\mathrm{g} \mathrm{cm}^{-3}\end{array}$} & \multirow[t]{2}{*}{ Classe textural } \\
\hline & $\mathrm{Cm}$ & G & $\mathrm{F}$ & & & & & \\
\hline \multicolumn{9}{|c|}{ Perfil 5 - Latossolo Amarelo Distrófico típico } \\
\hline A & $0-15$ & 375,31 & 156,84 & 532,15 & 170,27 & 297,58 & 0,99 & Franco-argilo-arenosa \\
\hline $\mathrm{BA}$ & $15-46$ & 351,44 & 166,81 & 518,25 & 121,01 & 360,74 & 1,03 & Argilo-arenosa \\
\hline$B w 1$ & $46-103$ & 331,85 & 167,67 & 499,51 & 155,33 & 345,16 & 1,31 & Franco-argilo-arenosa \\
\hline Bw2 & $103-160$ & 260,56 & 138,32 & 398,89 & 317,79 & 283,32 & 1,45 & Franco-argilosa \\
\hline $\mathrm{BC}$ & $160-210$ & 300,13 & 91,98 & 392,11 & 349,15 & 258,74 & 1,57 & Franca \\
\hline $\mathrm{C}$ & $210-240$ & 390,70 & 90,05 & 480,80 & 301,89 & 217,36 & 1,39 & Franca \\
\hline \multicolumn{9}{|c|}{ Perfil 6 - Latossolo Amarelo Distrófico câmbico } \\
\hline A & $0-26$ & 299,54 & 229,50 & 529,00 & 149,85 & 321,11 & 0,89 & Franco-argilo-arenosa \\
\hline BA & $26-55$ & 322,59 & 213,37 & 535,96 & 164,95 & 299,09 & 1,11 & Franco-argilo-arenosa \\
\hline Bw & $55-160$ & 282,00 & 275,90 & 557,90 & 191,07 & 251,04 & 1,03 & Franco-argilo-arenosa \\
\hline \multicolumn{9}{|c|}{ Perfil 13 - Latossolo Amarelo Distrofico argissólico } \\
\hline $\mathrm{BA}$ & $24-61$ & 292,59 & 201,41 & 494,00 & 169,50 & 336,50 & 1,2 & Franco-argilo-arenosa \\
\hline Bw1 & $61-95$ & 258,00 & 195,28 & 453,27 & 192,57 & 354,15 & 1,24 & Argilo-arenosa \\
\hline Bw2 & $95-148$ & 261,46 & 188,63 & 450,09 & 173,07 & 376,84 & 1,38 & Argilo-arenosa \\
\hline Bni1 & $148-201$ & 259,46 & 201,14 & 460,60 & 177,88 & 361,52 & 1,46 & Argilo-arenosa \\
\hline Bni1/Bni2 & $201-225$ & 237,20 & 187,09 & 424,28 & 141,45 & 434,26 & 1,43 & Argilosa \\
\hline Bni2 & $225+$ & 253,93 & 141,20 & 395,13 & 176,98 & 427,89 & 1,41 & Argilosa \\
\hline \multicolumn{9}{|c|}{ Perfil 4 - Latossolo Amarelo Distrófico argissólico } \\
\hline A & 0.11 & 380,00 & 200,00 & 580,00 & 90,00 & 330,00 & 0,94 & Franco-argilo-arenosa \\
\hline BA & $11-27$ & 352,62 & 165,09 & 517,71 & 158,26 & 324,02 & 1,19 & Franco-argilo-arenosa \\
\hline Bw1 & $27-60$ & 351,73 & 161,83 & 513,57 & 153,36 & 333,07 & 1,26 & Franco-argilo-arenosa \\
\hline Bw2 & $60-100$ & 292,79 & 186,25 & 479,04 & 144,24 & 376,72 & 1,26 & Argilo-arenosa \\
\hline Bni1 & $100-207$ & 264,46 & 170,35 & 434,81 & 194,80 & 370,39 & 1,41 & Franco-argilosa \\
\hline Bni2 & $207-285$ & 195,78 & 149,53 & 345,31 & 240,31 & 414,38 & 1,36 & Argilosa \\
\hline Bni3 & $285-300+$ & 236,36 & 158,86 & 395,21 & 140,17 & 464,61 & 1,32 & Argilosa \\
\hline \multicolumn{9}{|c|}{ Perfil 2 - Cambissolo Háplico Alumínico típico } \\
\hline A & $0-11$ & 406,15 & 139,01 & 545,20 & 194,70 & 260,10 & 0,86 & Franco-argilo-arenosa \\
\hline $\mathrm{BA}$ & $11-20$ & 372,75 & 173,82 & 546,60 & 174,00 & 279,40 & 1,01 & Franco-argilo-arenosa \\
\hline $\mathrm{Bi1}$ & $20-85$ & 366,27 & 174,51 & 540,70 & 141,90 & 317,40 & 1,08 & Franco-argilo-arenosa \\
\hline $\mathrm{Bi} 2$ & $85-113$ & 331,52 & 194,96 & 526,50 & 152,10 & 321,40 & 1,24 & Franco-argilo-arenosa \\
\hline $\mathrm{BC}$ & $113-138$ & 327,15 & 220,68 & 547,80 & 227,80 & 224,40 & 1,36 & Franco-argilo-arenosa \\
\hline $\mathrm{C}$ & $138-200$ & 374,30 & 253,68 & 628,00 & 154,90 & 217,10 & 1,4 & Franco-argilo-arenosa \\
\hline
\end{tabular}


Tabela 5 - Resultado das análises químicas dos perfis 5 (Latossolo Amarelo Distrófico típico), 6 (Latossolo Amarelo Distrófico câmbico) e 13 (Latossolo Amarelo Distrófico argissólico)

\begin{tabular}{|c|c|c|c|c|c|c|c|c|c|c|c|c|c|c|c|}
\hline \multirow[t]{2}{*}{$\mathrm{Hz}$} & Prof. & \multicolumn{3}{|c|}{$\mathrm{pH}$} & \multirow{2}{*}{$\begin{array}{l}\mathrm{M} \cdot \mathrm{O}_{-} \\
\mathrm{g} \mathrm{kg}\end{array}$} & \multirow[t]{2}{*}{$\mathrm{H}+\mathrm{Al}$} & \multirow[t]{2}{*}{$\mathrm{Al}$} & \multirow[t]{2}{*}{$\mathrm{Ca}$} & \multirow{2}{*}{$\begin{array}{c}\mathrm{Mg} \\
\mathrm{mmol}_{\mathrm{c}} \mathrm{kg} \\
-\end{array}$} & \multirow{2}{*}{-1} & \multirow[t]{2}{*}{$\mathrm{Na}$} & \multirow[t]{2}{*}{ SB } & \multirow[t]{2}{*}{ CTC } & \multirow{2}{*}{$\begin{array}{l}M \\
\% \\
\end{array}$} & \multirow{2}{*}{$\begin{array}{l}\mathrm{V} \\
\%\end{array}$} \\
\hline & $\mathrm{Cm}$ & $\mathrm{H}_{2} \mathrm{O}$ & $\mathrm{KCl}$ & $\mathrm{CaCl}_{2}$ & & & & & & & & & & & \\
\hline \multicolumn{16}{|c|}{ Perfil 5 - Latossolo Amarelo Distrófico típico } \\
\hline A & $0-10$ & 4,02 & 3,45 & 3,55 & 62 & 126,1 & 33,7 & $<L^{(1)}$ & 1,36 & 1,14 & 0,63 & 3,13 & 129,23 & 91,5 & 2,42 \\
\hline BA & $15-23$ & 4,45 & 4,12 & 3,99 & 59 & 90,8 & 20,3 & $<L D$ & 1,27 & 0,65 & 0,54 & 2,46 & 93,26 & 89,19 & 2,64 \\
\hline Bw1 & $65-73$ & 4,42 & 4,31 & 4,12 & 43 & 35,7 & 40,5 & $\angle L D$ & 0,54 & 0,06 & $<\mathrm{LD}^{(4)}$ & 0,6 & 36,3 & 94,59 & 1,66 \\
\hline $\mathrm{Bw} 2$ & $136-144$ & 4,58 & 4,31 & 4,14 & 6 & 16,2 & 7,1 & $<\mathrm{LD}$ & 0,36 & $<\mathrm{LD}^{(3)}$ & $<L D$ & 0,36 & 16,56 & 95,17 & 2,19 \\
\hline $\mathrm{BC}$ & $175-183$ & 4,83 & 4,59 & 4,33 & 5 & 12,3 & 2,4 & $<\mathrm{LD}$ & 0,36 & 0,04 & $<L D$ & 0,4 & 12,7 & 85,71 & 3,13 \\
\hline \multicolumn{16}{|c|}{ Perfil 6 - Latossolo Amarelo Distrófico câmbico } \\
\hline A & $0-10$ & 3,73 & 3,28 & 3,42 & 58 & 137 & 39,2 & $<L D$ & 3,44 & 1,22 & 1,47 & 6,13 & 143,13 & 86,48 & 4,28 \\
\hline $\mathrm{BA}$ & $49-57$ & 4,15 & 3,97 & 4,02 & 51 & 150,4 & 23,2 & $<\mathrm{LD}$ & 1,09 & 0,27 & 0,54 & 1,9 & 152,3 & 92,43 & 1,25 \\
\hline Bw1 & $90-98$ & 4,27 & 4,04 & 4,09 & 45 & 256,2 & 18,9 & $<L D$ & 1,09 & 0,4 & 0,76 & 2,25 & 258,45 & 89,36 & 0,87 \\
\hline \multicolumn{16}{|c|}{ Perfil 13 - Latossolo Amarelo Distrófico argissólico } \\
\hline A & $0-24$ & s.a. ${ }^{(5)}$ & s.a. & s.a. & s.a. & s.a. & s.a. & s.a. & s.a. & s.a. & s.a. & s.a. & s.a. & s.a. & s.a. \\
\hline BA & $24-61$ & 4,68 & 4,22 & 4,1 & 53 & 58,17 & 17,7 & $<L D$ & 0,27 & 0,27 & $<L D$ & 0,54 & 58,71 & 97,04 & 0,93 \\
\hline Bw1 & $61-95$ & 4,65 & 4,26 & 4,16 & 49 & 43,47 & 14,8 & $<L D$ & 0 & 0,12 & $\angle L D$ & 0,12 & 43,58 & 99,2 & 0,27 \\
\hline Bw2 & $95-148$ & 4,81 & 4,2 & 4,14 & 45 & 35,97 & 15,4 & $<L D$ & 0 & 0,09 & $<L D$ & 0,09 & 36,06 & 99,42 & 0,26 \\
\hline Bnit & $148-201$ & 4,85 & 4,27 & 4,17 & 7 & 28,17 & 10,7 & $<L D$ & $<\mathrm{LD}^{(2)}$ & 0,07 & $<L D$ & 0,07 & 28,23 & 99,35 & 0,24 \\
\hline Bni1/Bni2 & $201-225$ & 4,88 & 4,31 & 4,19 & 5 & 27,37 & 8,6 & $<L D$ & $<L D$ & 0,07 & $<L D$ & 0,07 & 27,43 & 99,19 & 0,24 \\
\hline Bni2 & $225+$ & 4,85 & 4,28 & 4,12 & 5 & 26,77 & 9,1 & $<L D$ & $<\mathrm{LD}$ & 0,04 & $<L D$ & 0,04 & 26,81 & 99,56 & 0,15 \\
\hline
\end{tabular}


Tabela 5 - Resultado das análises químicas dos perfis 5 (Latossolo Amarelo Distrófico típico), 6 (Latossolo Amarelo Distrófico câmbico) e 13 (Latossolo Amarelo Distrófico argissólico)

\begin{tabular}{|c|c|c|c|c|c|c|c|c|c|c|c|c|}
\hline $\mathrm{Hz}$ & $\begin{array}{c}\text { Prof. } \\
\mathrm{cm}\end{array}$ & $\mathbf{P}$ & $\mathrm{S}$ & $\mathbf{B}$ & $\mathrm{Cu}$ & $\mathrm{Fe}$ & $\begin{array}{c}\mathrm{Mn} \\
\mathrm{kg}^{-3}\end{array}$ & $\mathrm{Zn}$ & Cd & $\mathrm{Cr}$ & $\mathrm{Ni}$ & $\mathrm{Pb}$ \\
\hline \multicolumn{13}{|c|}{ Perfil 5 - Latossolo Amarelo Distrófico típico } \\
\hline A & 0.10 & 18,75 & 15,5 & 1,44 & 0,67 & 257,49 & 1,64 & 0,94 & $<\mathrm{LD}^{(7)}$ & 0,09 & $<\mathrm{LD}^{(9)}$ & 0,91 \\
\hline $\mathrm{BA}$ & $15-23$ & 7,1 & 13,56 & 0,92 & 0,37 & 63,35 & 0,78 & 0,29 & $<\mathrm{LD}$ & 0,06 & $<\mathrm{LD}$ & 0,43 \\
\hline Bw1 & $65-73$ & 2,3 & 28,55 & 0,21 & 0,43 & 34,06 & 0,52 & 0,41 & $<\mathrm{LD}$ & 2,03 & $<L D$ & 0,37 \\
\hline Bw2 & $136-144$ & 0,24 & 9,82 & $<\mathrm{LD}^{(6)}$ & 0,37 & 3,57 & 0,07 & 0,2 & $<L D$ & 0,03 & $<L D$ & 0,37 \\
\hline $\mathrm{BC}$ & $175-183$ & 2,7 & 13,05 & $<L D$ & 0,36 & 6,58 & 0,75 & 0,23 & $\angle L D$ & 0,25 & $\angle L D$ & 0,5 \\
\hline \multicolumn{13}{|c|}{ Perfil 6 - Latossolo Amarelo Distrófico câmbico } \\
\hline A & $0-10$ & 18,28 & 21,44 & 3,11 & 1,2 & 374,79 & 3,35 & 2,41 & $<L D$ & 0,17 & $<L D$ & 1,71 \\
\hline $\mathrm{BA}$ & $49-57$ & 7,1 & 48,7 & 0,27 & 0,88 & 58,39 & 4,23 & 0,39 & $<L D$ & 0,04 & $<L D$ & 0,74 \\
\hline Bw1 & $90-98$ & 6,5 & 53,87 & 0,25 & 1,02 & 49,09 & 4,12 & 0,26 & $<L D$ & $<\operatorname{LD}^{(8)}$ & $<L D$ & 0,87 \\
\hline \multicolumn{13}{|c|}{ Perfil 13 - Latossolo Amarelo Distrófico argissólico } \\
\hline A & 0.24 & s.a. & s.a. & s.a. & s.a. & s.a. & s.a. & s.a. & s.a. & s.a. & s.a. & s.a. \\
\hline $\mathrm{BA}$ & $24-61$ & 0,84 & 64,07 & 0,21 & 0,67 & 76,85 & 0,57 & 0,22 & $<\mathrm{LD}$ & 0,07 & $<L D$ & 1,06 \\
\hline Bw1 & $61-95$ & 0,91 & 66,4 & 0,14 & 0,39 & 43,35 & 0,25 & 0,13 & $<L D$ & 0,05 & $<L D$ & 0,58 \\
\hline$B w 2$ & $95-148$ & 0,57 & 29,32 & 0,1 & 0,19 & 18,89 & 0,13 & 0,18 & $<L D$ & $<L D$ & $<L D$ & 0,42 \\
\hline Bni1 & $148-201$ & 0,44 & 55,68 & 0,18 & 0,13 & 6,85 & 0,04 & 0,16 & $<L D$ & $<L D$ & $<L D$ & 0,41 \\
\hline Bni1/Bni2 & $201-225$ & 0,37 & 80,48 & 0,11 & 0,11 & 5,12 & 0,04 & 0,16 & $<L D$ & $<L D$ & $\angle L D$ & 0,24 \\
\hline Bni2 & $225+$ & 0,17 & 91,98 & 0 & 0,11 & 6,13 & 0,03 & 0,2 & $<L D$ & $<L D$ & $\angle L D$ & 0,16 \\
\hline
\end{tabular}
(1) $\mathrm{LD}=$ limite de detecção para $\mathrm{Ca}=0.25$ mmolc $\mathrm{kg}-1$
(2) $\mathrm{LD}=$ limite de detecçäo para $\mathrm{Mg}=0.10$ mmolc $\mathrm{kg}-1$
(3) $\mathrm{LD}=$ limite de deteção para $\mathrm{K}=0.02 \mathrm{mmolc} \mathrm{kg}-1$
(4) $\mathrm{LD}=$ limite de detecção para $\mathrm{Na}=0.01 \mathrm{mmolc} \mathrm{kg}-1$
(5) s.a. = sem análise.
(6) $\mathrm{LD}=$ limite de detecção para $\mathrm{B}=0.015 \mathrm{mg} \mathrm{kg-1}$
(7) $\mathrm{LD}=$ limite de deteccaso para $\mathrm{Cd}=0.014 \mathrm{mg} \mathrm{kg}-1$
(8) $\mathrm{LD}=$ limite de deteç̧ão para $\mathrm{Cr}=0.012 \mathrm{mg} \mathrm{kg}-1$
(9) $\mathrm{LD}=$ limite de detecção para $\mathrm{Ni}=0.046 \mathrm{mg} \mathrm{kg}-1$ 
Tabela 6 - Resultado das análises químicas dos perfis 4 (Latossolo Amarelo Distrófico argissólico) e 2 (Cambissolo Háplico Alumínico típico)

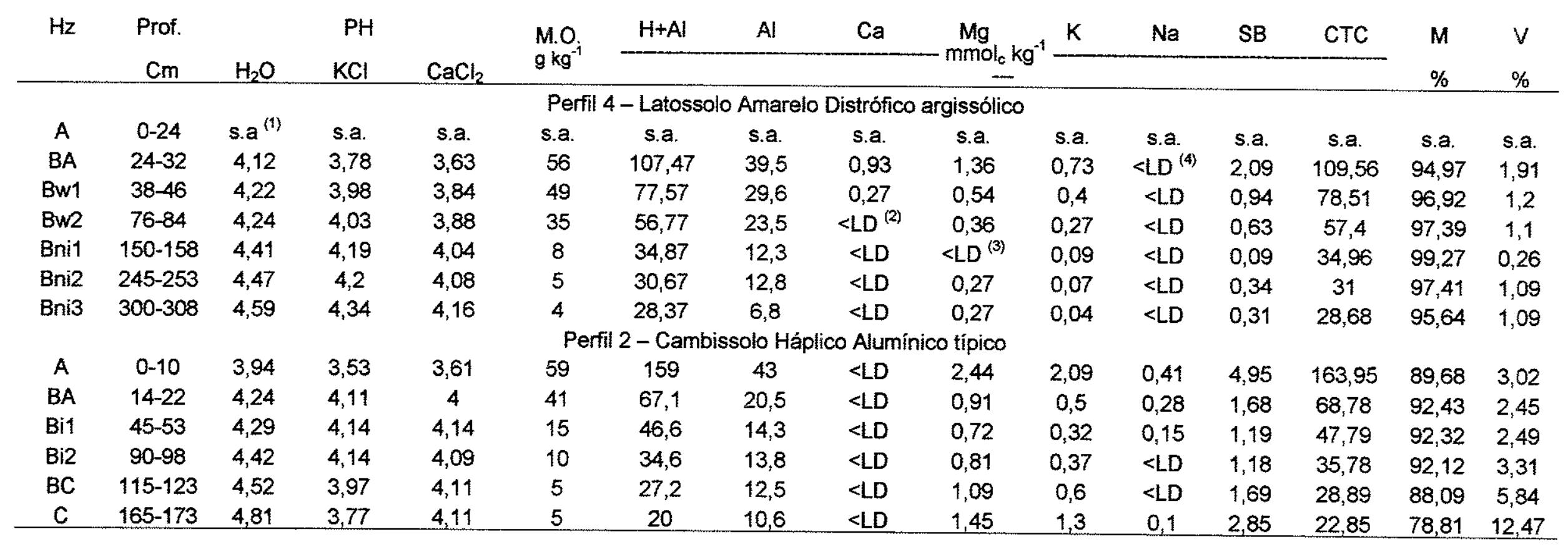


Tabela 6 - Resultado das análises químicas dos perfis 4 (Latossolo Amarelo Distrófico argissólico) e 2 (Cambissolo Háplico Alumínico típico).

\begin{tabular}{|c|c|c|c|c|c|c|c|c|c|c|c|c|}
\hline $\mathrm{Hz}$ & $\begin{array}{c}\text { Prof. } \\
\mathrm{cm}\end{array}$ & $P$ & $S$ & $B$ & $\mathrm{Cu}$ & $\mathrm{Fe}$ & $\begin{array}{r}\mathrm{Mn} \\
\mathrm{kg}^{-1}\end{array}$ & $\mathrm{Zn}$ & $\mathrm{Cd}$ & $\mathrm{Cr}$ & $\mathrm{Ni}$ & $\mathrm{Pb}$ \\
\hline \multicolumn{13}{|c|}{ Perfil 4 - Latossolo Amarelo Distrófico argissólico } \\
\hline A & $0-24$ & s.a. & s.a. & s.a. & s.a. & s.a. & s.a. & s.a. & s.a. & s.a. & s.a. & s.a. \\
\hline$B A$ & $24-32$ & 4,63 & 59,04 & 0,98 & 0,85 & 272,21 & 1,83 & 0,47 & $<L D^{(6)}$ & 0,2 & $<\mathrm{LD}^{(8)}$ & 1,67 \\
\hline Bw1 & $38-46$ & 3,04 & 72,08 & 0,54 & 0,78 & 127,22 & 3,12 & 0,29 & $<L D$ & 0,12 & $<L D$ & 1,35 \\
\hline Bw2 & $76-84$ & 1,84 & 64,85 & 0,29 & 0,41 & 50,48 & 2,32 & 0,22 & $\angle L D$ & 0,06 & $<L D$ & 0,84 \\
\hline Bni1 & $150-158$ & 0,31 & 69,63 & 0,05 & 0,1 & 5,91 & 0,06 & 0,14 & $<L D$ & 0,05 & $\angle L D$ & 0,51 \\
\hline Bni2 & $245-253$ & 0,51 & 97,4 & 0,1 & 0,1 & 3,68 & 0,05 & 0,14 & $<L D$ & $<L D^{(n)}$ & $<L D$ & 0,57 \\
\hline Bni3 & $300-308$ & 0,84 & 134,73 & 0,09 & 0,08 & 3,4 & 0,04 & 0,15 & $<\mathrm{LD}$ & $<L D$ & $<L D$ & 0,53 \\
\hline \multicolumn{13}{|c|}{ Perfil 2 - Cambissolo Háplico Alumínico típico } \\
\hline A & $0-10$ & 19,48 & 12,66 & 1,59 & 0,68 & 299,53 & 4,91 & 1,05 & $<L D$ & 0,29 & $<L D$ & 1,03 \\
\hline $\mathrm{BA}$ & $14-22$ & 1,97 & 18,34 & 0,37 & 0,39 & 63,31 & 3,68 & 0,29 & $<L D$ & $<L D$ & $<L D$ & 0,5 \\
\hline $\mathrm{Bi1}$ & $45-53$ & 1,77 & 9,04 & 0,16 & 0,31 & 43,54 & 2,82 & 0,19 & $<L D$ & $<L D$ & $<L D$ & 0,45 \\
\hline $\mathrm{Bi} 2$ & $90-98$ & 0,64 & 8,66 & 0,08 & 0,27 & 22,65 & 1,31 & 0,16 & $<\mathrm{LD}$ & $<L D$ & $<L D$ & 0,35 \\
\hline$B C$ & $115-123$ & 0,71 & 5,68 & $<\mathrm{LD}^{(5)}$ & 0,39 & 12,58 & 1,51 & 0,18 & $<L D$ & $\angle L D$ & $<L D$ & 0,48 \\
\hline C & $165-173$ & 16,42 & 5,55 & $\angle L D$ & 0,5 & 10,57 & 2,79 & 0,31 & $\angle L D$ & $\angle L D$ & $\angle L D$ & 0,44 \\
\hline
\end{tabular}
(1) $s . a .=$ sem análise.
(2) $\mathrm{LD}=$ limite de deteç̧ão para $\mathrm{Ca}=0.25 \mathrm{mmolc} \mathrm{kg}-1$
(3) $\mathrm{LD}=$ limite de detecção para $\mathrm{Mg}=0.10 \mathrm{mmolc} \mathrm{kg}-1$
(4) $\mathrm{LD}=$ limite de deteç̧ão para $\mathrm{Na}=0.01 \mathrm{mmolc} \mathrm{kg}-1$
(5) $\mathrm{LD}=$ limite de detecção para $\mathrm{B}=0.015 \mathrm{mg} \mathrm{kg}-1$
(6) $\mathrm{LD}=$ limite de deteçãa para $\mathrm{Cd}=0.014 \mathrm{mg} \mathrm{kg}-1$
(7) $\mathrm{LD}=$ limite de deteç̧ầo para $\mathrm{Cr}=0.012 \mathrm{mg} \mathrm{kg}-1$ 


\subsection{Conclusão}

Os perfis de solo da vertente estudada foram classificados como Latossolo Amarelo Distrófico típico (perfil 5), Latossolo Amarelo Distrófico câmbico (perfil 6), Latossolo Amarelo Distrófico argissólico (perfil 13), Latossolo Amarelo Distrófico argissólico (perfil 4) e por Cambissolo Háplico Alumínico típico (perfil 2) (Embrapa, 1999).

Estes solos têm textura franco-argilo-arenosa e argilo-arenosa, com estrutura entre grumosa nos horizontes superficiais e em blocos subangulares com subestrutura microagregada nos demais horizontes. Os perfis 13 e 4 possuem horizontes prismáticos de textura argilosa com menor porosidade e maior densidade. Embora, o aumento relativo dos valores de densidade nos prismáticos tenha sido observado nestes dois perfis, tais valores coincidem com aqueles encontrados nos horizontes Bw no perfil 5 .

Os horizontes prismáticos possuem maiores teores de caulinita, que está relacionado com o aumento dos ciclos de contração e expansão, o que contribui para a diminuição da porosidade. As características químicas, destes solos sob vegetação de floresta, indicam que quanto à disponibilidade de nutrientes há dependência com a serapilheira.

Embora não tenham sido realizados ensaios físicos para determinar a dinâmica da água na toposseqüência, em observações de campo, ficou evidente que os horizontes prismáticos impedem a infiltração da água e promovem a formação de fluxo subsuperficial lateral. São estes fluxos laterais aliados à declividade das vertentes que promovem os processos erosivos. Contudo, é fundamental a realização das análises físicas para comprovar esta hipótese. 


\section{ESTUDOS MICROMORFOLÓGICOS DE SEQÜÊNCIA DE SOLOS EM MICROBACIA HIDROGRAFICA "B"}

\section{RESUMO}

A micromorfologia e a análise de imagem são ferramentas que podem ser utilizadas em estudos referentes à susceptibilidade do solo a perda de massa, na escala micrométrica, antes que esta tome dimensões irreversíveis ou de solução incompatível do ponto de vista econômico. No presente trabalho utilizamos estas técnicas para compreender o funcionamento de latossolos que possuem horizontes prismáticos em profundidade. E também procuramos evidências de solifluxão e de formação de aqüifero suspenso devido à compactação desses horizontes. Objetivou-se, neste trabalho, caracterizar micromorfologicamente os solos dos cinco perfis de uma toposseqüência localizada na microbacia "B" do Núcleo Cunha-Indaiá, no Parque Estadual da Serra do Mar - SP. E, principalmente, avaliar a diferença na distribuição da porosidade, nos parâmetros de tamanho e forma, entre os horizontes microagregados e os prismáticos de um Latossolo Amarelo Distrófico argissólico (perfil 4), através do uso da análise de imagem. Os resultados confirmaram a existência de diminuição e diferença na forma dos poros nos horizontes prismáticos quando comparados com os microagregados. No material analisado dos horizontes prismáticos não foram observadas feições de argiluviação, embora a análise granulométrica tenha indicado aumento na quantidade de argila nos horizontes em questão. As fábricas birrefringentes poroestriadas e granoestriadas presentes nestes horizontes indicam que o solo possui um alto potencial de contração e expansão. 
MICROMORPHOLOGICAL STUDIES IN SEQUENCE OF SOILS IN SMALL WATERSHED "B"

\section{ABSTRACT}

The micromorphology and the image analysis are tools that they could be used in studies about the erosion susceptibility at the micrometric scale, before this takes irreversible dimensions or incompatible to solve on the economical point of view. In the present work used these techniques to understand the dynamic of a Oxisols that has prismatic horizons in depth. Additionally, we looked for evidences of soil creeping and formation of suspended aquiferous due to the compactation of those horizons. The aim was characterized micromorphologically the soils of the five profiles of a toposequence located in the small watershed "B" of the "Núcleo Cunha-Indaiá" in the "Parque Estadual da Serra do Mar - SP". Besides, by the image analysis it was evaluated the difference in the porosity distribution, related to size and forms scale, between the oxic and the prismatic horizons of a Oxisol (profile 4). The results confirmed the decrease and the difference of the pore form distribution in the prismatic horizons when compared to the oxisol horizons. In the analyzed material of the prismatic horizons features of illuviation of clay were not observed, although the particle size distribution indicated an increase of the clay content. The porostriated and granostriated b-fabric present in these horizons indicate that the soil have a high shrink and swell potential. 


\subsection{INTRODUÇÃO}

A micromorfologia é uma técnica de análise utilizada em estudos relacionados à gênese e desenvolvimento de solos, pois permite a observação, em escala micrométrica, dos constituintes dos agregados dos horizontes do solo e da alterita, bem como suas relaçōes e estágios de alteração (Castro et al., 2003). Além de contribuir em algumas deduções a respeito de processos pedológicos que possam estar ocorrendo nesta escala de estudo. Esta técnica é também utilizada em estudos relacionados à perda de massa de solo, bem como na prevenção de deslizamentos de encostas (Modenesi \& Toledo, 1996; Furian et al., 1999; Furian et al., 2002) e de formaçăo de voçorocas. Por isso, o uso da escala da microbacia em estudos relacionados ao funcionamento, uso sustentável e preservação dos recursos naturais, facilita a coleta de dados e torna possível estabelecer modelos conceituais (Bicudo et al., 2002) que facilitem a recuperação de áreas similares já degradadas e/ou em processo de degradação, freqüentes nas Serras do Mar e da Mantiqueira.

Neste trabalho a micromorfologia foi utilizada para estudar os horizontes prismáticos presentes em Latossolos de uma seqüência de solos (Figura 9), localizada na microbacia experimental "B" do Núcleo Cunha-Indaiá na Serra do Mar. Latossolos com horizontes de estrutura prismática que se desenvolvem no interior de horizontes com estrutura em blocos e subestrutura microagregada, com matizes avermelhados, pouca porosidade, com pequeno ou nenhum gradiente textural, e ausência de cutãs de iluviação, são pouco estudados. Além disso, não há na literatura um consenso quanto à origem dessas estruturas.

$\mathrm{Na}$ República dos Camarões ocorrem Latossolos com características similares, porém a estrutura é em blocos subangulares grandes (Müller, 1981). O processo de formação daqueles Latossolos é conhecido por micro estruturação e as estruturas denominadas microagregados estruturais. (Müller, 1981).

No sudoeste americano, alguns solos desenvolvidos sob clima árido, possuem horizontes com acúmulo de argila, mas não possuem evidências de 
argiluviação (argilãs) nos horizontes mais argilosos do perfil. A ausência de argilãs naqueles solos é devida ao alto potencial de expansão e contração, que impede a formação de argilãs nas faces dos peds e que são suficientemente permanentes para acumular argila e destruir quaisquer argilãs pré-existentes. Contudo, é evidente que aqueles solos foram formados a partir da iluviação de argila (Nettleton et al., 1969).

$\mathrm{Na}$ região norte do Brasil foram estudados latossolos com estruturas prismáticas em profundidade, de cor avermelhada, sem indicativos de processos de iluviação de argila, porem com aumento acentuado na fração argila (Chauvel et al., 1983).

\subsection{Material e métodos}

\subsubsection{Impregnaçăo das amostras}

As amostras indeformadas e orientadas dos horizontes, dos cinco perfis, foram coletadas em caixas do tipo Kubiena $(12 \times 7 \times 6 \mathrm{~cm})$ (Mermut, 1992).

Durante um período de 15 dias as amostras foram secas ao ar e posteriormente colocadas em estufa a $40{ }^{\circ} \mathrm{C}$ por mais 5 dias. $O$ material totalmente seco foi colocado em bandejas de alumínio a fim de iniciar o processo de impregnação.

A resina utilizada na impregnação é hidrofóbica, por isso foi necessária a total eliminação da água presente na amostra. Foi utilizada uma mistura de resina (epoxglass 1504) e de endurecedor (epoxglass 1601) na proporção de 5:1. As amostras nas bandejas receberam vagarosamente a solução com resina e, em seguida, foram colocadas em vácuo, com o propósito de impregnar a amostra por ascensão capilar, evitando ao máximo a formação de bolhas no seu interior.

O processo de impregnação teve duração de cerca de 4 horas, isto irá depender da textura e porosidade do solo. As amostras foram preenchidas 
totalmente pela resina e não havendo ocorrência de bolhas de ar, foram retiradas do vácuo e expostas ao ar.

\subsubsection{Confecção e descrição das lâminas delgadas}

Os blocos impregnados foram cortados com serra diamantada controlada automaticamente. As melhores áreas foram selecionadas e por meio de corte controlado manualmente, chegaram ao tamanho das lâminas de vidro (46 $\mathrm{mm} x$ $27 \mathrm{~mm}$ ). Os blocos colados às lâminas foram polidos até a espessura de $30 \mu \mathrm{m}$.

A descrição do material seguiu os critérios propostos por Bullock et al. (1985) e Stoops \& Jongerius (1975). As microfotografias foram obtidas com o auxílio de câmera Zeiss MC 63A acoplada ao microscópio petrográfico. Foi utilizada a sigla XPL para designar as fotomicrografias obtidas com nicóis cruzados (polarizador e analisador inseridos) e a sigla PPL para aquelas obtidas com a luz polarizada em único plano (polarizador inserido).

\subsubsection{Microscopia eletrónica de varredura (MEV) análise de imagem}

A possível ocorrência de nódulos e de depósitos gibbsíticos observados ao microscópio petrográfico, foi confirmada através da utilização do MEV acoplado a um sistema de microanálise por raios- $X$, por espectroscopia de energia dispersiva (EDS), que permitiu a realização de análises químicas. Tais análises foram realizadas a partir de fragmentos de agregados recobertos com um filme de ouro-paládio.

$O$ estudo da porosidade foi realizado, em lâminas delgadas do perfil 4 , a partir de imagens capturadas ao MEV, nos aumentos de 35 vezes $(1$ pixel $=$ $\left.2,86 \mu \mathrm{m}^{2}\right)$ e 100 vezes $\left(1\right.$ pixel $=1 \mu \mathrm{m}^{2}$ ), com doze repetiçðes. Estas imagens foram avaliadas com o uso de software para análise de imagem Noesis-Visilog 5.4 .

A classificação do tamanho dos poróides corresponde à divisão da porosidade total em classes de tamanho definidas por um aumento constante 
do logaritmo decimal da superfície dos poróides na razão de 1,78 (Cooper, 1999).

Foram utilizados dois índices de forma dos poróides. O primeiro índice (I2) foi definido por Coster \& Chermant (apud HALLAIRE \& CURMI, 1994):

$$
I_{l}=P^{2} /(4 \pi A)
$$

onde $P$ é o perímetro do poróide e $A$ a área que ocupa. Este índice é igual a um para uma forma perfeitamente circular, e é maior na medida em que a forma desvia-se do círculo. O segundo índice utilizado para definir a forma do poróide foi:

$$
I 2=\frac{\frac{1}{m} \sum_{i}\left(N_{l}\right) i}{\frac{1}{n} \sum_{j}\left(D_{F}\right) j}
$$

onde $m=$ número de direções $i$ nas quais são calculados o número de interceptos $N_{1}^{3},\left(i=0^{\circ}, 45^{\circ}, 90^{\circ}\right.$ e $\left.135^{\circ}\right)$ e $n=$ número de direçőes $j$ nas quais são calculados os diâmetros de Féret $D_{F}^{4},\left(j=0^{\circ}\right.$ e $\left.90^{\circ}\right)$

$O$ índice $I_{2}$ foi utilizado como complemento ao índice $I_{1}$ a fim de refinar as classes de poróides (Tabela 7).

Canais, cavidades isoladas e poros tubulares que apresentam indice de forma $l_{1} \leq 5$, compreendem a classe morfológica Arr (poróides arredondados). A porosidade resultante da assembléia de agregados e/ou de partículas elementares e de poros de diversos tipos interconectados, que formam uma rede poral de tamanho grande e de formas muito contornadas, com índice de forma $l_{1}>25$, săo classificados como Comp (poróides complexos). No índice de forma $5<l_{1} \leq 25$ coexistem poróides alongados e complexos. Por isso, foi

\footnotetext{
${ }^{3}$ O número de interceptos, $N_{h}$ de um objeto na direção $i$ é o número de entradas naquele objeto ao longo de retas paralelas à direçăo $i$.

${ }^{4}$ O diâmetro de Féret, $D_{F}$, de um objeto numa direção jé a distancia entre duas tangentes paralelas à direção je enquadrando o contomo do objeto.
} 
proposto por Cooper (1999), o indice $I_{2}$ a fim de diferenciá-los. A tabela 6 mostra as três classes de forma dos porbides e a tabela 8 estão as classes de tamanhos dos poróides.

Tabela 7 - Definição das classes de forma dos poróides

\begin{tabular}{ccc} 
Porbides & \multicolumn{2}{c}{ Índices de forma } \\
& $l_{1}$ & $l_{2}$ \\
\hline Arredondados (Arr) & $5<l_{1} \leq 25$ & $\leq 2,2$ \\
Alongados (Alon) & $5<l_{1} \leq 25$ ou $>25$ & $>2,2$ \\
Complexos (Comp) &
\end{tabular}

Tabela 8 - Definição das classes de tamanho versus forma dos poróides

\begin{tabular}{|c|c|c|c|c|}
\hline \multicolumn{2}{|c|}{ Limites das classes de tamanho em $\mu^{2}$} & \multicolumn{3}{|c|}{ Classes de forma } \\
\hline $35 x$ & $100 x$ & Arredondados & Alongados & Complexos \\
\hline $\begin{array}{c}8-800 \\
800-8000 \\
>8000\end{array}$ & $\begin{array}{c}1-100 \\
100-1000 \\
>1000\end{array}$ & $\begin{array}{l}A r_{p(1)} \\
A r_{m(2)} \\
A r_{p(3)}\end{array}$ & $\begin{array}{l}\text { Alon }_{p} \\
\text { Alon } \\
\text { Alon }_{\mathrm{q}}\end{array}$ & $\begin{array}{l}\text { Comp }_{p} \\
\text { Comp } \\
\text { Comp } \\
\text { com }\end{array}$ \\
\hline
\end{tabular}

(1) $p=$ pequeno

(2) $m=$ médio.

(8) $g=$ grande.

\subsection{Resultados e discussão}

\subsubsection{Descrição micromorfológica dos perfis de solo}

As descrições do material coletado nos perfis estão organizadas de montante a jusante da toposseqüência e da base em direção ao topo do perfil.

\section{Perfil 5}

O horizonte $\mathbf{C}$ tem contextura porfírica simples e microestrutura maciça. Plasma gibbsítico é manchado por material ferruginoso. Não foi observada a presença de argila no plasma. Observa-se presença de poro preenchido por gibbsita micro-cristalina (neoformação) (Figura 14a). $O$ esqueleto mal selecionado é constituído por grãos de quartzo trincados e por raros fragmentos de mica.

A contextura do horizonte BC é porfírica simples. A microestrutura é maciça. Apresenta plasma gibbsítico ligeiramente ferruginizado. $O$ esqueleto, 
pobremente selecionado, é constituído predominantemente por fragmentos de quartzo e por raros grãos de muscovita, alguns em alteração.

O horizonte Bw2 apresenta cor vermelha e contextura porfírica. A microestrutura é do tipo complexa entre microagregados e blocos subangulares. O plasma é isótico. Canais e câmaras constituem a porosidade. O esqueleto é pobremente selecionado, onde predominam os grăos de quartzo, trincados e com produtos ferruginosos em algumas descontinuidades cristalinas, e raros grãos de mica.

O horizonte Bw1 também homogêneo, de cor bruno-avermelhado e contextura porfírica. Apresenta microestrutura complexa constituída por microagregados com pedalidade forte e por blocos subangulares com grau de pedalidade fraca. O plasma é isótico sem fábrica birrefringente. Há fragmentos de mica que chegam à fração argila e sob luz polarizada podem parecer fábricas birrefringentes. Os poros são do tipo fissural e empacotamento complexo, dominante. $O$ esqueleto é composto predominantemente por fragmentos de quartzo pobremente selecionados, alguns trincados e com produtos ferruginosos em algumas descontinuidades cristalinas, além de fragmentos de muscovita em alteração (Figura 14b), também pobremente selecionados.

O material analisado do horizonte BA é homogêneo, de cor bruno escuro e com contextura porfírica. Apresenta microestrutura complexa formada por microagregados com pedalidade forte e por blocos subangulares com pedalidade fraca (Figuras $15 \mathrm{a} \mathrm{e} \mathrm{b)}$ ). O plasma é isótico. A porosidade é do tipo fissural e empacotamento complexo. O esqueleto é pobremente selecionado, há predomínio de quartzo, muitos trincados e com produtos ferruginosos em algumas descontinuidades cristalinas. A atividade biológica é intensa, há muito pedotúbulos com preenchimento solto e descontínuo. 
PPL

XPL
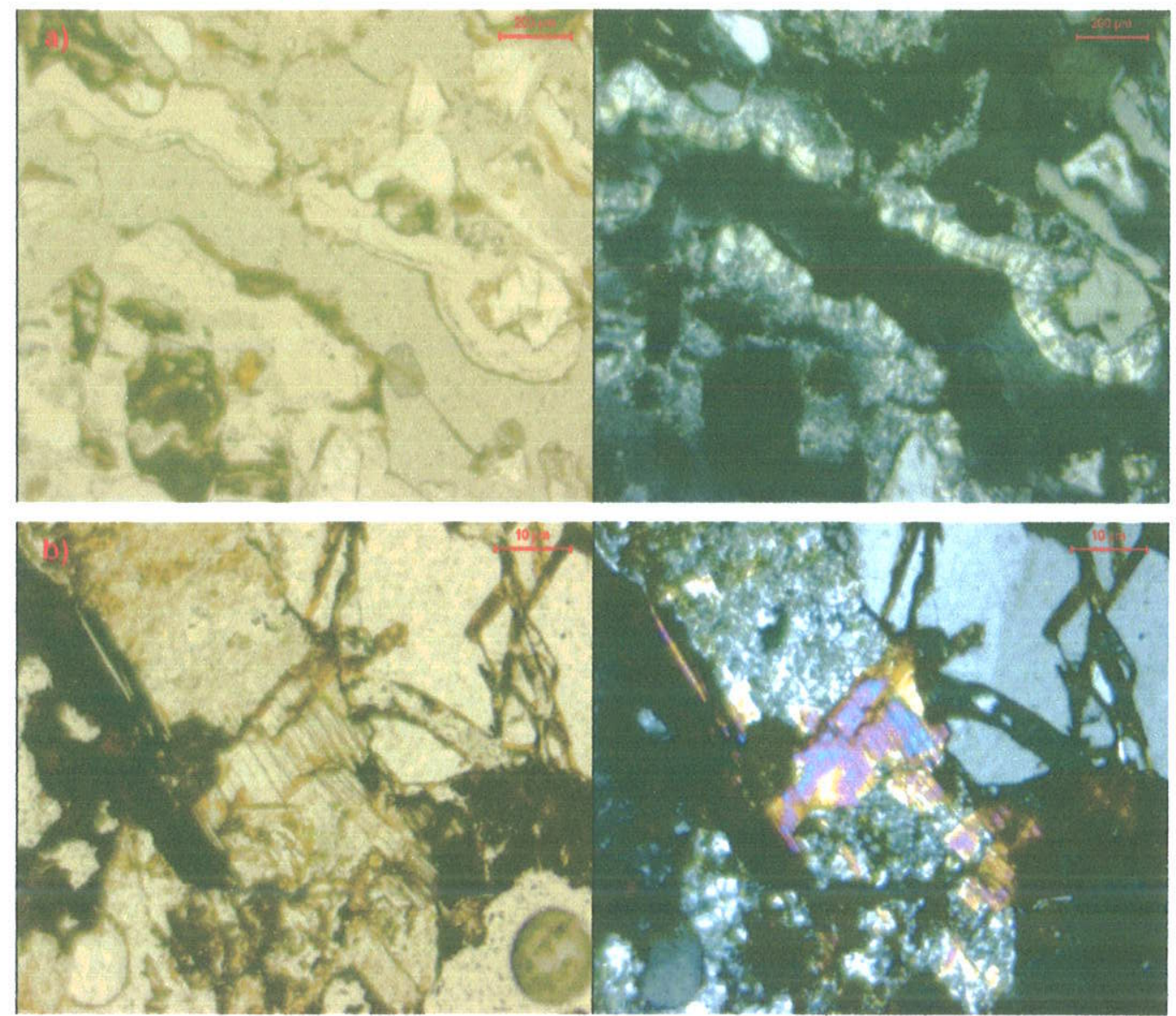

Figura 14 - Fotomicrografias: (a) poro preenchido por gibbsita micro cristalina (b) muscovita em alteração e fragmento de quartzo trincado.

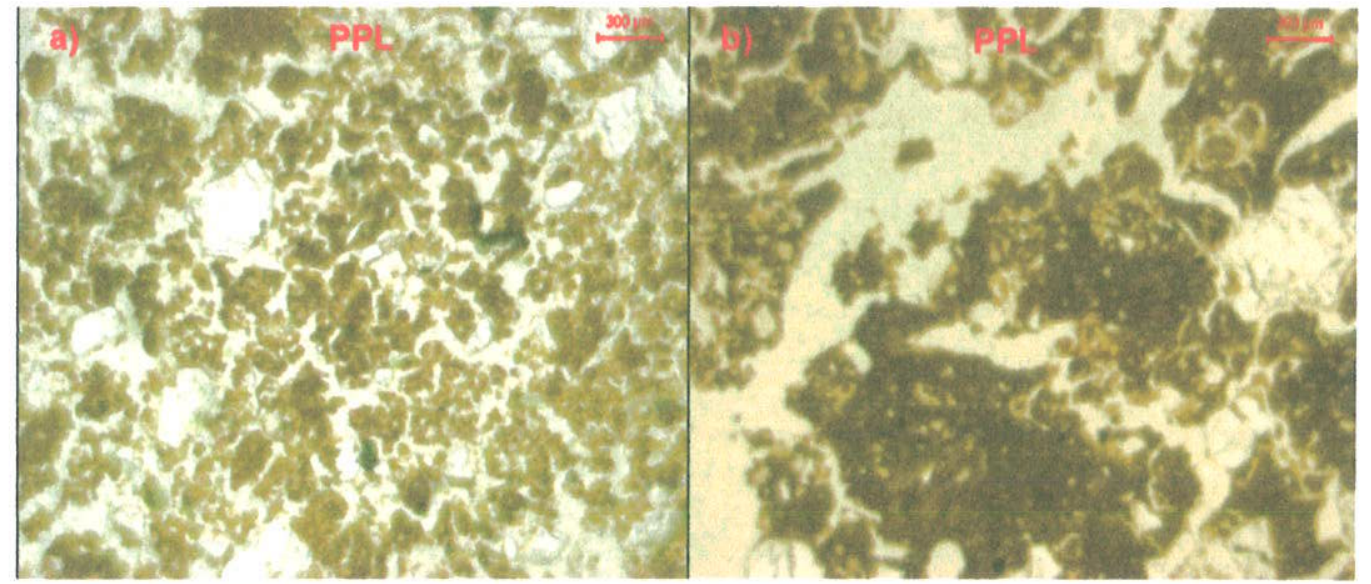

Figura 15 - Fotomicrografias: subangulares.

(a) microagregados e (b) blocos 


\section{Perfil 6}

O material do horizonte $\mathrm{Bw}$ tem matiz 7,5YR e contextura porfírica. A microestrutura complexa é constituída por microagregados com pedalidade forte e por blocos subangulares com grau de pedalidade fraca. O plasma é isótico sem fábrica birrefringente e em algumas áreas, manchado pela matéria orgånica. A porosidade é do tipo empacotamento complexo, dominante, e fissural. $O$ esqueleto é composto por fragmentos de quartzo pobremente selecionados e com produtos ferruginosos em algumas descontinuidades cristalinas, além de grăos de mica em estágios diferentes de alteração. A atividade biológica é intensa com presença de inúmeros pedotúbulos e de muitos restos de raízes.

\section{Perfil 13}

O horizonte Bn2 possui matiz 5YR e contextura porfírica. A microestrutura é prismática e o plasma é isótico com fábricas birrefringentes estriada cruzada, granoestriada e poroestriada. A porosidade é do tipo fissural. $O$ esqueleto é constituído por quartzo e mica.

A contextura do horizonte de transição Bn2/Bn1 é porfíica e a cor é menos avermelhada, matiz $6 Y R$. O plasma é isótico com fábricas birrefringentes do tipo salpicada, estriada cruzada, poroestriada e granoestriada. A porosidade é fissural $e$ o esqueleto é constituído por grãos de quartzo trincados e com produtos ferruginosos em algumas descontinuidades cristalinas, além de fragmentos de mica.

No horizonte Bn1 a contextura é porfírica e o matiz 7,5YR. O horizonte apresenta microestrutura prismática e plasma isótico com fábrica birrefringente salpicada, estriada cruzada, granoestriada e poroestriada. A porosidade é do tipo fissural e o esqueleto é constituído por fragmentos de quartzo trincados e com produtos ferruginosos em algumas descontinuidades cristalinas, além de mica em diferentes estágios de alteração. 
$O$ horizonte de trans'içăo Bn1/Bw2 possui contextura porfírica e matiz 7,5YR. A microestrutura é complexa, entre microagregados e prismas, e o plasma é isótico com fábricas birrefringentes: salpicada, estriada cruzada, poroestriada e granoestriada. A porosidade é fissural na área dos prismáticos e empacotamento na área dos microagregados. Fragmentos de quartzo constituem o esqueleto.

No horizonte Bw2 a contextura é porfi-enáulica e o matiz 7,5YR. A microestrutura é em blocos subangulares com moderado grau de pedalidade. Em campo, as feições de contração e expansão do material não foram observadas. No entanto, ao microscópio observou-se plasma isótico com fábricas birrefringentes: estriada cruzada, granoestriada e poroestriada. A porosidade é constituída por canais e fissuras. O esqueleto é composto por quartzo.

A contextura do horizonte Bw1 é enáulica e o matiz 7,5 YR. A microestrutura é complexa entre blocos subangulares e microagregados. $O$ plasma é isótico e a porosidade em canais, fissuras e empacotamento complexo. O esqueleto é formado por grãos de quartzo pobremente selecionados, trincados e com produtos ferruginosos em algumas descontinuidades cristalinas, além de mica em diferentes estágios de alteração. Presença de atividade biológica

O horizonte BA é homogêneo, com contextura porfírica e cor bruno escuro. Possui microestrutura complexa formada por microagregados com pedalidade forte e por blocos subangulares com pedalidade fraca. O plasma é isótico e a porosidade é constituída por fissuras e empacotamento complexo. $O$ esqueleto é pobremente selecionado, onde predomina o quartzo, muitos trincados e com produtos ferruginosos em algumas descontinuidades cristalinas. Atividade biológica é intensa com muitos pedotúbulos com preenchimento solto e descontínuo. 


\section{Perfil 4}

Embora em campo o horizonte Bn3 apresente estrutura prismática visivelmente menos nítida, micromorfologicamente as evidências de contração e expansão são bastante intensas, há fábricas birrefringentes estriada cruzada, poroestriada e granoestriada (Figura 16a). A contextura é porfírica e a cor 7,5YR. A microestrutura é maciça e o plasma é isótico com algumas manchas mais escuras. O esqueleto é constituído por grãos de quartzo e poucos fragmentos de biotita. Presença de numerosos domínios gibbsíticos (Figura 16b), alguns manchados por material ferruginoso.

Este horizonte Bn2, além da mudança de cor para o matiz 5YR, possui porosidade fissural ainda menor, e as evidências de contração e expansão apresentam-se ainda mais marcantes. A microestrutura é maciça e o plasma isótico com fábricas birrefringentes estriadas cruzadas, poroestriadas e granoestriadas. O esqueleto possui quartzo, muscovita, biotita e poucos fragmentos de feldspato.

O horizonte Bn1 apresenta contextura porfírica e cor volta a 7,5YR. Possui microestrutura maciça e o plasma isótico com fábricas birrefringentes salpicada, estriada cruzada, granoestriada e poroestriada, que são evidências de que o material sofre expansão e contração. Aqui as fábricas birrefringentes apresentam maior intensidade, enquanto a porosidade fissural diminui ainda mais. $O$ esqueleto é constituído por fragmentos de quartzo trincados e com produtos ferruginosos em algumas descontinuidades cristalinas e por fragmentos de biotita, alguns sãos. 
produtos ferruginosos em algumas descontinuidades cristalinas e por fragmentos de biotita, alguns sãos.
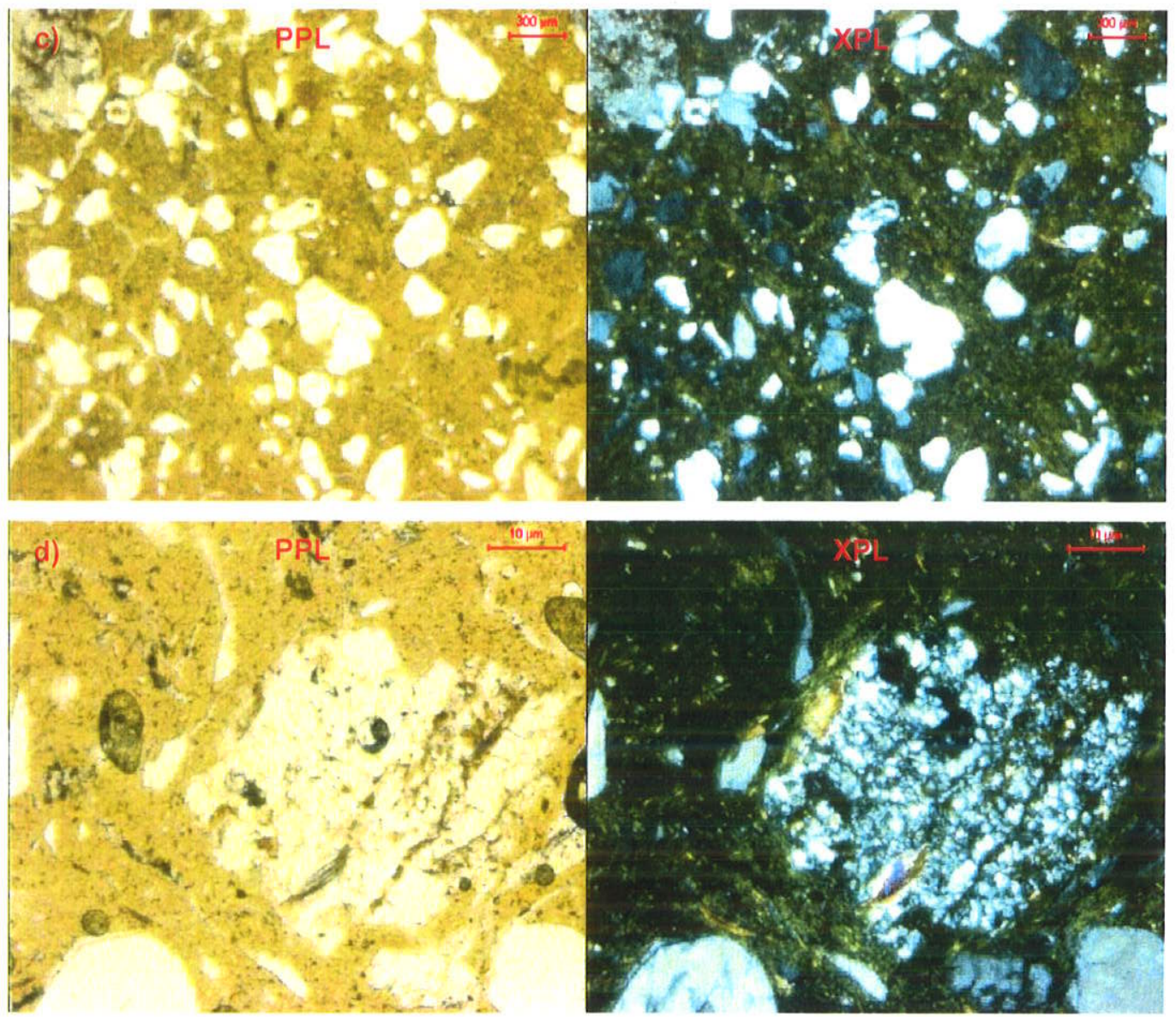

Figura 16 - Fotomicrografias: (a) evidências de expansão e contração do material e (b) domínios gibbsíticos.

Na transição entre horizontes Bn1 e Bw2 não foi possível observar as estruturas prismáticas em função do tamanho da secção delgada. Possui contextura porfírica e microestrutura maciça. O plasma isótico possui fábricas birrefringentes salpicada, granoestriada e poroestriada. A porosidade total é um pouco maior em relação ao horizonte anterior (Figura 17a), com fissuras entre agregados e presença de fissuras grandes, provavelmente, devido ao processo de desidratação do material. O esqueleto é constituído por quartzo.

A contextura do horizonte Bw2 é enáulica e a cor 7,5YR. A microestrutura é blocos subangulares com grau de pedalidade de moderada a 
(Figura 17c), embora, em campo, feições de contração e expansão do material não tenham sido observadas. Nota-se a presença de canais delimitando os blocos e porosidade fissural interagregados. O esqueleto é formado por fragmentos de quartzo trincados e com produtos ferruginosos em algumas descontinuidades cristalinas, por mica e por poucos grăos de feldspato. Verifica-se a presença de fragmentos de feldspato são e de um pseudomorfo de feldspato alterado para gibbsita com início de ferruginização. Há fragmentos de mica espalhados sobre o plasma, em diferentes estágios de alteração, observados pelo gradiente de pleucroísmo. Há marcante adensamento em relação ao horizonte $\mathrm{BA}$ e diminuição da atividade biológica.

O horizonte Bw1 de cor 10YR apresenta contextura porfi-enáulica. Microestrutura complexa entre blocos angulares a subangulares com grau de pedalidade fraco e microagregados com pedalidade bem desenvolvida (figura 17d). O plasma é isótico. A porosidade é do tipo empacotamento complexo e canais. $O$ esqueleto é pobremente selecionado com predomínio de fragmentos de quartzo, muitos trincados e com produtos ferruginosos em algumas descontinuidades cristalinas. Há ainda fragmentos de mica espalhados pelo plasma, alguns pouco alterados, com pleucroísmo alto. Atividade biológica é intensa com muitos pedotúbulos do tipo solto descontínuo.

O horizonte BA apresenta contextura porfírica e cor 7,5YR. Microestrutura formada por microagregados. O plasma é isótico e a porosidade é do tipo empacotamento complexo. O esqueleto é pobremente selecionado, onde predomina o quartzo, muitos trincados e com produtos ferruginosos em algumas descontinuidades cristalinas. Atividade biológica é intensa com muitos pedotúbulos com preenchimento solto e descontínuo (Figura 17e). 

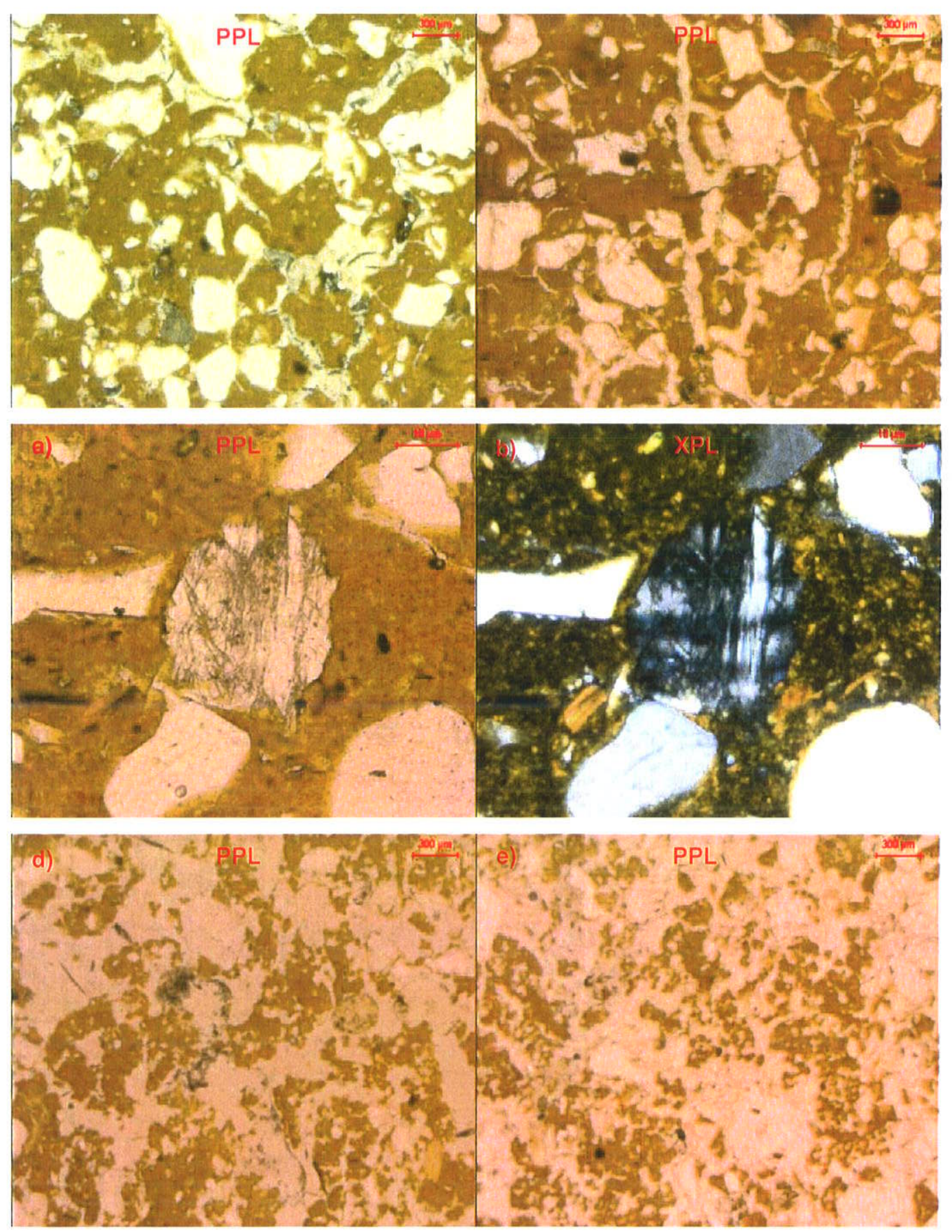

Figura 17 - Fotomicrografias: (a) e (b) mudança de cor e aumento da porosidade entre o horizonte Bw2 e a transição Bn1/Bw2 (c) evidências de expansão e contração do material ao redor do esqueleto, (d) microestrutura complexa e (e) pedotúbulos. 


\section{Perfil 2}

No horizonte C, o material da isoalterita é constituido por plasma isótico, por porosidade de canais e fissuras. Basicamente, o esqueleto (Figura 18a) é formado por muitos grãos de quartzo bastante fraturados, por alguns grãos de biotita sã e por fragmentos de biotita espalhados sobre o plasma e por pseudomorfos (Figura 18b), também de biotita, além de fragmentos de microclínio são (Figura 18c) e em alteração. Observa-se a ocorrência de alguns nódulos gibbsíticos.

O material do horizonte BC é constituído por plasma isótico e por porosidade do tipo canais e fissuras. A contextura é porfírica e a microestrutura é maciça. O plasma é nitidamente mais abundante e com fábricas birrefringentes de padrão salpicado, granoestritado e poroestriado (Figura 19a). O esqueleto é composto por fragmentos de quartzo mal selecionados, e por biotita e microclínio em diferentes estágios de alteração.

No horizonte Bi2 a contextura é porfírica e a estrutura maciça com pequena tendência à formação de blocos subangulares. O plasma é ainda mais abundante, é isótico e com os mesmos padrões das fábricas birrefringentes do horizonte anterior. A porosidade é variada: canais, fissuras e câmaras. $O$ esqueleto possui muitos fragmentos de mica să, pseudomorfos de mica, fragmentos de mica espalhados no plasma, microclínio e muitos grãos de quartzo (Figura 19b). Feiçð̋es pedológicas amorfas de magnetita (opacos) são observadas.

O horizonte Bi1 apresenta matiz 6YR e contextura porfi-enáulica. A microestrutura é complexa, nas zonas mais densas há tendência à formação de blocos subangulares $e$ as zonas mais abertas correspondem aos microagregados. O plasma é isótico com fábrica birrefringente salpicada. A porosidade é do tipo canais, fissuras e empacotamento complexo. $O$ esqueleto possui muitos fragmentos de mica alterada, alguns fragmentos de mica sã, pseudomorfos de mica, fragmentos de mica espalhados no plasma, alguns 
grãos de feldspato e muitos fragmentos de quartzo. Observa-se presença de nódulo de ferro com fragmentos de mica (Figura 19c).
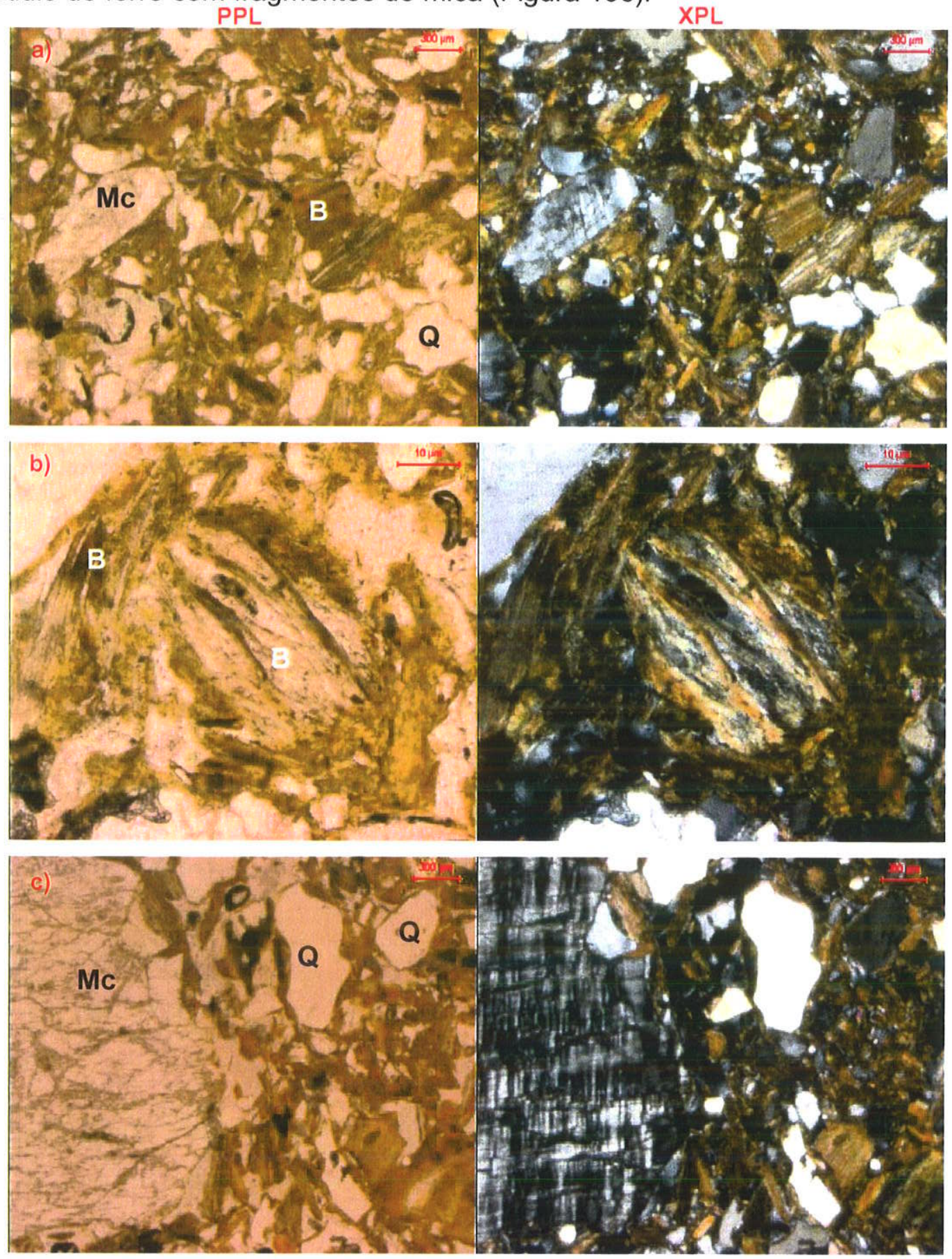

Figura 18 - Fotomicrografias: (a) esqueleto constituído por microclínio $(\mathrm{Mc})$, biotita $(B)$ e quartzo $(\mathrm{Q})$, (b) biotita $(B)$ em alteração e (c) microclínio (Mc) ao lado de fragmentos de quartzo $(Q)$ e de biotita. 

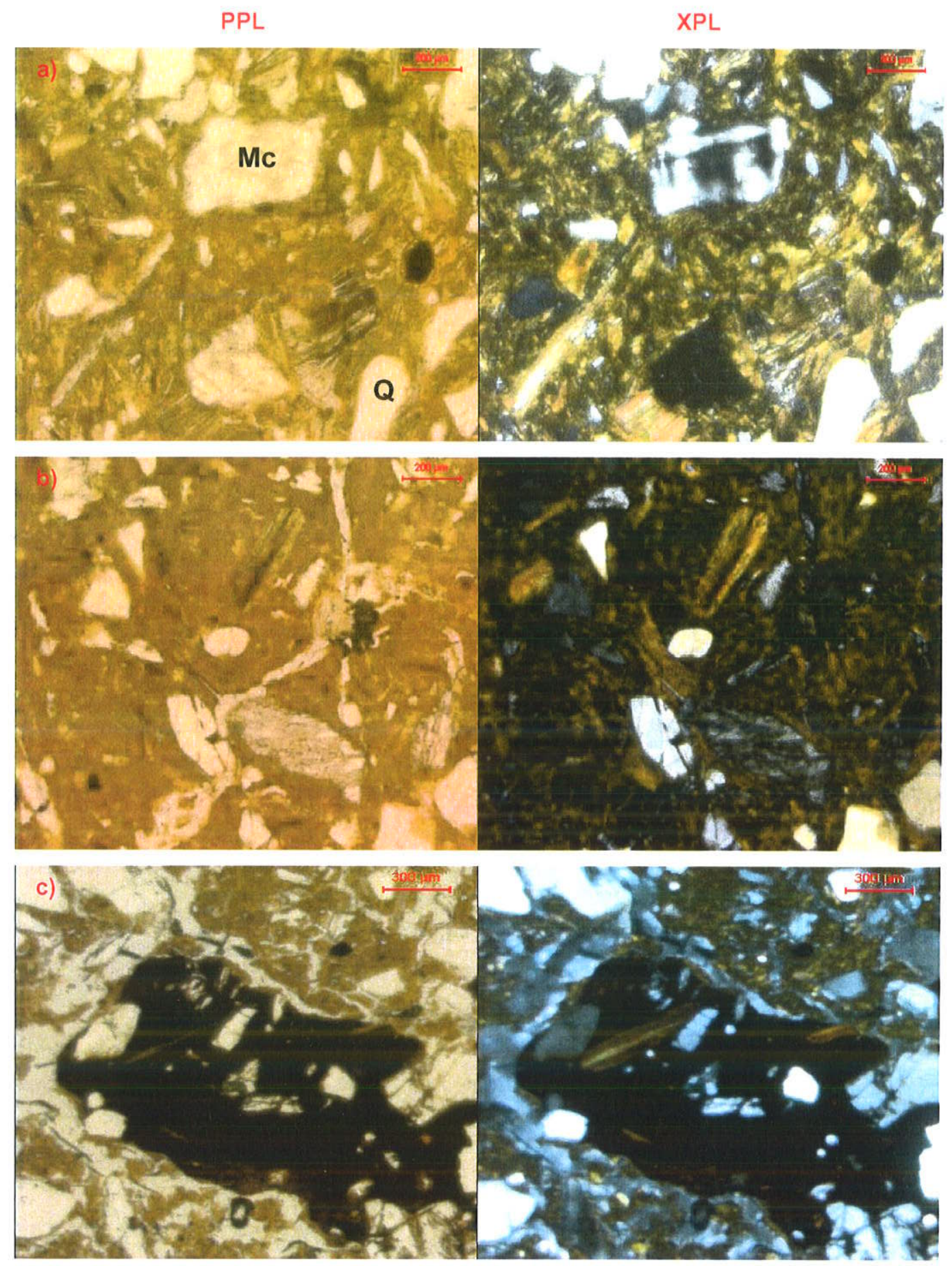

Figura 19 - Fotomicrografias: (a) esqueleto constituído por microclínio (Mc), biotita e quartzo (Q), (b) plasma mais abundante e (c) nódulo de ferro com fragmentos de mica.

A contextura do horizonte BA é porfi-enáulica e a cor 10YR. A microestrutura é complexa entre blocos angulares a subangulares com grau de 
pedalidade fraco e microagregados com pedalidade bem desenvolvida. 0 plasma isótico possui fragmentos de biotita, que podem alcançar a fração argila. Neste horizonte a fábrica birrefringente é salpicada. O material grosseiro é constituído por fragmentos de mica em diferentes estágios de intemperismo e por poucos grãos de feldspato, além dos grãos de quartzo trincados e com produtos ferruginosos em algumas descontinuidades cristalinas. Atividade biológica é intensa com pedotúbulos dentro de pedotúbulos e presença de muitas raízes.

\subsubsection{Sintese das descriçס̃es}

Além do material dos perfis de solo, foi descrito também o material de alteração, bem como da rocha sã. O material original é um granito-gnaisse de textura porfírica, constituído por quartzo, mica (biotita e muscovita), feldspato e por alguns grãos de granada.

Verificou-se, no esqueleto do material de alteração, a ocorrência de fragmentos de quartzo pobremente selecionados, de mica (biotita, muscovita), de microclínio são com ferruginização (Figura 20a), de microclínio sericitizado e de raros fragmentos de granada alterados (Figura 20a). Os pseudomorfos de biotita mostraram a associação mineralógica biotita, biotita alterada (vermiculita) e caolinita (Figuras $20 \mathrm{~b}$ e 20c). A ferruginização ao longo das descontinuidades dos cristais de biotita, como espaços interlamelares (planos de clivagem) e fissuras, bem como em fragmentos de biotita sã, marcam 0 início do intemperismo da mica (Figura 21a) (Le Pera et al., 2001). Num estágio mais avançado de intemperismo, a alteração do feldspato e da mica exerce importante influência sobre a microfábrica, através da desintegração da rocha, o que leva ao processo de arenização (Taylor \& Howard, 1999; Furian et al., 1999; Le Pera et al., 2001).

A fábrica birrefringente do tipo estriada cruzada, observada em horizontes prismáticos dos perfis 4 e 13, também foi observada em Latossolos do Pará desenvolvidos a partir de granitos. Nos solos do Pará estes padrões de 
fábricas birrefringentes encontram-se, em profundidade no perfil, onde as tensões internas são fortes e a porosidade intragregado é menor quando comparada ao volume da variação causada pelos ciclos de contração e expansão do solo (Chauvel et al., 1983). Estas feições podem, ainda, ter sido originadas a partir da alteração de feldspato em sericita, o que pode ser melhor observado em grãos de feldspato mais preservado, onde a sericitização ocorre ao longo dos planos de fratura (Figura 21b), o que é menos evidente nos grãos mais alterados (Le Pêra et al., 2001).

$\mathrm{Na}$ República dos Camarōes ocorrem Latossolos com características similares, porém a estrutura é em blocos subangulares grandes (Müller, 1981). O processo de formação daqueles Latossolos é conhecido por microestruturação e as estruturas denominadas microagregados estruturais. Assim, as fábricas birrefringentes estriadas cruzadas, observadas no presente trabalho, podem estar relacionadas à primeira fase do processo de microestruturação. Portanto, os padrões de fábricas birrefringentes presentes nos horizontes prismáticos podem ter sido originados tanto a partir dos ciclos de umedecimento e secamento como do material de origem (Brewer, 1960; Mermut, 1992).

\subsubsection{Análise de imagens}

Tanto as observações de campo como as descrições das lâminas delgadas mostraram a mudança de estrutura e a diminuição do espaço poral dos horizontes $\mathrm{BW}$ em direção aos horizontes $\mathrm{Bn}$, nos perfis 13 e 4 .

Os resultados de porosidade total (PT) indicam que, nos dois aumentos (35x e 100x), nẫo há diferença estatística entre os horizontes prismáticos (Bn1, Bn2 e Bn3) (Figura 22). 

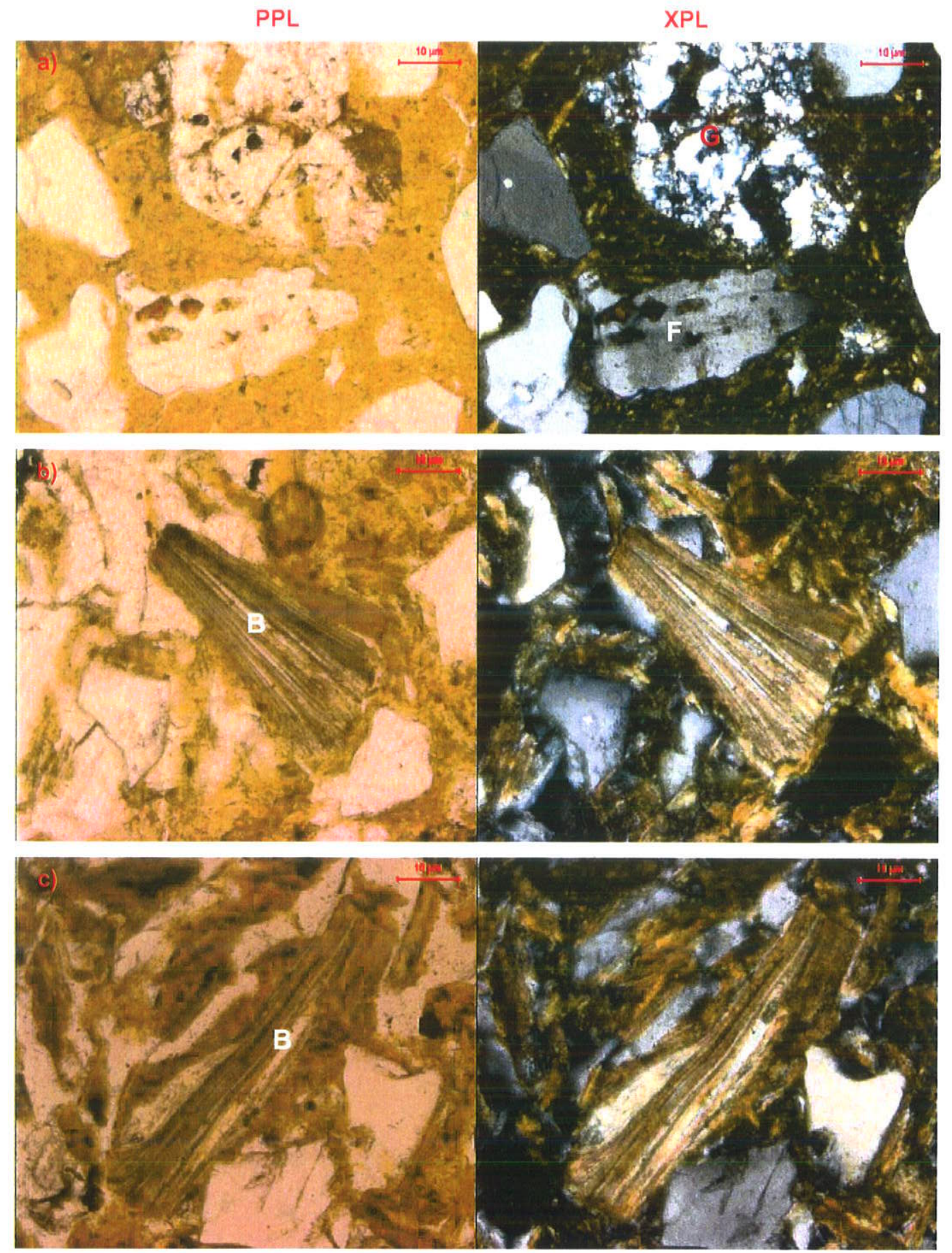

Figura 20 - Fotomicrografias: (a) granada alterada (G) ao lado de feldspato (F) ferruginizado, (b) e (c) pseudomorfos de biotita (B). 
PPL

XPL
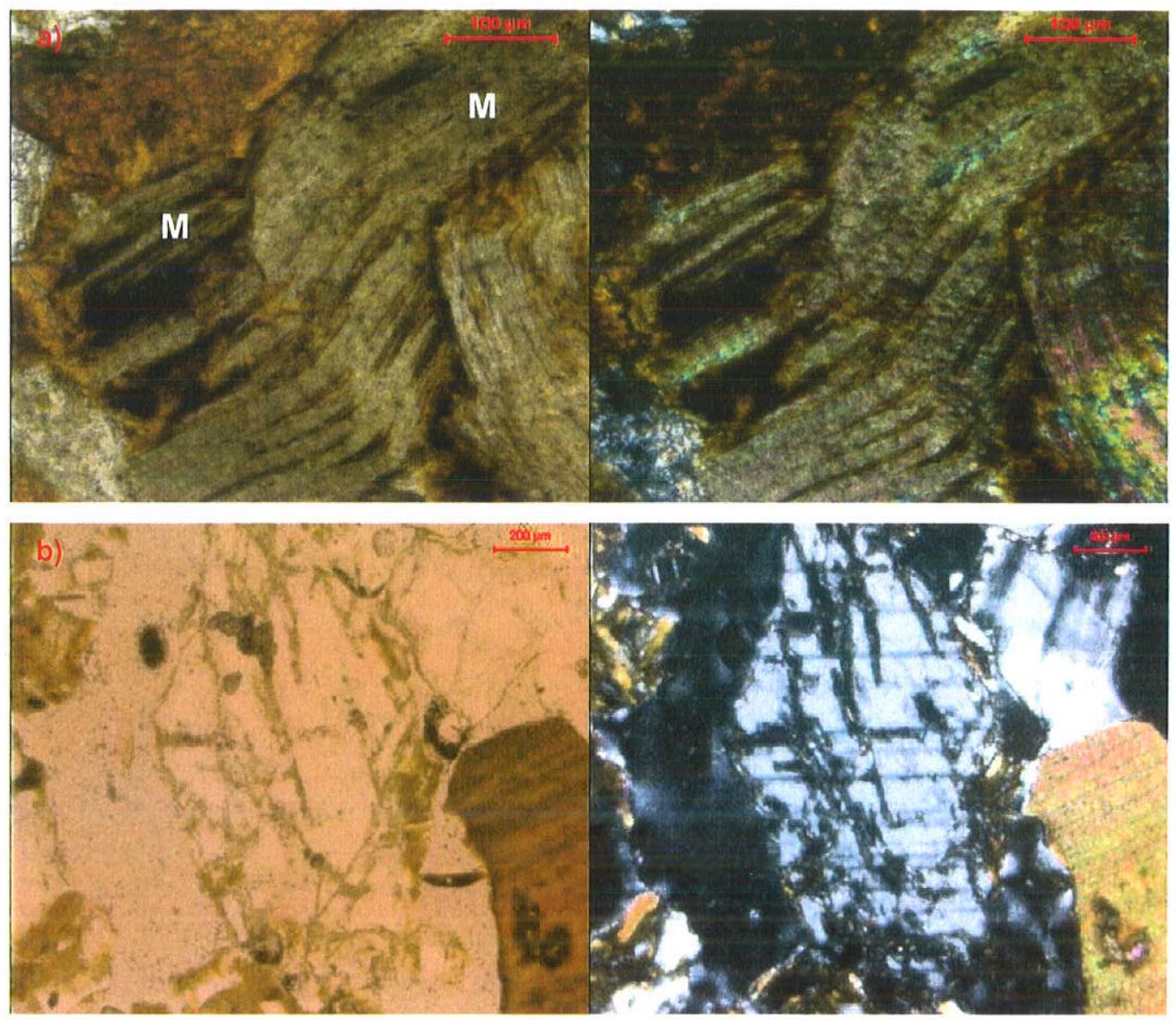

Figura 21 - Fotomicrografias: (a) mica em alteração com ferruginização e (b) princípio da alteração de microclínio em sericita ao lado de biotita sã.

O horizonte Bw2 apresenta uma PT de 11,64\% (35x) e de 13,64\% (100x), o que é significativamente maior que a PT do Bn1 de 6,55 \% (35x) e de 6,61 \% (100x) (Figura 20). Além da diminuição da PT entre os horizontes Bw e $\mathrm{Bn}$, a figura 21 mostra que o percentual de poróides complexos também diminuiu nos dois aumentos (35x e 100x). A presença de poróides alongados é um importante indicativo de movimentos de contração e expansão do solo (Murphy et al., 1977 a e b), assim podemos inferir que a origem dos horizontes prismáticos não está relacionada a tais movimentos. Estudos realizados na microabacia " $D$ " mostraram que há diminuição da porosidade total entre os 
horizontes gibbsíticos (40\%) e os cauliníticos (51\%) (Furian et al., 1999), mas não tão acentuada como os valores mostrados na figura 23.
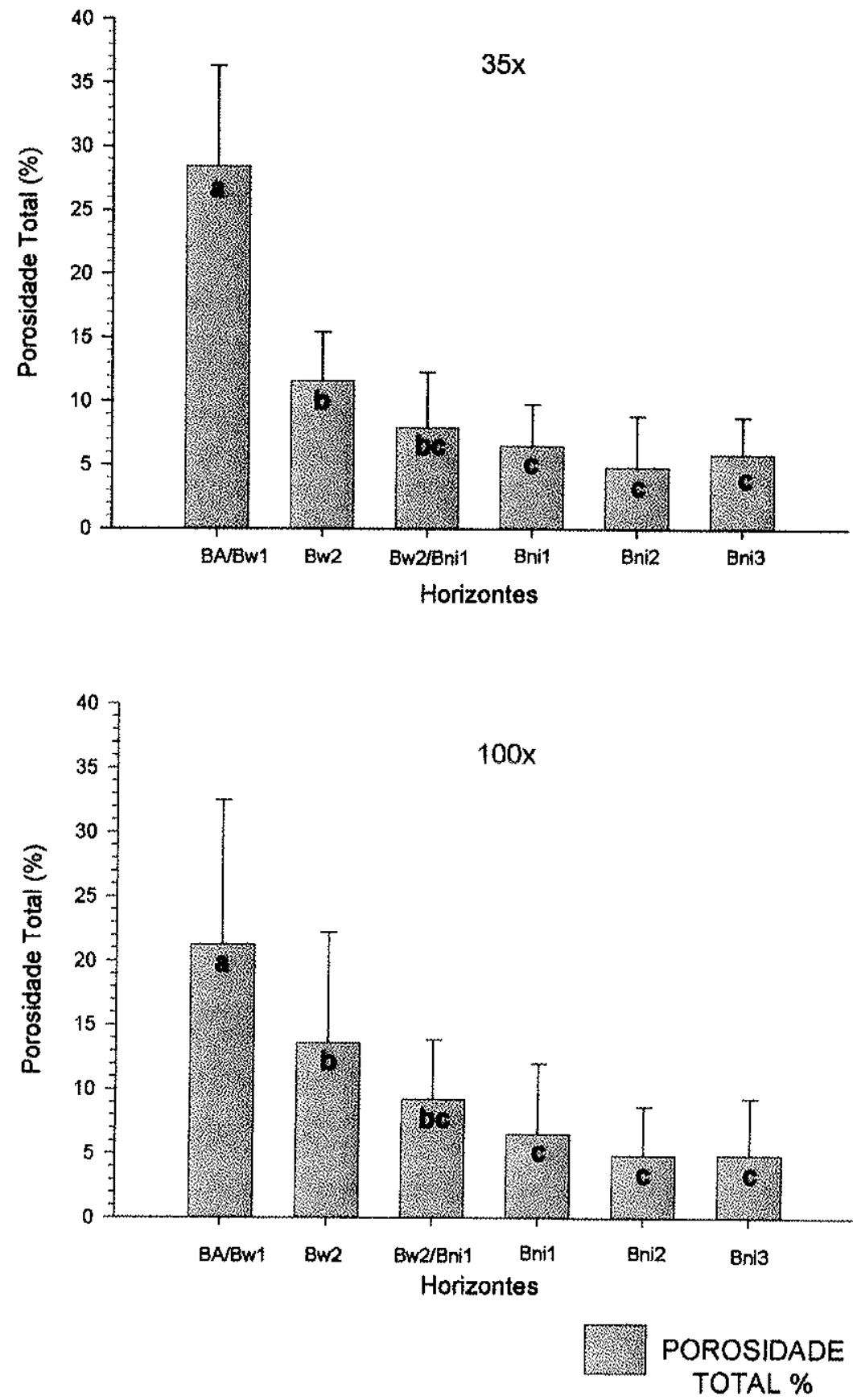

Figura 22 - Média da porosidade total e desvio padrăo dos horizontes do perfil 4 (Latossolo Amarelo Distrófico argissólico). A partir do teste de Tukey, as médias dos horizontes, que possuem a mesma letra, não diferem entre si a $5 \%$ 


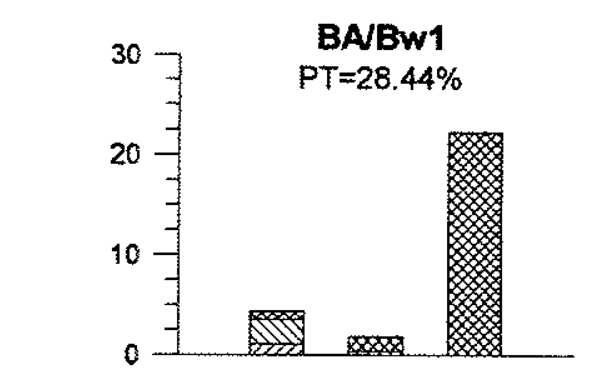

$35 x$
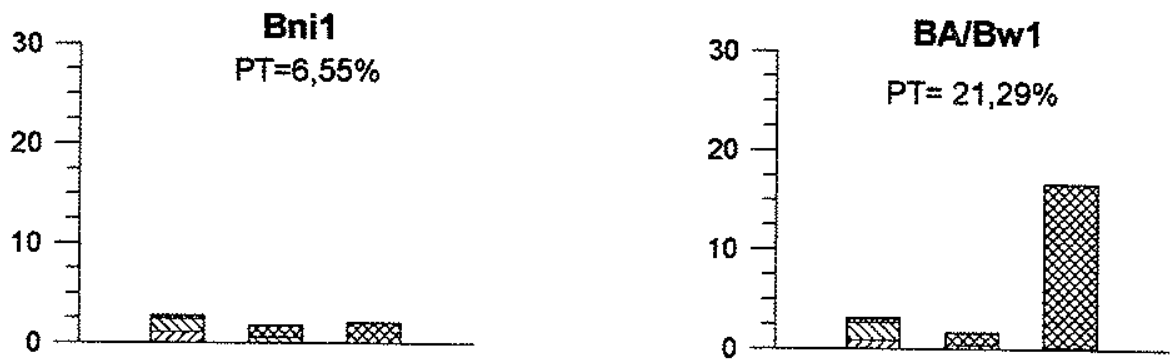

$100 x$

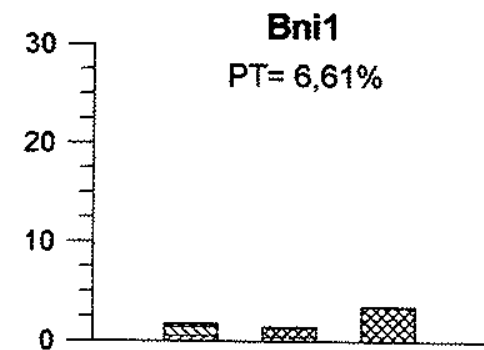

$\stackrel{0}{0}$
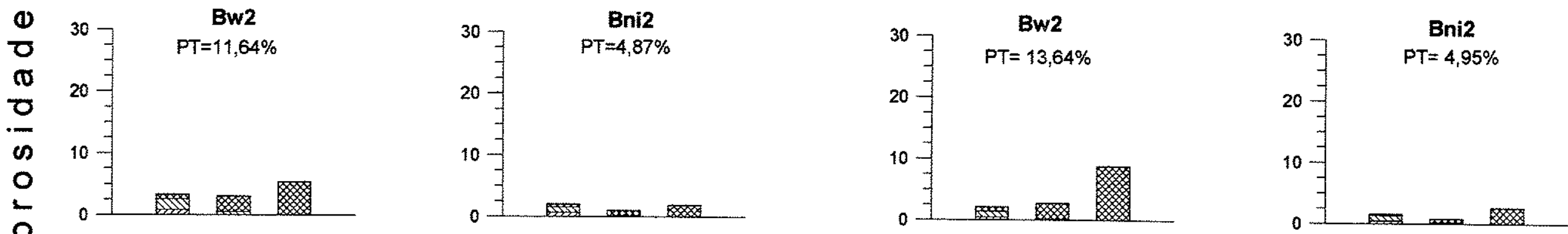

a.
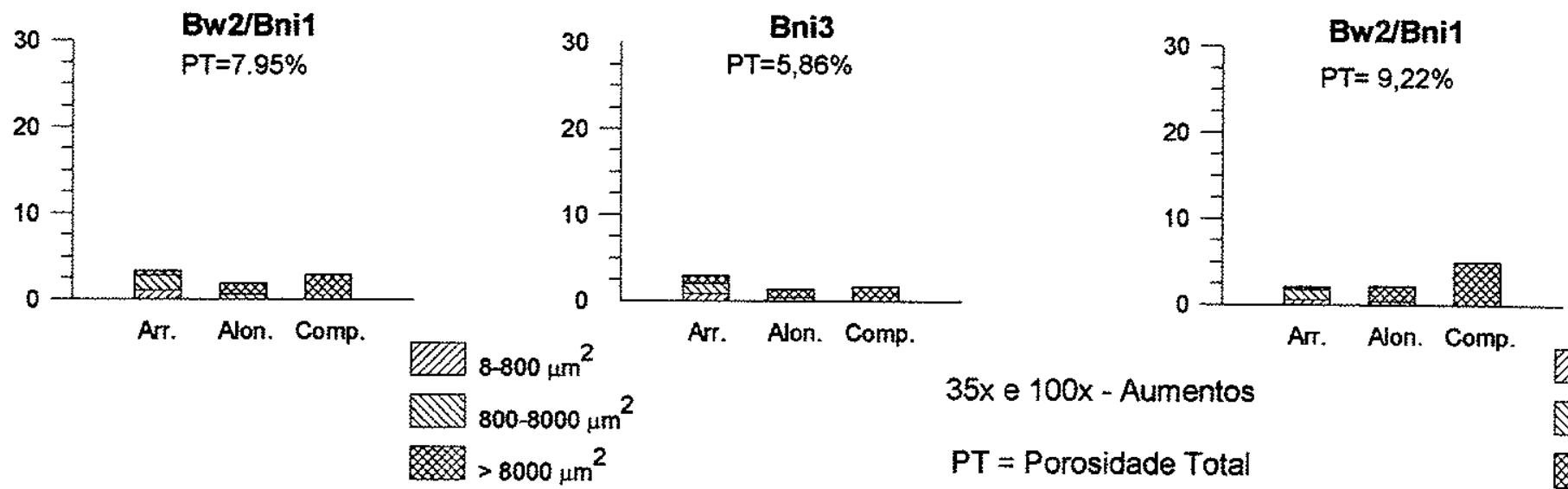

Arr. Alon. Comp.

Arr. Alon. Comp.

$35 x$ e $100 x$ - Aumentos

PT = Porosidade Total

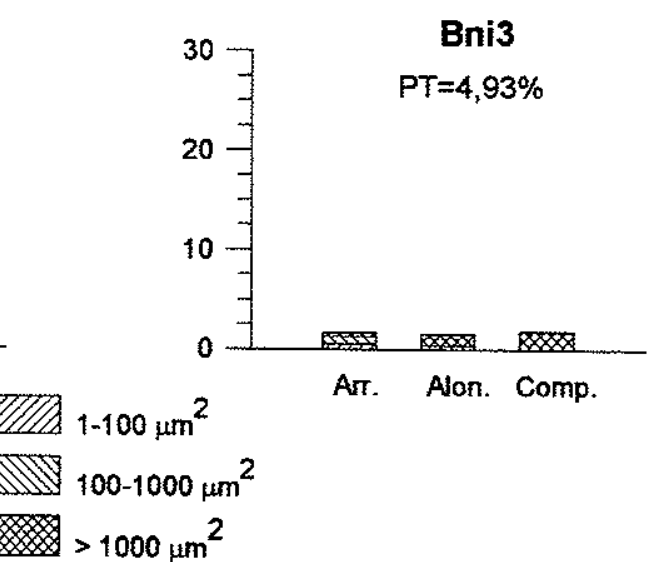

Figura 23 - Distribuição da porosidade total, dos horizontes do perfil 4 (Latossolo Amarelo Distrófico argissólico), em função da forma e do tamanho dos poróides. Arre $=$ arredondados, Along. $=$ alongados e Comp $=$ complexos 


\subsubsection{Conclusåo}

As descrições das lâminas delgadas do material de origem $e$ da alteração mostraram uma assembléia mineralógica simples (quartzo, feldspato, mica e granada) que se encontra em diferentes estágios de intemperismo. $O$ material pedológico é formado por plasma isótico nos horizontes superficiais sem fábrica birrefringente e nos prismáticos por plasma com fábricas birrefringentes do tipo estriada cruzada, poroestriada e granoestriada, que sugerem a ocorrência de movimentos de expansão e contração do solo.

No entanto, os resultados de análise de imagem mostraram que apesar de a PT ter diminuido nos prismáticos, não é possível afirmar que, as estruturas presentes em tais horizontes, foram originadas por movimentos de expansão e contração. Pois, estes movimentos provocam um aumento nos poróides alongados, o que não foi observado no presente trabalho. 


\section{CONSIDERAÇÕES FINAIS}

Os resultados mostraram que os solos, da seqüência estudada, possuem de forma geral textura que varia de franco-argilo-arenosa a argilo-arenosa; estrutura grumosa nos horizontes superficiais, em blocos subangulares de grau fraco nos horizontes latossólicos; são dependentes da serrapinheira quanto à disponibilidade de nutrientes; possuem assembléia mineralógica simples (quartzo, feldspato, mica), cujos minerais estão em diferentes estágios de intemperismo.

Os estudos micromorfológicos dos horizontes prismáticos presentes nas trincheiras 13 e 4 , apresentaram fábricas birrefringentes estriada cruzada, granoestriada, poroestriada, que indicam que o material sofreu movimentos que contração e expansão. Estes horizontes são mais argilosos, compactos e possuem menor porosidade. Os resultados de análise de imagem comprovaram diminuição da porosidade nos horizontes prismáticos. 


\section{REFERÊNCIAS BIBLIOGRÁFICAS}

ABREU, C.A.; ABREU, M.F.; RAIJ, B.van; BATAGLIA, O.C.; ANDRADE, J.C. Extraction of boron from soil by microwave heating for ICP-AES determination. Communications in Soil Science and Plant Analysis, v.25, p.3321-3333, 1994.

AGUIAR, O.T. Flora fanerogâmica de um trecho da floresta densa secundária no Parque Estadual da Serra do Mar-Núcleo Cunha/Indaiá-SP. Revista do Instituto Florestal, v. 13, n. 1, p. 1-18, 2001.

ANIDO, N.M.R. (2002) Caracterização hidrológica de uma microbacia experimental visando identificar indicadores de monitoramento ambiental. Piracicaba, 69 p. Dissertação (Mestrado) - Escola Superior de Agricultura "Luiz de Queiroz", Universidade de São Paulo.

ARCOVA, F.C.S. (1996) Balanço hídrico, características do deflúvio e calibragem de duas microbacias hidrográficas na Serra do Mar, SP. Piracicaba, 130 p. Dissertação (Mestrado) - Escola Superior de Agricultura "Luiz de Queiroz", Universidade de São Paulo.

ARCOVA, F.C.S.; CICCO, V. Características do deflúvio de duas microbacias hidrográficas no Laboratório de Hidrologia Florestal Walter Emmerich, Cunha - SP. Revista do Instituto Florestal, v. 9, n. 2, p. 153-170, 1997.

ARCOVA, F.C.S.; CESAR, S. F.; CICCO, V. Qualidade da água em microbacias recobertas por floresta de Mata Atlântica, Cunha, SP. Revista do Instituto Florestal, v. 10, n. 2, p. 185-196, 1998.

BICUDO, D.C.; FORTI, M.C.; CARMO, C.F.; BOUROTTE, C.; BICUDO, C.E.M.; MELFI, A.J.; LUCAS, Y. A atmosfera, as águas superficiais $e$ os 
reservatórios no PEFI: caracterização química. In: BICUDO, D.C.; FORTI, M.C.; BICUDO, C.E.M. Parque Estadual das Fontes do Ipiranga: unidade de conservação que resiste à urbanização de Såo Paulo. São Paulo, Secretaria do Meio Ambiente do Estado de São Paulo. p. 161 - 200, 2002.

BOCQUIER G. Genèse et évolution de deux toposéquences de sols tropicaux du Tchad. Interprétation biogéodynamique, 1971, 350 p.Thèse, Univ. Strasbourg et Mémoires ORSTOM n ${ }^{\circ} 62$, Paris.

BOCQUIER, G.; MULLER, J.P.; BOULANGE, B. 1984. Les latérites: connaissances et perspectives actuelles sur les mecanismes de leur differenciation. In: LIVRE JUBILAIRE CINQUANTENAIRE AFES. Paris. p. 123-138.

BOULET, R. Toposéquences de sols tropicaux em Haute-Volta. Equilibre et desequilibre pédobioclimatique. Thése sci. Strasbourg et Mém: ORSTOM: 85,272 p., 1974.

BOULET, R.; CHAUVEL, A.; HUMBEL, F.X.; LUCAS, Y Analyse structurale et cartographie en pédologie. 1 - Prise en compte de l'organisation bidimensionnelle de la couverture pédologique: les étude de toposéquences et leurs principaux apports à la connaissance des sols. Cahiers ORSTOM, Séries Pédologie, v. XIX, n. 4, p. 309-321, 1982a.

BOULET, R.; HUMBEL, F.X.; LUCAS, Y Analyse structurale et cartographie en pédologie. II - Une méthode d'analyse prenant en compte l'organisation tridimensionnelle des couvertures pédologiques. Cahiers ORSTOM, Serries Pédologie, v. XIX, n. 4, p. 323-339, 1982b.

BOULET, R. Análise estrutural da cobertura pedológica e cartografia. In: XXI CONGRESSO BRASILEIRO DE CIÉNCIA DO SOLO, Campinas, julho 1987. A Responsabilidade Social da Ciência do Solo, Sociedade Brasileira de Ciência do Solo, Campinas. p.79-90. 1988.

BRASIL. Ministério da Agricultura. Centro Nacional de Ensino e Pesquisas Agronômicas. Serviço Nacional de Pesquisas Agronômicas. Comissão de Solos. (1960) Levantamento de reconhecimento dos solos do Estado de 
São Paulo: contribuição à carta de solos do Brasil. Rio de Janeiro, 634p. (Boletim, 12).

BREWER, R. Cutans: their definition, recognition, and interpretation. Journal of Soil Science, v. 11, n. 2, p. 280-293, 1960.

BULLOCK, P.; FEDEROFF, N.; JONGERIUS, A.;STOOPS, G.; TURSINA, T. Handbook for soil thin section description. Albrington, UK: Waine Research, $152 \mathrm{p}, 1985$.

BUOL, S.W. \& ESWARAN, H. The micromorphology of oxisols. In: DELGADO, M. (Ed) Micromorfologia de suelos. Proceeding of the fifth international working meeting on soil micromorphology. Granada: 1978. v. I, p. 325-347.

CARVALHO, W.A.; PANOSO, L.A.; PFEIFER, R.M.; ROSSI, M. Levantamento de reconhecimento dos solos do Parque Estadual da serra do Mar - Núcleo Cunha, SP (Bacia "D"). Revista do Instituto Florestal, v. 2, n. 2, p. 127-155, 1990.

CASTRO, S.S.; COOPER, M.; SANTOS, M.C.; VIDAL-TORRADO, P. Micromorfologia de solos:bases e aplicações. In: Nilton Curi; João José Marques; Luiz Roberto Guimarães Guilherme; José Maria de Lima; Alfredo Scheid Lopes; Victor Hugo Alvarez V. (Org.) Tópicos em Ciência do Solo. III ed. Viçosa, 2003, v. 3, p. 107-164.

CECON, K. Deposição de elementos traço em solo de floresta de Mata Atlântica via serapilheira. Campinas, 2003. 78p. Dissertação (Mestrado) - Instituto de Química, Universidade Estadual de Campinas.

CHAUVEL, A. Recherches sur la transformation des sols ferralitiques dans la zone tropicale à saisons contrastées. Travails et Documents ORSTOM, v.62, 532p., 1977.

CHAUVEL, A., SOUBLES, F., MELFI, A.J. Ferralitic soils from Brazil: formation and evolution of structure. Sciences Geol. Mém. 72, 37-46, 1983.

CICCO, V., ARCOVA, F.C.S.; CESAR, S.F.; CARVALHO, J.L.; FUJIEDA, M. Relações entre a precipitação e os escoamentos total, direto e de base em 
uma bacia hidrográfica experimental na região da Serra do Mar, Cunha SP. Revista do Instituto Florestal, v. 7, n. 1, p. 57-64, 1995.

COLLEUILLE H., 1993. Approches physique et morphologique de la dynamique structurale des sols. Application à l'étude de deux séquences pédologiques tropicales. 1994, 354. Thèse Doct., Univ. Paris VI e ORSTOM Editions.

COOPER, M. Influência das condições físico-hídricas nas transformações estruturais entre horizontes B latossólico e B textural sobre diabásio. (1999) Piracicaba, 130p. Tese (Doutorado) - Escola Superior de Agricultura "Luiz de Queiroz", Universidade de São Paulo.

DOMINGUES, E.N.; MATTOS, I.F.A.; FURIAN, S.M. Geomorfologia e cobertura vegetal atual da microbacia do Ribeiräo do Barracão no Núcleo Cunha, Parque Estadual da Serra do Mar - SP. Revista do Instituto Florestal, v. 13, n. 2 , p. 189-200, 2001.

EMBRAPA - EMPRESA BRASILEIRA DE PESQUISA AGROPECUÁRIA. (1999) Serviço de Produção de Informação. Sistema Brasileiro de Classificação de Solos. Brasília.

ESCHENBRENNER, V. Contribution des termites à la micro-agrégation des sols tropicaux. Cahiers ORSTOM, Séries Pédologie, v. XXII, n. 4, p. 397-408, 1986.

FERREIRA, M.M.; FERNADES, B.; CURI, N. Influência da mineralogia da fração argila nas propriedades físicas de Latossolos da região Sudeste do Brasil. Revista Brasileira de Ciência do Solo, v.23, p. 515-524, 1999.

FOX, R.L.; HUE, N.V.; PARRA, A.J. A turbidimetric method for determining phosphate-extractable sulfates in tropical soils. Communications in Soil Science and Plant Analysis, v.18, p.343-357, 1987.

FUJIEDA, M.; TETSUYA, K.; CICCO, V.; CALVARCHO, J.L. Hydrological processes at two subtropical forest catchments: the Serra do Mar, São Paulo, Brazil. Journal of Hydrology, v.196, p.26-46, 1997. 
FURIAN, S.M.; PFEIFER, R.M. Levantamento de reconhecimento de meio físico do Núcleo de Cunna, SP. Boletim Técnico do Instituto Florestal, v.40, n.2, p.183-193, 1986.

FURIAN, S.; BARBIÉRO, L.; BOULET, R. Organization of the soil mantle in tropical southeast Brazil (Serra do Mar) in relation to landslides process. Catena, v.38, p.65-83, 1999.

FURIAN, S.; BARBIERO, L.; BOULET, R.; CURMI, P.; GRIMALDI, M.; GRIMALDI, C. Distribution and dynamics of gibbsite and kaolinite in an oxisol of Serra do Mar, southeastern Brazil. Geoderma, v.106, p.93-100, 2002.

HALLAIRE, V. \& COINTEPAS, J.P.,. Caractérisation de la macroporosité d'un sol de verger par analyse d'image. Agronomie, v.13,p.155-164, 1993.

HALLAIRE, V.; CURMI, P. (1994) Image analysis of pore space morphology in soil sections, in relation to water movement. In: A.J. Ringrose-Voase and G.S. Humphreys (Editors), Soil Micromorphology: Studies in Management and Genesis. Proc. IX Int. Working Meeting on Soil Micromorphology. Developments in Soil Science, 22. Elsevier. Amsterdam, pp. 559-567.

KARATHANASIS, A.D.; ADAMS, F.; HAJEK, B.F. Stability relationships in kaolinite, gibbsite and Al-hidroxyinterlayered vermivulite soil systems. Soil Science Society American Journal, v.47, p.1247-1251, 1983.

KRETZSCHMAR, R.; ROBARGE, W.P.; AMOOZEGAR, A.; VEPRASKAS, M.J. Biotite alteration to halloysite and kaolinite in soil-saprolite profiles developed from mica schist and granite gneiss. Geoderma, v.75, p.155-170, 1997.

KUBIENA, W.L. Micropedology. lowa: Collegiate Press Inc., 1938.

LEITÃO FILHO, H. F. Aspectos taxonômicos das florestas do Estado de São Paulo. In: CONGRESSO NACIONAL SOBRE ESSÊNCIAS NATIVAS, 1982. Anais. São Paulo, Edição Especial, v.1, p.197-206, 1982.

LEMOS, R.C.; SANTOS, R.D. Manual de descrição e coleta de solo no campo. Campinas: SBCS/SNLCS, 1984, 46p. 
LINDSAY, W.L. Chemical equilibria in soils. New York: John Wiley, 1979. 449p.

LINDSAY, W.L.; NORVELL, W.A. Development of a DTPA soil test for zinc, iron, manganese, and copper. Soil Science Society of America Journal, v.42, p.421-428, 1978.

MERMUT, A.R. Introduction to soil micromorphology. Saskatoon: University of Saskatchewan, Department of Soil Science, 1992, 115p.

MIKLOS, A.A. DE W. Biodynamique d'une coverture pédologique dans la région de Botucatú, Brésil, 438p. 1992. Tese de Doutoramento. Université de Paris VI, France. Vols. I e II.

MIKLOS, A.A. DE W. Funcionamento biodinâmico da paisagem. Ciência \& Ambiente, v.IV, n.6, p.75-83. 1993.

MIYAZAWA, M.; PAVAN, M.A.; CALEGARI, A. Efeito de material vegetal na acidez do solo. Revista Brasileira de Ciencia do Solo, v.17, p.411-416, 1993.

MODENESI, M.C., TOLEDO, M.C.M., Weathering and the formation of hillslope deposits in the tropical highlands of Itatiaia, southeastern Brazil. Catena v.27, p.81-103, 1996.

MORAN, C.J.; KOPPI, A.J.; MURPHY, B.W.\& MCBRATNEY A.B. Comparison of the macropore structure of a sandy loam surface soil horizon subjected to two tillage treatments. Soil Use and Management, v.4, p.96-102, 1988.

MÜLLER, J. P. Microstructuration des structichrons rouges ferralitiques, à l'amont des modelés convexes (Centre Cameroun). Aspects morphologiques. Cahiers ORSTOM Séries Pédologie, v.15, p.239-258, 1977.

MÜLLER, J. P. Sequence of vertical evolution in the micro-organisation of loose ferrallitic materials in the Cameroons. In: BULLOCK, P; MURPHY, C. P. Soil Micromorphology. International Working Meeting Soil Micromorphology. Proceeding. London: London A. B. Academic Publishers, p.1-10, 1981. 
MULLER, J.P.; BOCQUIER, G. Dissolution of kaolinites and accumulation of iron oxides in lateritic-ferruginous nodules: mineralógical and microstructural transformation. Geoderma, v.137, p.113-136, 1986.

MURPHY, C.P.; BULLOCK, P.. \& TURNER, R.H., The measurement and characterization of voids in soil thin sections by image analysis. Part 1. Principles and techniques. Journal of Soil Science, v.28, p.498-508, $1977 \mathrm{a}$.

MURPHY, C.P.; BULLOCK, P. \& BISWELL, K.J., The measurement and characterization of voids in soil thin sections by image analysis. Part II. Applications. Journal of Soil Science, v.28, p.509-518, $1977 \mathrm{~b}$.

NELSON, D.W.; SOMMERS, L.E. Total carbon, organic carbon, and organic matter. In: SPARKS, D.L. (Ed.). Methods of soil analysis: chemical methods. pt. 3. Madison: Soil Science Society of America/American Society of Agronomy, 1996. p.961-1010.

NETTLETON, W. D.; FLACH, K. W.; BRASCHER, B. R. Argillic horizons without clay skins. Soil Science Society America Proceedings, v.33, p.121-125, 1969.

NOVAIS, R.F.; SMITH, T.J. Fósforo em solo e planta em condições tropicais. Viçosa: UFV - Departamento de Solos, 1999. 399p.

PEDRO, G.; CHAUVEL, A. \& MELFI, A. Recherces sur la constitution des Terra Roxa Estruturada du Brésil. Annalles Agronomie, v.27, n.3, p.265-294. 1976.

PEDRO, G. Géochimie, mineralogie et organisation des sols. Aspects coordonnés des problèmes pédogenétiques. Cahiers ORSTOM Séries Pédologie, v.23, n.3, p.169-186, 1987.

POGGIANI, F.; SCHUMACHER, M.V. Ciclagem de nutrientes em florestas nativas. In: GONÇALVES, J.L.M; BENEDETTI, V. Piracicaba: IPEF, 2000, p.288-308.

PRANDINI, F.L.; ÁVILA, I.G.; LEITE, C.A.G.; SANTOS, M.T.N. (1982) Uso e ocupação do solo no Alto Paraíba (I): contribuição ao conhecimento de sua 
evolução. In: CONGRESSO NACIONAL SOBRE ESSÉNCIAS NATIVAS, 1982. Anais. São Paulo, UNIPRESS, v.40, p.1929-1035.

RAIJ, B.van. A capacidade de troca de cátions das fraçס̃es orgânica e mineral em solos. Bragantia, v.28, p.85-112, 1969.

RAIJ, B.van. Fertilidade do solo e adubação. Piracicaba: Potafos, 1991, 343p.

RINGROASE-VOASE, A.J. Micromorphology of soil structure: description, quantification, application. Australia Journal of Soil Research, v.29, p.777813, 1991.

RUELLAN, A., DOSSO, M. \& FRITSCH, E. L'analyse structurale de la couverture pédologique. Science du Sol, v.27, n.4, p.319-334, 1989.

SANTOS, M.C.D.; MERMUT, A.R.; RIBEIRO, M.R. Submicroscopy of clay microagregates in an oxisol from Pernambuco, Brazil. Soil Science Society América Jornal, v.53, p.1895-1901, 1989.

SÃo PAULO (Estado) Instituto de Pesquisas Tecnológicas. Mapa geológico do Estado de São Paulo. São Paulo, IPT/PRÓ-Minério, 1981a. (Escala 1: $500.000)$.

SÃO PAULO (Estado). Instituto de Pesquisas Tecnológicas. Mapa geomorfológico do Estado de São Paulo. São Paulo, IPT/PRÓ-Minério, $1981 \mathrm{~b}$.

SILVA, A.C. \& VIDAL-TORRADO, P. Gênese dos latossolos húmicos e sua relação com a evolução da paisagem numa área cratônica do sul de Minas Gerais. Revista Brasileira de Ciência do Solo, v.23, p.329-341, 1999.

STEVENSON, F.J. Humus chemistry: genesis, composition, reactions. 2ed. New York: John Wiley \& Sons, 1995, 496p.

STOOPS, G.; JONGERIUS, A. Proposal for a micromorphological classification in soil materials: I. A classification of the related distributions of coarse and fine particles. Geoderma, v.13, p.189-200, 1975.

STOOPS, G. Micromorphology of the oxic horizon. In: PROCEEDING 6th INTERNACIONAL WORKSHOP MEETING SOIL MICROMORPHOLOGY, 
1981, London. Soil micromorphology. Berkhamsted, U. K.: A. B. Academic publlishers, v.2, p. 419-440, 1983.

STOOPS, G. \& BUOL, S.W. Micromorphology of oxisols. In: SOIL MICROMORPHOLOGY AND SOIL CLASSIFICATION. Proceedings of a symposium sponsored by Divisions S-5 and S-9 of the Soil Science Society of America, Anaheim. SSSA, Madison. 1985. 105-119p.

TAN, K.H.; B.F. HAJEK; I. BARSHAD. (1986) Thermal analysis techniques. $p$. 151-183. In A. lute (ed.) Methods of soil analysis. Part 1. Physical and mineralogical properties. 2nd ed. Agronomy 9:151-183.

TAYLOR, R.G.; HOWARD, K.W.F. Lithological evidence for the evolution of weathered mantles in Uganda y tectonically controlled cycles of weathering and stripping. Catena v.35, p.65-94, 1999.

TOLEDO-GROKE, M.C.M. (1986) Intemperismo das rochas mineralizadas em cobre do salobro 3A, Serra dos Carajás. Mecanismos de alteração dos minerais primários e localização do cobre nos produtos secundários. São Paulo, 173p. Tese (Doutorado) - Instituto de Geociências, Universidade de São Paulo.

VIDAL-TORRADO, P.; LEPSCH, I.L. Relaçð̃es material de origem / solo e pedogênese em uma seqüência de solos predominantemente argilosos e latossólicos sobre psamitos na Depressão Periférica Paulista. Revista Brasileira de Ciencia do Solo, v.23, p.357-369, 1999.

VIDAL-TORRADO, P.; LEPSCH, I.L.; COOPER, M. Pedogênese em uma seqüência Latossolo-Podzólico na borda de um platô na Depressão Periférica Paulista. Revista Brasileira de Ciência do Solo, v.23, p.909-921, 1999.

VITOUSEK, P.M.; SANFORD JR., R.L. Nutrient cycling in moist tropical forest. Ann. Rev. Ecol. Syst., v.17, p.137-167, 1986.

WHITTIG, L.D.; ALLARDICE, W.R. (1986) X-ray diffraction techniques. In: A.K. Klute (Editor), Methods of Soil Analysis. Part 1.2nd. ed. Agron. Monogr., 9. ASA/SSSA, Madison, WI, pp. 331-362. 